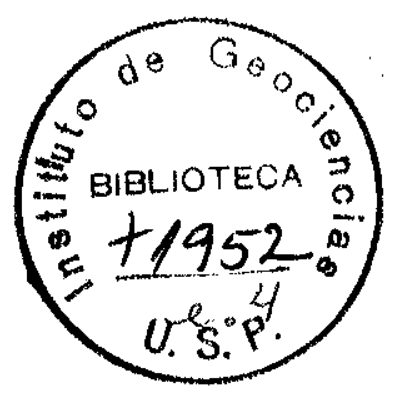

\title{
O LiNEAMENTO de alÉm PARAíba NA ÁREA de TRÊS RIOS (RJ)
}

\author{
GINALDO A. DA C. CAMPANHA
}

Dissertaçăo de Mestrado epresentada ao instituto de Geoclenclas da Universidade de Sáo Paulo. Orlentador!

Prof. Dr. Fernando Flávlo Marques de Almelda

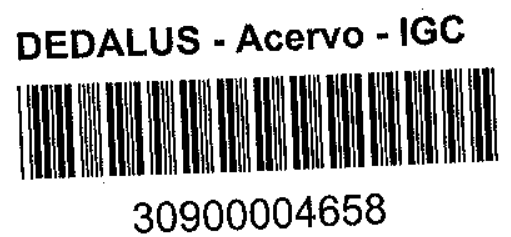




\section{INDICE}

Pãgina

1 - INTRODUÇÃO

1.1 - Problemas, Objetivos e Abordagem

1.2 - Metodologia 3

1.3 - Nomenclatura de Rochas Cataclästicas

1.4 - Nomenclatura de Migmatitos

í.5 - Rochas de Fäcies Granulito

2 - TRABALHOS ANTERIORES

2.1 - Sistema de Falhamentos Transcorrentes da Região Sudeste

2.2 - Geologia da Região do Lineamento de Alēm Paraĩba

2.3 - Geologia da Folha de Três Rios

3 - AREA DE TRES RIOS

3.1 - Localização da Area Escolhida e Traba lhos Realizados

3.2 - Estruturação Geolōgica

3.3 - Condicionantes Geolögicos da Fisiografia

3.4 - Litologias

3.4.1 - Rochas Blastomiloniticas

3.4 .2 - Migmatitos

3.4.3 - Gnaisses Bandados

3.4:4 - Quartzitos

3.4.5 - Rochas Granuliticas

3.4 .6 - Rochas Carbonaticas e Calcossili catadas 
Păgina

$3.4 .7-$ Anfibolitos 42

3.4 .8 - Rochas Intrusivas 42

3.4 .9 - Depösitos Aluvionares 43

$3.5-$ Estruturas 44

3.5 .1 - Foliações 44

3.5 .2 - Lineações 46

3.5 .3 - Dobras 49

3.5 .4 - Estruturas Disruptivas $\quad 55$

3.6 - Migmatização 60

3.7 - Evolução Estrutural e Metamörfica 62

3.8 - Anälise dos Dados Geocronolögicos
Existentes

4 - INTEGRAÇAO REGIONAL E EVOLUÇĀO GEOLOGICA 77

5 - CONCLUSOES $\quad 86$

6 - AGRADECIMENTOS $\quad 89$

7 - REFERENCIAS BIBLIOGRÁFICAS 92

CONTEM 2 TABELAS, 10 FIGURAS E 50 FOTOGRAFIAS

ANEXOS :

Anexo 1 - Mapeamentos sistemäticos na região do Lineamento de Alēm Paraíba

Anexo 2 - Mapa de pontos de afloramentos

Anexo 3 - Esboço e perfis geológicos - Area de Três Rios

Anexo 4 - Mapa de Iineamentos de imagens Landsat-1 


\section{1 - INTRODUÇÃO}

o estudo e caracterização sistemāticos de estrutú ras de falhamento transcorrente de âmbito regional é relati vamente recente no Brasil. Em duas regiões estes encontram-se melhor estudados. No Nordeste, na Região de Dobramentos Caririana. No sudeste, no que HASUI et al. (1975) denomina ram de "Zona de Transcorrência são Paulo", e BRAUN "Faixa Rüpt1l do Rio Paraíba do Sul". No Nordeste KEGEL (1961) e EBERT (1962) identificaram um sistema de IIneamen tos que secciona as estruturas regionals. Na região Sudeste, ALMEIDA (1955) e HENNIES et al. (1967) caracterizam pela pri meira vez a ocorrência de falhamentos transcorrentes maiores na região. Nas duas regiões atualmente configura-se um qua dro de sistemas de falhamentos ou lineamentos, que condició nam uma estruturação geológica regional em blocos tectônicos.

Jâ hă algum tempo, diversos autores vêm propondo ser a crosta continental recortada por redes de lineamentos ou falhamentos maiores, que podem afetar toda sua espessura e promover uma tal estruturação em blocos. Estas estruturas não apenas separam blocos distintos, como tambēm em geral apresentam uma estruturação e evolução complexas. Pođem apresentar évidências de terem sofrido movimentos e deforma ções com diferentes caracteres no decorrer do tempo, e uma evolução polifásica que pode remontar à Àrqueano. Portanto, sua caracterização geolōgica e evolutiva é essenclal para a compreensão da compartimentação e histōria geológica de uma dada região (ver DE SITTER, 1956; PEIVE, 1960; BELOUSSOV, 1962; NEVSKIY, 1965; NGUYEN DIN'KAT, 1972; WATSON, 1973; MCCONNELL, 1973, etc.) .

ALMEIDA, HASUI \& CARNETRO (1975) identiflcam e des crevem o Lineamento de Além Paraíba, no Estado do Rio de Já neiro. Observam que este se constitui numa faixa de blastó milonitos que corta obliquamente as estruturas da "série Pá raíba-Desengano" (ROSIER, 1965), tida como de idade transama 
zônica, remobilizada durante o Ciclo Brasiliano (DELHAL et al., 1969 e CORDANI et al., 1973). Mostram que sua evolução não fol simples em termos de movimentos e recristalização, ten do sido ativa durante o Prë-Cambriano superior, e tendo pro vavelmente suas ültimas fases de movimentação ao final do Ciclo Brasiliano, jā durante o Paleozöico.

Esta estrutura apresenta expressividade morfológ壬 ca regional, aparentando também ter grande importância na compartimentação geolōgica da região. Possul característi cas que permitem reconstituir pelo menos em parte sua histō ria mals antiga.

\section{1 - Problemas, objetivos e Abordagem}

Diversos aspectos referentes à rede de falhamentos transcorrentes da região sudeste do Brasil ainda não foram elucidados: Dentre eles destacam-se os segulintes:

a) determinação da totalidade da rede de falhamen tos transcorrentes;

b) determinação da distribulção espacial e rela ções entre unidades tais como os Grupos Paraíba, Amparo, Açun gui, Serra dos Orgãos, e Formações Barbacena e Juiz de Fora, pelo menos em parte delimitadas pelos falhamentos;

c) determinação da sequência evolutiva de cada uma dessas unidades (apenas parcialmente conhecida em algumais re giões), ou de outras unidades ou blocos tectônticos a serem reconhecidos;

d) determinação da sequêncla evolutiva dos falhạ mentos maiores; a partır das etapas flnais do Clclo Brasí liano, esta sequência está razoavelmente determinada, como o foi orlginalmente nos trabalhos de ALMEIDA (1955) e. de HENNIES et al. (1967), estando relacionada aos estádios de transição e reativação da Plataforma Brasileira (ALMEIDA, 1969); no entanto, sua histöria mais antiga, assim como suas rela ções com as fases princlpals de metamorfismo e deformação do 
Clclo Brasiliano, são desconhecidas.

A reglão afetada pelo Lineamento de Alẻm paraíba oferece condições propicias para tentativas de resolução de alguns desses problemas. o presente trabalho tem especif1 camente como objetivos a caracterização geolöglco-estrutural dessa feição e a determinação de sua sequência evolutiva (fa ses de movimento e recristalização). Como estratëgla de abor dagem do problema, realizou-se um reconhecimento preliminar da região, selecionando-se então uma ärea relativamente pe quena para os trabalhos de detalhe, abrangendo a zona de ro chas blastomiloniticas e porções imediatamente contiguas dos blocos adjacentes, não afetados pela deformação intensa. Es ta ärea fol mapeada na escala 1:50.000, tendo sido realiza dos estudos de malor detalhe nos pontos mais interessantes.

\section{2 - Metodologia}

Anālise estrutural qualitativa ao nivel de aflora mento (escala mesoscópica) e análise de texturas microscópí cas foram os métodos essenclals adotados neste trabalho. Como referências metodológicas bāsicas podem ser ciitadas as obras de TURNER \& WEISS (1963), HOBBS et al. (1976) e SPRY (1969). Os artigos de CHRISTIE $(1960,1963)$ e de REED \& BRYANT (1964) podem ser considerados como exemplos de trabalhos semelhan tes. O enfoque bāsico foi realizar anālise geométrica das estruturas da ārea mapeada em detalhe ou seja, determinar a configuração e arranjos espaciałs destas, e na medida do pos sível, sua sequência de eventos, etapa necessāría para .. in terpretações sobre a história deformactonal e de esforços dá área. Não se adotou procedimentos de anālise estatistica de petrofabric. Diagramas de distribulção estatística de estru turas mesoscópicas, como foliações, lineações, eixos de dô bras e juntas, foram feitos com o intuito de mostrar os pa drões dominantes, antes do que realizar anāilises estatisti cas elaboradas. Justiflca-se tal procedimento pelo fato de se estar dando uma abórdagem preliminar ao problema, neces. 
sāria para análises quantitativas posteriores.

Para a seleção da área de detalhe, examinou-se os trabalhos anteriores sobre a região,mapas topográficos e ima gens multiespectrais de satëlite. Percorreu-se a região dó Lineamento de Alēm Paraíba onde este foi originalmente defi nido, e executou-se alguns caminhamentos geológicos prelimí nares, transversais à Zona de Rochas Blastomiloníticas, atrâ vés das estradas principais da região.

Na ärea de detalhe escolhida, foi adotado o proce dimento de primeiramente realizar no campo caminhamentos transversais às estruturas, procurando-se correlacionar e in tegrar as observações pontuais, estabelecendo-se as relações estruturais e variações litológicas entre os tipos observa dos. Posteriormente, percorreu-se a maior parte das estrá das e caminhos restantes, procurando-se delimitar as unida des observadas. A cada etapa de trabalhos de campo, foi fei ta foto-interpretação, anālise e correlação dos dados obti dos.

No mapa geológico final, indicou-se como contatos definidos aqueles que ocorrem de maneira brusca na - escala de mapeamento $(1: 50.000)$, entre unidades bem caracterizadas e com bom controle de campo. Como contatos aproximados aque les em que a caracterização das unidades e/ou contatos não foi precisa, em função dos dados de campo disponiveis, sendo delimitados por foto-interpretação. Contatos transicionais foram traçados entre unidades que apresentam gradação con tinua entre si, com passagem suave na escala de mapeamento, sendo o contato traçado, se possivel, na região mediana da faixa de transição.

Em escala de afloramento observou-se litologias, texturas e estruturas, com suas variações espaciais. Procu rou-se determinar sequências de eventos sobrepostos, através de anälise estrutural qualitativa.

Estruturas em escala macroscópica, como sinformas 
e antiformas, foram inferidas com base em evidências em esca la de afloramento.

o trabalho com seções delgadas, em escala microscó pica, foi essencial. Procurou-se não só determinar mineralōo giaș e paragêneses, mas tambēm se deu ênfase ao estudo das texturas e microestruturas, em nivel qualitativo, procurando-se determinar sequências de eventos de cristalização e de formação. Para este trabalho, alēm do microscópio petrogrā fico usual, a utilização de lupa com polarizadores foi de grande valia, pois permitiu a observação de um campo maior nas seções delgadas, necessário para o reconhecimento e cor relação das texturas e microestruturas. A confecção de se ções em vários cortes perpendiculares entre si numa mesma amostra, assim como a de seções delgadas como ãreas majores que as usuais, foram tambëm de grande ajuda.

Definido o quadro geológico da ārea, foram revis tas as interpretações dos dados geocronológicos existentes na literatura. Apenas uma nova datação, k/Ar em biotita, foi realizada, de amostra de dique de pegmatito que corta trans versalmente a Zona de Rochas Blastomiloniticas.

\section{3 - Nomenclatura de Rochas Cataclästicas}

Não existe no momento nenhuma classificação para rochas cataclästicas aceita consensualmente, assim como não existe acordo sobre a definição de termos como"cataclase" ou "milonito" e sobre os processos que geram este tipo de ro chas.

Historicamente a nomenclatura dessas rochas está relacionada a processos rúpteis (trituramento, esmigalhamento, fraturamento, ruptura de rochas). No entanto, desde o traba lho original de LAPWORTH (1885), o qual definiu o termo "mi lonito", reconhece-se que processos de recristalização e de formação dúctil podem atuar em grau variável nesse tipo de rochas. Tambëm não se pode dizer simplesmente que são atri. 
buiveis a processos puramente destrutivos, uma vez que origi nam rochas com texturas e estruturas definidas, com grau de "ordenação" por vezes mais alto que as prōprias rochas origi nais.

Trabalhos relativamente recentes como os de CHRISTIE (1960) e HIGGINS (1971) tentaram ordenar a ampla e confusa literatura existente sobre rochas cataclāsticas lou miloni ticas, em senso amplo), revisando a literatura existente. En tre outros autores que organizaram classificações sintēticas e abrangentes para este tipo de rochas, pode-se citar WATERS \& CAMPBELL (1935) e SPRY (1969).

Adotaram-se aqui critérios e classificação de HIGGINS (1971), sintetizađos na Tabela 1. Esse autor propõe - termo rocha cataclástica como designativo geral para todas rochas formadas por cataclase, entendida como o processo pe lo qual as rochas são quebradas e granuladas devido aos es forços e movimentos durante o falhamento. Restringe o uso do termo milonito para as rochas com as caracteristicas enu meradas por LAPWORTH (1885).

Propõe uma classificação para rochas cataclāsticas utilizando critērios múltiplos, a saber: a) porcentagem de volume de porfiroclastos (Exagmentos maiores de minerais ou agregados minerais de origem cataclástica);b) tamanho da maior parte dos porfiroclastos; c) presença ou ausêncla de coesão primāria (coesão singenética, não devida a cimentação posterior); d) textura dominante (cataclāstica ou de recris talização); e) presença ou ausência de foliação cataclāstica; (ver Tabela 1). Existem transições entre tođos os tipos, sen do os limites entre eles arbitrários. Textura, inclusive grau de recristalização/neomineralização, é a principal base para a classificação. o tamanho e a porcentagem em volume aproximados dos porfiroclastos, comparados com fotomicrogra fias padrões, são os únicos parâmetros quantitativos utilizâ dos.

Um problema relacionado à classificação de HIGGINS 
(1971) è que este autor considera que a cataclase e a recris talização ocorram simultaneamente, dentro de uma mesma fase. Então rochas da sequência protomilonito-milonito-ultramiloni to, recristalizadas posteriormente à sua cataclase, não deve riam ser denominadas blastomilonitos ou milonito-gnaisses, mas sim por exemplo, milonitos metamorfizados. E tambëm implica ria que cataclase e recristalização fossem sempre fenômenos perfeitamente distinguiveis nessas rochas, o que de acordo com trabalhos mals recentes, pode nem sempre ser correto(ver BELL \& ETHERIDGE, 1973; TULLIS et al., 1973; HOBBS et al.。 1976)

Porëm, tais considerações de caräter genético dem ser a princípio deixadas de lado, e a classificação de HIGGINS utilizada segundo critérios puramente descritivos. Como por exemplo, definições como a que se segue, (de miloni to em senso amplo, ou seja, equivalente a todas rochas cata clásticas coesivas e foliadas) poderiam ser utilizadas: "Um milonito è uma rocha foliada, comumente lineada e contendo megacristais, a qual ocorre em zonas planares e estreitas de intensa deformação. E frequentemente de granulação mais fi na que as rochas circundantes, nas quais grada" (BELL \& ETHERIDGE, 1973, pāg. 347).

Todas as rochas cataclästicas observadas na ärea estudada correspondem a blastomilonitos ou milonito-gnaisses, na acepção de HIGGINS (1971), com considerável grau de re cristalização. Por uma questão de brevidade, adota-se aqui a denominação genērica de rochas blastomiloniticas quando se quiser referir indiferenciadamente a rochas cataclásticas com texturas de recristalização dominantes.

Para caracterizar com certeza rochas blastomiloni ticas, foram necessārias quase sempre seções delgadas. No en tanto, quando em escala de afloramento as felções cataclās ticas são muito claras, ou quando se trata de uma faixa já caracterizada como constituída desse tipo de rochas, a dis tinção entre blastomilonitos e milonito-gnaisses pode ser 
TABEIA 1

CIASSIFICAÇÃO DE ROCHAS CATACLASTIICAS

(HIGGINS, 1971)

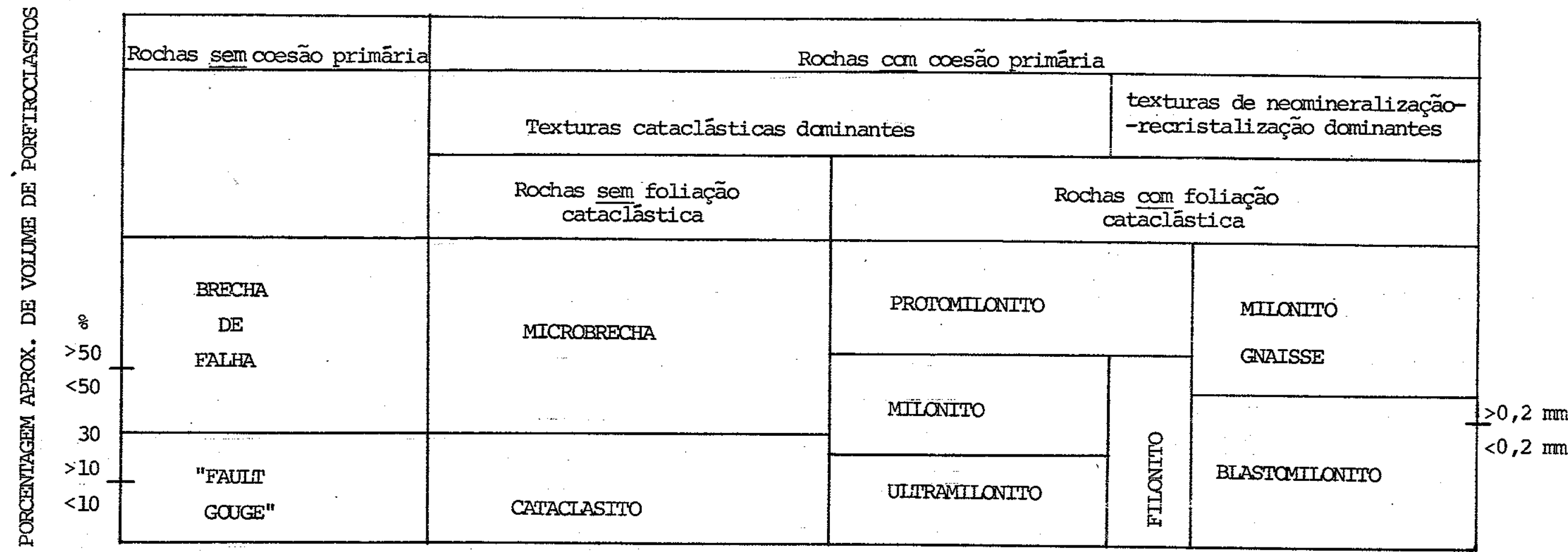

Termos como porfiroclástico, protoclästico, diafitorítico, pseudotaquilítico, filiztico, etc., são usados camo sufixos. adjetivantes.

Todas as rochas são gradacionais entre si 
feita macxoscopicamente. Como a variação entre estes dois tipos pode ser contínua, e ocorrem faixas alternadas deles nas mais variadas escalas, no mapeamento em escala 1:50.000 foram separadas falxas segundo critério de pređominância cla ra de um tipo ou de outro.

\section{4 - Nomenclatura de Migmatitos}

Para a classificação das rochas dos blocos adjacen tes adotou-se a classificação de migmatitos de MEHNERT (1968), além dos critërios petrográficos mais usuais, como os indica dos em WILLIANS et $a$. (1970). A classificação de MEHNERT foi utilizada para os trabalhos de campo, adotando-se critê rios puramente descritivos, conforme nos Capitulos 1 e 2 da referida obra. Alguns critérios para anālise de texturas mi croscōpicas foram utilizados segundo o Capítulo 3 , e também algumas definições contidas no Apêndice:

Os seguintes termos foram mais utilizados, com as definições do autor citado:

Migmatito: "Numa forma preliminar para uso prático no campo a seguinte definição pode ser utilizada: um migma tito é uma rocha composta megascopicamente de duas ou mais partes petrograficamente diferentes, uma das quais è a rocha regional num maior ou menor estāgio metamórfico, e a outra è de aparência pegmatitica, aplitica, granitica ou geralmen te, plutônica" (MEHNERT, 1968, pág. 8).

"Em migmatitos as seguintes partes podem ser geral mente distinguidas:

(1) o paleossoma, 1.ē., a rocha original ina1tera da ou ligeiramente transformada;

(2) o neossoma, $1 . \grave{e}$., a porção de rocha neoformada. Aqui novamente dois tipos de rocha podem em regra ser distin guidos, ou seja:

(a) o leucossoma contendo mais minerais claros 
(quartzo e/ou feldspato) com relação ao paleossoma;

(b) o melanossoma contendo principalmente minerais escuros (máficos), tais como biotita, hornblenda, cordierita. e outros".

(Op.cit., pägs 7 e 8).

Gnaisse: "Rocha metamórfica exibindo estrutura pa ralela (lineação, foliação, xistosidade), contendo mais que 20\% em feldspato".

(Op.cit., päg. 354).

Granito: "Rocha fanerítica, cristalina, maciça,cons tituída de quartzo, feldspato potāssico e plagioclāsio sōdí co (tipicamente oligoclásio) em quantidades aproximadamente iguais, e geralmente uma pequena quantidade $(5-10 \%)$ de mine rais mäficos (biotita, hornblenda e outros)".

(Op.cit., päg. 354).

Granitōide: "Termo de campo para um conjunto de ro chas de composição e texturas semelhantes a granito".

(Op.cit., pág. 354).

Estromatito: "Migmatito com estrutura bandada".

(Op.cit., päg. 357).

Agmatito: "Migmatito com estrutura semelhante a brecha".

(Op.cit., pāg. 353).

Nebulito: "Migmatito com estruturas reliquiares di fusas de rochas pré-existentes".

(Op.cit., pāg. 354).

"Chorismite": "Rocha megascopicamente composta a qual consiste de duas ou mais partes petrograficamente dife rentes de origem duvidosa ou incerta".

(Op.cit., pāg. 354) .

"Oftalmito": "Chorismite caracterizado por augens (e.g., feldspatos) ou agregados lenticulares de minerais neó 
formados " .

$$
\text { (Op.cit., päg. 356) . }
$$

Usaremos aqui o termo gnaisse bandado para rochas gnáissicas com estrutura plano-paralela composta unicamente de bandas com texturas metamórficas. Difere portanto da de finição de migmatito de MEHNERT e aproxima-se de sua defini ção de "chorismite". Tambēm não é utilizado aqui com o sen tido desse mesmo autor citado, de um gnaisse com estrutura bandada ortunda de acamamento reliquiar.

As estruturas migmatiticas relacionadas acima fo ram comumente encontradas, embora localmente outros tipos descritos por MEHNERT (1968) pudessem ser encontrados. Como frequentemente mais de um tipo de estrutura migmatitica é ob servavelel num mesmo local e sendo transicionais os contatos entre os diversos tipos, adotaram-se critērios de mapeamen to em função dos tipos predominantes.

Foram tambēm observados, em värias escalas, corpos de "resisters", ou sejam rochas refratārias à migmatização, como anfibolitos, quartzitos e rochas calcossilicatadas.

\section{5 - Rochas de Fäcies Granulito}

Não foi adotada nenhuma classificação especial pa ra rochas pertencentes à fácies granulito. Como tais, foram consideradas aquelas rochas com associações mineralögicas em equilíbrio contendo hiperstênio (equivalente à definição de "zona regional de hiperstênio" do grau forte de metamorfismo, de WINKLER, 1977). Foram eventualmente denominadas de "gra nulitos bāsicos" rochas dessa fácies com elevada porcentagem de pịroxênios e anfibōlios. Não foram denominadas de granu litos aquelas rochas com texturas de deformação "predominan tes, como as miloniticas, "flaser" e blastomiloniticas, com quartzo planar (discóide) como classicamente é feito, desde a definição original desse termo na saxônia. Isto pelo fato 
de representarem na ärea associações mineralōgicas em desi quilibrio, com as paragênese dos porfiroclastos deformados e da matriz mais fina recristalizada, pertencentes a diferen tes fácies metamörficas. 


\section{2 - TRABALHOS ANTERIORES}

Para melhor situar o problema em questão, foi fei ta uma revisão dos trabalhos de cunho geológico jā realizá dos sobre três aspectos:

1) Sistema de falhamentos transcorrentes da Região

Sudeste - englobando os trabalhos realizados sobre essas es truturas nos Estados de São Paulo, Rio de Janeiro e Sudeste de Minas Gerais.

2) Geologia da região do Lineamento de Alëm Parai ba - englobando os principais trabalhos de cunho geológico realizados em torno da região em que esta estrutura foi ori ginalmente definida, englobando assim toda região interior do Estado do Rio de Janeiro e a porção adjacente do Estado de Minas Gerais.

3) Geologia da Folha de Três Rios - RJ - Foi dedí cada atenção especial a esta área por ter sido escolhida pá ra os trabalhos de detalhe.

\section{1 - Sistema de Falhamentos Transcorrentes da Região Sudeste}

- Pré-Cambriano da Região Sudeste do pais é recor tado por uma rede de falhamentos transcorrentes, que aden tra os Estados do Rio de Janeiro, são Paulo, Paraná e Sudes te de Minas Gerais, denominada de "zona de Transcorrência são Paulo" por HASUI et al. (1975) e de "Faixa Rúptil do Rio Pá raíba do Sul", por BRAUN (1972). Para SW, este sistema de falhamentos mergulha sob a Bacia do parană, e para NE sob o oceano Atlântico. Os falhamentos que o compõe podem possuir extensões de até centenas de quilômetros, e larguras da or dem de até centenas ou mesmo milhares de metros, delimitados por vārios tipos de rochas cataclásticas. o movimento predo minante é transcorrente subhorizontal, apresentando portanto 
pequeno rejeito vertical. Foram ativos pelo menos no final do Ciclo Brasiliano, havendo algumas evidências de que pos sam ser ainda mals antigos. São de grande importância para a compreensão da geologia regional, pols promovem uma estru turação geológica da região em blocos de falha, delimitados pelos falhamentos transcorrentes, com identidades litolögi cas, metamörficas, estruturais, estratigräficas e geocrono lógicas próprias.

A evolução pōs-brasiliana desses falhamentos está relacionada aos estádios de transição e reativação da plata forma Brasileira (Sul-Americana), conforme definidos por ALMEIDA (1969). Particularmente na região em foco evoluiu no Mesozóico e Cenozóico um Sistema de "Rifts", denominado Sistema "Rift" da Serra do Mar (ALMEIDA, 1976).

Os movimentos verticais que deram origem às fei Ções morfológicas e às baclas tafrogênicas deste Sistema de "Rifts" foram acompanhados por intenso magmatismo bāsłco e alcalino. Sua evolução fol fortemente condicionada pela re de de falhamentos transcorrentes estabelecida ao final do Brasiliano, atravēs de sua reativação com caráter normal.Fra ca atividade sísmica parece indicar que os falhamentos não estão totalmente inativos (HABERLEHNER, 1978, e HASUI \& PON ÇANO, 1978).

Diversos autores propuseram anteriormente uma or 1 gem por falhamento ou Sistema de "Rift valley" para esse con junto de felções morfolögicas e bacias sedimentares associa das (BACKHEUSER, 1926; MAULL, 1930; WASBURNE, 1930; PAES LEE ME, 1930; MARTONNE, 1933; RUELLAN, 1944; FREITAS, 1944,1947, 1951a, b, 1956; ALMEIDA, 1953; AB'SABER \& BERNARDES, 1956, etc.

Cabe a ALMEIDA (1955) a primelra descrição detalhâ da e Identificação de falhamentos transcorrentes na região. Estudando a região da Serra da Cantarelra, ao Norte da claa de de São Paulo estabelece aI a existêncla de um sistema de falhas transcorrentes antigas, com reativação de carāter nor 
mal, a qual relaciona com a geomorfogênese da região e a ori gem da Bacia Sedimentar de são Paulo.

COUTINHO (1953) e FRANCO (1955) descrevem miloni tos e ultramilonitos na região de são Roque, SP.

Em 1965, BJÖNBERG, GANDOLFI \& PARAGUASSU, em traba Tho sobre a região Leste do Estado de são Paulo, afirmam que as falhas de rejeito horizontal prevalecem sobre as falhas normais em extensão. Assinalam a existência de um grande fa Ihamento contínuo desde Parateí de Cima atē São José dos Cam pos.

Em 1967, HENNIES, HASUI \& PENALVA descrevem o fa lhamento transcorrente de Taxaquara, estabelecendo um esque ma evolutivo, que mais tarde é generalizado para todo siste ma regional de falhamentos transcorrentes. O falhamento de Taxaquara foi descrito inicialmente numa extensão de aproxi madamente $100 \mathrm{~km}$, entre a sinēclise do Paranā e a Bacia sedí mentar de São Paulo, cortando em pequeno ângulo as estrutu ras regionais, rochas ectiniticas e corpos graniticos do Bló co de são Roque, e rochas migmatiticas e granitóides do Bló co cotia.

BRAUN (1972) afirma que o Escudo Brasileiro é re cortado por zonas de ruptura muito extensas, caracterizando-os como cinturões de rochas extremamente deformadas, com uma trama de falhas onde predominam as de caráter transcor rente de grande extensão, com largas zonas miloniticas. A estruturação geral è representada por falhas aproximadamente paralelas, ligadas entre si por falhas menores sigmoidais. A mais notável dessas zonas seria a do Rio Paraíba do sul,que condiciona o vale desse rio, prolonga-se pelo Estado de são Paulo, sendo coberta pelos sedimentos da Bacia do Paraná e reaparecendo no Rio Grande do sul.

Em 1975, ALMEIDA, HASUI \& CARNEIRO identificam e descrevem o Lineamento de Além Paraîba. Foi descrito ini cialmente num trecho de $150 \mathrm{~km}$, entre a estação Anarade Pin to e proximidades de Itaocara, Estado do Rio de Janeiro. Pog 
sul destacada expressão topográfica, sendo caracterizado por larga faixa de blastomilonitos, que atravessa diagonalmente as estruturas da "Série Paraíba" (ROSIER, 1965). Segundo os autores, o lineamento descrito corresponde a uma grande fa Tha transcorrente dextral, de rejelto desconhecido, bem ates tada pela deflexão das estruturas dos blocos adjacentes.Afi $\underline{\underline{r}}$ mam que as caracteristicas do desenvolvimento dessa falha profunda, assim como a ldade de suas sucessivas fases de at1 vidades, ainda não podem ser precısadas, mas que certamente fol ativa no Prë-Cambriano Supertor, apōs o metamorfismo do Ciclo Transamazônico, sendo suas relações com o Ciclo Brasi liano desconhectdas. Supõe por correlação com outras āreas que sua ültima fase de atividade seja brasiliana, jã duran te o Paleozóico.

Nos últimos anos, diversos pesquisadores vêm reali zando trabalhos de mapeamento geológico sistemätico na re gıão, estando a rede de falhamentos transcorrentes em boa parte mapeada, em geral em escala de semi-detalhe. Entre eles, destacam-se HASUI et al. (1969), COUTINHO (1972), HASUI (1973), SADOWSKI (1974), RIDEG (1974), ALGARTE et al. (1974), SILVA \& FERRARI (1975), BRANDALISE et al. (1976), FREITAS (1976), CARNEIRO (1977), HASUI et al. (1977a, b, 1978), COSTA et al. (1978), SILVA et al. (1978), etc.

HASUI et al. (1975) propõe a denominação de Zona de Transcorrêncta são Paulo para a região em questão, consti tulndo esta um segmento caracterizado por uma complexa rede de falhamentos transcorrentes, dividindo a Região de Dobra mentos Sudeste (ALMEIDA et al., 1976) em duas porções.

HASUI \& SADOWSKI (1976) realizaram sintese sobre a geologia e a evolução geológica do Pré-Cambriano a SE da cłdade de são Paulo, descrevendo sua compartimentação em blo cos de falhas. Consideram que os falhamentos ocorreram num nível superficlal da crosta, ocastonando fragmentação mecâni ca das rochas.

HASUI et $a$ l. (1977a, b, 1978) apresentam os resul 
tados obtidos por extenso mapeamento na escala 1:100.000 de todo o Leste paulista. Definem a rede de falhamentos trans correntes e a estruturação da área em blocos tectônicos. Con firmam a sequência de evolução estrutural desses falhamentos, assim como configurada por ALMEIDA (1955) e HENNIES et al. (1967). Sugerem que as intrusões de diabásto e rochas alca linas possuam um controle estrutural relacionado a esses fá Ihamentos. Mapelam em traços gerais a rede de falhas nor mais relacionadas às bacias sedimentares tafrogênicas e às feições geomorfológlcas. Retificam e fundamentam na estrutu. ra da rede de falihamentos a compartimentação geomorfológíca proposta por ALMEIDA (1964).

Indicam que, alēm de certamente estarem ativas du rante o Ciclo Brasiliano e reativadas no Meso-Cenozóico,exis tem "evidências de que estes falhamentos jä estivessem im plantados pelo menos no Pré-Cambriano Mëdio".

Os termos litológicos presentes vartam de protomi lonitos a ultramilonitos e até blastomilonitos. Em alguns trechos, apresentam fatias embutidas de xistos, interpretadas como encalxadas dentro das zonas de falhas pela componente vertical do rejeito.

Os maiores falhamentos são os de Taxaquara (possi velmente prolongando-se no de Alëm Paraíba, de ALMEIDA et $a l_{\text {., }}$ 1976). Cubatão (unindo-se ao de Taxaquara), Alto de Fartura (continuando no de Rio Preto, Minas Gerais), Buquira e Jun diuvira. Todos se caracterizam por uma zona de rochas cata clāsticas de mals de $1.000 \mathrm{~m}$ de espessura. Supondo verdadei ra a continuidade entre os falhamentos de Taxaquara, Cubatão e Além Paraíba, estes correspondem à mais extensa estrutura desse tipo na região.

\section{2 - Geologia da Região do Lineamento de Alēm} Paraĩba

ESCHWEGE (1932) apresentou possivelmente o primei. 
ro esboço da geologia regional da ārea, num perfil entre a Baía da Guanabara e pouco além da cidade de uberaba (Minas Gerais), alcançando o Estado de Golás. Descreve a ārea que vai do topo da Serra do Mar até pouco além do vale do rio paraíba como sendo constituỉda predominantemente de gnaís ses, com intercalações de granitos, granitos-gnaisses, dia bảsios e gabros. O vale do Rio Paraíba do sul seria cons tituldo de faixas "granitos-gnaisses" em meio aos gnaisses regionais.

BRANNER (1919) mostra a região como pertencente ao "Complexo Brasileiro", de idade arqueana. Localiza os princlpais corpos de "rochas alcalinas prē-cretáceas", as bacias sedimentares terciärias e os sedimentos quaternärios. Sobre o Estado do Rio de Janeiro afirma que "A geologia da região não tem muita variedade e geralmente as notas prin cipiam e acabam com a observação que as rochas são granitos e gnaisses".

LAMEGO (1938, 1946) afirma que o Rio Paraỉba, a partir de Barra Mansa, entra na calha de um grande sincli nal, o qual constituiria todo interior do Estado do Rio, da borda da Serra do Mar até imediações da Serra da Mantıquei ra.

LEONARDOS \& OLIVEIRA (1943) afirmam que, com ex clusão da Baixada Fluminense, todo o resto do Rio de Janeí ro pertence ao sistema orográfico da Serra do Mar, constí tuido essencialmente de gnaisses arqueanos, aqui e ali asso ciados e calcários e dolomitos sacaróides e a pequenos maci ços de granito laurentiano. De um modo geral, em toda ser ra do Mar os granttos seriam abundantes no alto da serra é iriam escasseando na direção do Rio Paraỉba. Afirmam que este corre no fundo de um vale tectônico ("strike valley"), paralelo à costa.

RUELLAN (1944), utilizando-se de métodos geomorfo lógicos fundamenta a origem por falhamento da Serra do Mar. Mostra que a Serra dos Orgãos (denominação local da serra 
do Mar) è um bloco falhado, adernado para o Norte, e o vale do Paraíba nessa região formado numa depressão de ângulo de falha.

ROSIER (1953) esboça uma cronología de eventos do Prë-Cambriano na Serra dos orgãos, na região vizinha à cida de de Teresópolis. Estabeleceu a seguinte sequência de eventos: 1) anfibolitos micáceos (para-anfibolitos na maior parte), com neossoma de material quartzo-feldspātico; complexo gnäissico, originado por granitização; 3) granitos pós-tectônicos; 4) microgranttos e pegmatitos; 5) diques de diabãsio.

ROSIER (1957) apresenta mapeamento na escala 1:250.000 de parte do interior do Estado do Rio de Janeiro (ver Anexo 1). Descreve uma estrutura regional de "nappes" de estilo alpino (denominados "nappes" da serra dos Orgãos e a do Desengano), relacionados com a orogênese assintica (brasiliana). Estes terlam sido transportados sobre o ante país que terla como cobertura o que denominou de "Falxa Pá raỉba", no vale do Rio Paraíba, de idade algonqueana. Na região de Três Rios, Indica uma sērie de "Faixas laminadas". Interpreta estas feições e a prōpria faixa Paraíba como de vidas a uma forte compressão lateral, por sua posição entre a frente do "nappe" e o antepaIs. Não admite a existência na região de "faixas miloniticas" ou de "falhas de grande rejeito".

EBERT (1957) definiu e delineou as äreas de ocor rência de várias unidades litológlcas na região sul de Mí nas Gerais e Estado do Rio de Janelro. Na região em ques tão ocorre a "Série Paraíba" (Neo-Algonqueano catazonal de granitização), e ao Norte desta, a "Sërie Juiz de Fora" (Neo-Algonqueano de charnoquitização), a "Sērie Andrelândia" (Neo-Algonqueano mesozonal) e a Formação Barbacena (Arquea no não especificado, com rochas graniticas e migmatiticas).

ROSIER (1967), no relatório anual do Diretor do D.:G.M. do ano de 1962, comenta a existência no vale do Para王 
ba no Estado do Rio de Janeiro, de um feixe de falxas de ro chas multo laminadas, com composição petrográfica de cará ter mesozona1, mais ou menos locals e descontinuas, que po dem ser incluídas numa "faixa geral laminada", com largura de atē 3 ou $4 \mathrm{~km}$, observada de Paralba do Sul atë Bom Jesus de Itabapoana. Segue inicialmente o eixo do Rio Paraíba, defletindo-se depois gradativamente para o Norte. Observa ainda que as äguas minerais de Salutaris e de Santo Antônio de pädua ocorrem sobre essa zona laminada.

$$
\text { ROSIER (1965) apresenta mapeamento na escala }
$$

1:500.000 de extensa ārea no Estado do Rio de Janelro e re giões vizinhas (ver Anexo 1). Mostra que a direção das es truturas regtonais descreve um grande arco, passando de pa ralela ao curso do Rio Paraíba do sul (ENE), atē N/S, na re gião de Caratinga. Delimita diversas unidades, sendo que a "Série Paraíba-Desengano" inclul a zona de Lineamento de Alēm Paraíba. Considera que esta fol formada durante a oro gênese assintica, sendo constituIda de charnoquitos, gnais ses diversos e migmatitos, com intercialações de mārmores, quartzitos e gnaisses granitöides. Retifica as interpreta ções anteriores, de uma tectônica de "nappes" estilo alpino, julgando-as "não totalmente passíveis de prova".

EBERT (1967) define o Grupo Paraíba incluindo as Séries Paraíba e Juiz de Fora defintdas antertormente, e mo difica os termos sērie Andrelândia e Formação Barbacena res pectivamente para Grupo Andrelândia e Grupo Barbacena.

EBERT (1968) define um novo esquema estrutural e estratigräfico para o Pré-Cambriano da região sudeste. Deli mita uma faixa orogênica assintlca subaividida em dois rá mos: os Paraibides, de direção NE-SW, e os Araxaídes, de dí reção NW, contornando o antepais. o limite entre os dois ramos seria: uma grande falha (Campinas-Pinhal-Jacutinga-Ipuiuna-são Gonçalo-Varginha).

DELHAL et al. (1969) e CORDANI et al. (1973) rea lizaram estudo geocronológico regional no sul de Minas Ge. 
rais e Rio de Janeiro, por meio de determinações U/PB,Rb/Sr e $\mathrm{K} / \mathrm{Ar}$. Retificam as idēias sobre a evolução geológica re gional de ROSIER (i965) e EBERT (1968) e Introduzem a idéła de três ciclos orogênicos sucesstvos sobrepostos na região. As Formações Barbacena (gnaisses Mantiqueira) e Juiz de Fo ra seriam arqueanas com aproximadamente $2.800 \mathrm{~m}$.a. A For mação Paraỉba do Sul seria transamazôntca (2.070 m.a.) remo bilizada durante o Brasiliano $(620 \mathrm{m.a.})$. As rochas da ser ra dos Orgãos seriam brasiltanas, com os gnaisses sintectô nicos formados a $620 \mathrm{~m} . \mathrm{a}$. , os granitos pós-tectônicos a 540 m.a. e os pegmatitos a 500-470 m.a. Reomogelnização: par clal a completa de $\mathrm{Sr}^{87}$ ocorreu sobre todas as rochas da re gião a $450 \mathrm{m.a.,} \mathrm{e} \mathrm{o} \mathrm{fechamento} \mathrm{do} \mathrm{sistema} \mathrm{K} / \mathrm{Ar}$ em hornblen. das a 470-500 m.a. Diques de diabăsio apresentaram idade de $113 \pm 6 \mathrm{~m} . \mathrm{a}$.

LIU et $a$ l. (1976) apresentam mapa geológico do Esta do do Rio de Janeiro na escala 1:500.000, baseado em intex pretação de tmagens multiespectrais MSS do satēlite LANDSAT - 1. Os critērios de interpretação basearam-se prin cipalmente na varıação das formas do relievo. Distinguem três provincias topográficas distintas: o vale do Rio Paraíba do Sul, a Serra do Mar e a Planicie Costeira. No Pré-Cambriano, distinguem três grupos: Paraíba (subdividido nas unidades $A$, $B$ e C), Serra dos orgãos (subalvidido nas unidades A, B e C) e complexo do Litoral Fluminense.

BRANDALISE et al. (1976) apresentam resultados de mapeamento 1:250.000 das Folhas Juiz de Fora (SF.23-X-D), Rio de Janeiro (SF.23-Z-B), Volta Redonda (SF.23-Z-A)e Ilha Grande (SF-23-Z-C) (ver Anexo 1). Agruparam as rochas Prē-Cambrianas em duas associações, denominadas Associação Pa raỉba do sul e Assoclação Barbacena. A Associação Paraíba do Sul fol subdividida num Complexo Charnoquitico e num com plexo Migmatitico. Afirmam ainda que uma tectônica ruptu ral compressiva no Prē-Cambriano produziu falhas de rejeito horizontal, desenvolvendo extensas faixas cataclásticas. Os maiores falhamentos descritos são os de Guiricema, Rio 
Preto, Conservatória, Barra Mansa, Ipiabas e Rio Paraíba do Sul - Médio Inferior.

SILVA \& FERRARI (1976) apresentam resultados de mapeamento na escala 1:250.000 das Folhas de Macaé (SF.24-Y-A), Campos (SF.24-V-C), Caparaó (SF.24-V-A), Vitōria (SF.24-V-B), Rio Doce (SE.24-Y-D) e São Mateus (SE.24-Y-B) (ver Anexo 1)。 As rochas Prë-Cambrianas foram agrupadas na Associação Paraj. ba do sul, subdividida nos complexos migmatiticos e charró quitico, conforme BRANDALISE et al. (1976).

FERRARI, DUPUY \& BRENNER (1977) mostram que ocor rências de rochas alcalinas da Serra dos Tomazes, municípió de Pirai, RJ, encontram-se intrudidas em metatexitos, condi cionados por zonas miloniticas. Sendo estas constituídas por blastomilonitos de granulação fina, com porfiroclastos de microclineo e faixas de quartzo estirado, tratando-se de falhamentos transcorrentes, que correspondem à continuidade do Lineamento de Alëm Paraíba para SW.

SILVA et $a \tau$. (1978) apresentam mapeamento na esca la $1: 250.000$ das Folhas Franca (SF.23-V-A), Furnas (SF.23-V-B), Divinōpolis (SF.23-X-A) e Barbacena (SF.23-X-C). Para o problema em questão, interessa a porção SE da Folha Barbace na (ver Anexo 1). AI ocorrem o Complexo Charnoquitico da Assoclação Paraíba do Sul, e a Associação Barbacena (confor me BRANDALISE et $\alpha 2 ., 1976)$, subdividida nos Complexos Pie dade (gnaisses bandados micaxistos, cataclasttos e gnaisses sieniticos), Andrelândia (micaxistos granatiferos, quartzi tos, gnaisses bandados e xistos verdes), e Complexo Migmati tico-gnäissico.

COSTA \& MARCHETO (1978) e COSTA et $a$. (1978 a,b) apresentam os resultados de mapeamento em escala 1:50.000 das Folhas Cambuci, São João do Paraiso, Italva e são Fide lis (ver Anexo 1). Os critērios de mapeamento foram estabe lecidos em seminārio promovido pelo Departamento de Recur sos Minerais do Estado do Rio de Janeiro (1978). Mostram que as rochas granuliticas sofreram um processo polifásico 
e possivelmente policíclico de deformação e metamorfismo.

$$
\begin{aligned}
& 2.3 \text { - Geologia da Folha de Três Rios (IBGE, } \\
& \text { SF. 23-Q-II-2) }
\end{aligned}
$$

As primeiras referências ä geologia da ärea são devidas a LiEONARDOS $(1935,1939)$ descrevendo ocorrência de garnierita associada a pequeno maciço peridotîtico em meio a gnaisses regionais (situada pouco a sul da ärea mapeada em detalhe neste trabalho) e ocorrência de calcário em Mou $x$ c̈ Brasil. O calcärio apresenta estrutura sacaróide, colo ração branco leitosa e composição dolomítica, com transição suave, pela aquisição de minerais silicatados, para leptini dos e biotita gnaisses regionais.

O mapa apresentado por ROSIER (1957), mostra que a ărea da Folha de Três Rios situa-se na "Faixa do Paraỉba", ocorrendo basicamente plagiocläsio-biotita-granada-sillimanita-gnaisses, localmente "conglomerāticos". Mostra a ocor rência de três faixas de gnaisses granitöides, uma ao Norte do Rio Paraíba, e duas ao Sul deste, respectivamente ao Nor te e ao sul. da localidade de Bemposta. Indica tambëm três faixas de ciartzitos, uma a Norte de Bemposta, e duas a sul desta. Na região de Chiador, indica a ocorrência de plagio cläsio-augita-hornblenda-gnaisses e plagiocläsio-microclîneo-hornblenda-biotita-gnaisses. Nas proximidades do Rio Pa raỉba do Sul, entre as localidades de Paraíba do sul e a con fluência com o Rio Paraibuna, indica a ocorrência de "fai xas laminadas", um pequeno corpo de gnaisses charnoquiticos (plagiocläsio-biotita-hiperstênio-gnaisses e microclineo-oli gocläsio-hiperstênio-gnaisses), alēm de dois diques de dia bäsios e basaltos. Ocorrem ainda na ärea dois pequenos con pos de märmore, entre Moura Brasil e Bemposta. Destacam-se - formato alongado e o paralelismo dos corpos mapeados, as sim como a atitude vertical e subvertical das estruturas.os gnaisses charnoquĩticos passam a ocorrer em āreas maiores apenas a NW do Rio Preto, fora da Folha de Três Rios. 
Os dados radiomëtricos levantados por DELHAL et al. (1969) e CORDANI et al. (1973) concentram-se em grande parte da ārea da Folha de Três Rios, sendo discutidos mais adiante (item 3.8 ).

Em 1978, o Departamento de Geologia da UFRJ, em estágio de campo do Curso de Graduação, realizou perfil geo lögico na escala $1: 20.000$ da Rodovia BR-040, entre Bingem (Petropölis) até a divisa com o Estado de Minas Gerais. o trabalho de graduação de VASCONCELOS \& MIRANDA (1978) abran ge trecho desse perfil praticamente coincidente com a ärea de detalhe do presente trabalho. Mostram a ocorrência de uma faixa de cerca de $10 \mathrm{~km}$ de milonito-gnaisses e milont tos, correspondentes ao Lineamento de Além Paraíba, ladeada por migmatitos estromatíticos. Descrevem vãrias litologias de ocorrência menor, como calcossilicatadas, charnoquitos e quartzitos, assim como as estruturas observadas. 
3 - AREA DE TRES RIOS

\section{1 - Localização da Area Escolhida e Trabalhos Realizados}

Após a seleção e anālise de mapas topográficos, imagens de satélite e bibliografia referentes à região na qual o Lineamento de Alëm Paraíba foi originalmente descri to partiu-se para uma fase de reconhecimento preliminar no campo, na extensão do Lineamento desde a Via Dutra (BR-116), pouco a Sul de Volta Redonda, até pouco a nordeste de Alēm Paraíba. Realizou-se caminhamentos geológicos transversais à Zona de Rochas Blastomiloniticas nas localidades de Alëm Paraíba, Três Rios, Paraíba do Sul e Andrade Pinto. A ărea de Três Rios mostrou-se ser a que oferecia melhores con dições em termos de acesso e afloramentos existentes, além de oferecer problemas geológicos interessantes. E cortada por rodovias importantes, como a BR-339 (Volta Redonda-Itaperuna) a BR-116 (Rio-Bahia) e a BR-040 (Rio-Belo Horizonte). Por ocasião dos trabalhos de campo executava-se no trecho Petró polis-Três Rios da BR-040 trabalhos de duplicação e retifí cação do trajeto, dispondo-se de afloramentos de rochas fres cas quase que continuos ao longo de um perfil perpendicular à direção das estruturas. 'A ārea também é cortada por vâa rios troncos e ramais ferroviários, oferecendo bons aflora mentos. Para fornecimento de brita para as ferrovias e ró dovias, foram abertas diversas pedreiras, além de lavras de dolomito para uso na indústria siderürgica e como corretivo de solos,e de quartzitos (alterados) para uso no leito das estradas em construção. Afora isso, a ārea è cortada por três grandes rios, 0 Paraíba do Sul, o Paralbuna e O Piabanha, os quais, durante a época da vazante, oferecem ótimos aflora mentos de rochas frescas em seus leitos,por vezes com cente nas de metros de extensão. Uma boa malha de estradas subsidiä rias e de acesso a sitios e fazendas garante a penetraçãono restante da ărea. Trata-se também de uma ărea que possui le vantamentos geológicos de semi-detalhe (ROSIER, 1957, 1965; 
BRANDALISE et al., 1976) e estudos geocronológicos relativa mente detalhados (DELHAL et al., 1969; CORDANI et al.,1973). Todos estes fatores fizeram com que fosse escolhida para ma peamento de detalhe.

Como base topográfica, adotou-se a Folha de Três Rios, escala 1:50.000 (IBGE; SF.23-QII-2, 1966). Utilizouse tambëm os levantamentos aerofotogramétricos da SACS-PROSPEC (escala 1:36.000) e USAF (escala 1:60.000).

Em função dos objetivos propostos, não se julgou necessāria a apresentação de mapa geológico abrangendo toda Folha de Três Rios, mas apenas uma ārea mỉnima que contives se a faixa de rochas intensamente deformadas e porções ime diatamente contíguas dos blocos adjacentes. A localização dessa ārea escolhida encontra se ilustrada na Figura 1 (mapa de localização) e Anexo 2 (mapa de pontos de afloramentos). Totaliza $550 \mathrm{~km}^{2}$.

Segundo a metodologia de trabalho esboçada no Capi tulo 1, foram descritos no total (Incluindo toda Folha de Três Rios e porção adjacente da Folha de Paraíba do Sul) 256 pontos (que podem realmente corresponder a afloramentos "pon tuais" no mapa, ou simplesmente servir de referência à loca 1ização de afloramentos ou perfis maiores, continuos por até centenas de metros). Foram coletadas 223 amostras, prepara das e analisadas 165 seções delgadas e uma seção polida. Den tro da ārea do esboço geológico apresentadn (Anexo 31 foram descritos 183 pontos. Algumas āreas receberam maior atençäo e detalhe, como aquela em torno do Rio Paraíba do Sul, desde pouco a montante da cidade de Três Rios até sua confluência com os Rios paraibuna e Piabanha. A distribuição dos pontos de descrição, amostras coletadas e seções delgadas prepara das, encontra-se indicada no Anexo 2.

\section{2 - Estruturação Geolögica}

Na área mapeada pode-se caracterizar três unidades 


\section{MAPA DE LOCALIZAÇÃO}

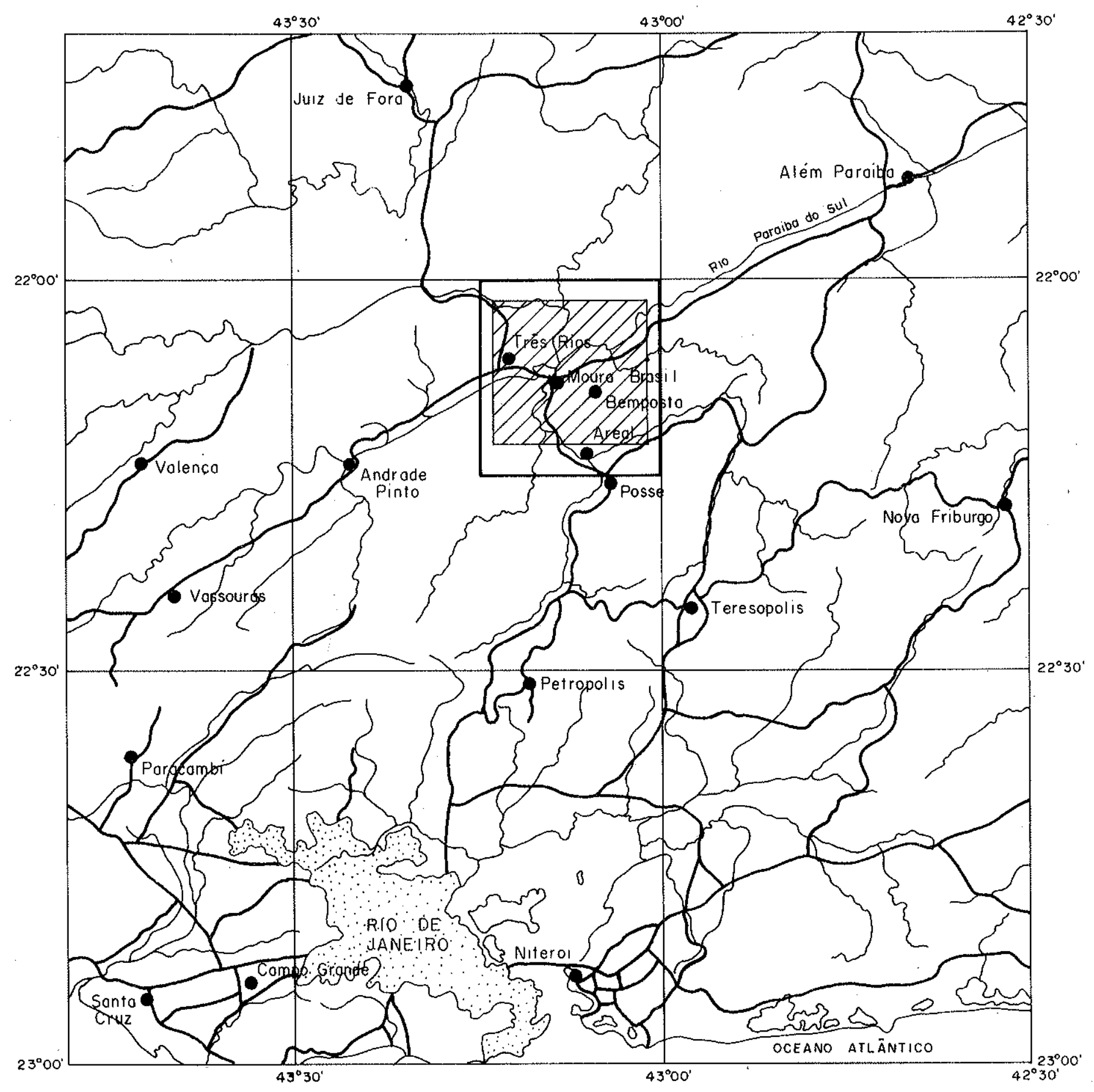

\section{LEGENDA}

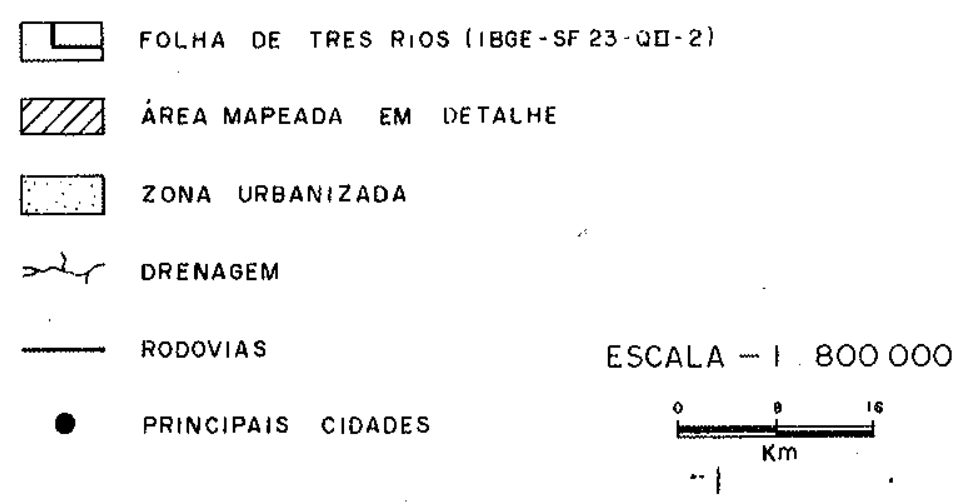

Campanho, 1980

Desenho: Wilson R. Leōo

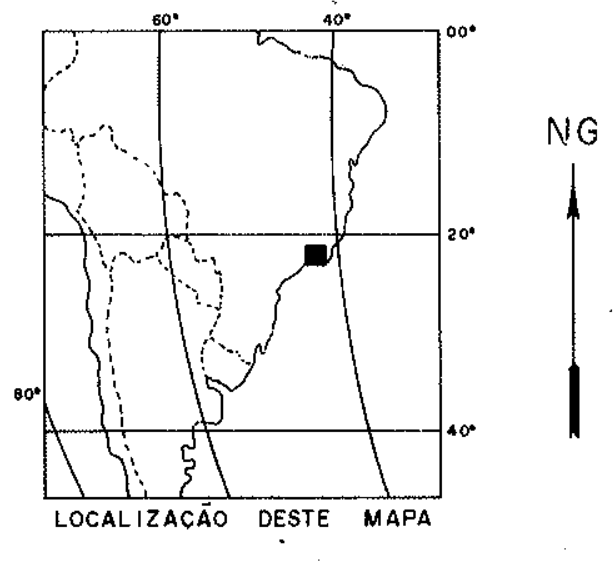

FIGURA I 
liţológico-estruturais distintas: A Zona de Rochas Blastomi loniticas, o Bloco NW e o Bloco SE, estes dois ūltimos adja centes à Zona de Rochas Blastomiloniticas e preservados da cataclase e deformações intensas. A zona das Rochas Blasto miloniticas por sua vez, pode ser subdividida em zona Prin cipal de Deformação e zonas de transição, a NW e a SE, sepa rando a Zona Principal de Deformação dos blocos adjacentes. Esta estruturação encontra-se ilustrada na Figura 2, estando representadas tambëm as faixas nas quais se supõs que ocor reram os ültimos movimentos transcorrentes, conforme é discu tido mais adiante.

Por Zona Principal de Deformação entende-se aqui uma faixa com cerca de $3 \mathrm{~km}$ de largura, constituida prepon derantemente por rochas com feições cataclästicas muito cons pỉcuas, tanto macro como microscopicamente, porëm fortemente recristalizadas. Apresentam uma intensa foliação vertical a subvertical, extremamente conspícua e laminar, com dobras in trafoliais, cerradas e fortemente transpostas, assim como in tenso padrão de lineações subhorizontais. Constitui-se na escala 1:50.000, de faixas paralelas com predominância de blastomilonitos ou milonito-gnaisses. As zonas de transição correspondem a faixas imediatamente contíguas à zona Princi pal de Deformação. Nestas as estruturas cataclästicas, a fo liação vertical a subvertical, o padrão de dobramento e transposição da Zona Principal de Deformação, assim como as lineações subhorizontais, impõe-se sobre as estruturas meta mórficas anteriores, sem destruí-las totalmente e preservando frequentemente blocos de rochas pouco afetadas pela defor mação. Estes são observāveis em todas as escalas, e às vê zes mapeáveis na escala 1:50.000. As rochas predominantes são milonito-gnaisses.

A Zona de Transição NW possui aproximadamente 1,5 $\mathrm{km}$ de largura, com uma faixa de migmatitos estromatiticos in tercalada nos milonitós-gnaisses. A zona de Transição SE possui cerca de $4,5 \mathrm{~km}$ de largura, apresentando estruturação 
mais complexa, com intercalações de corpos alongados de ro chas preservadas da deformação intensa, incluindo migmati tos, rochas carbonāticas e granulitos. A zona de Rochas Blastomiloniticas possui no total uma largura de aproximada mente $9 \mathrm{~km}$.

Os blocos adjacentes constituem-se de rochas meta mörficas de médio e alto grau não afetadas pela deformação intensa, a não ser localmente. O bloco a NW da Zona de Ro chas Blastomiloníticas constituí-se, dentro da área mapeada, de gnaisses bandados com migmatização incipiente, que pas sam gradualmente no canto $\mathrm{NW}$ da área mapeada para rochas de aspecto granitóide. O Bloco SE constituí-se de uma faixa de quartzitos e migmatitos estromatíticos indiferenciados na escala de mapeamento, seguida de uma faixa central de migma titos com estrutura nebulitica predominante, passando para migmatitos estromatíticos no canto $\mathrm{SE}$ da ārea mapeada.

o contato entre algumas unidades na zona de Rochas Blastomiloniticas por vezes è relativamente brusco e retili neo. Eventualmente foram encontradas nesses contatos faí xas métricas de blastomilonitos muito finos e foliados. Uma das interpretações possíveis para estas feições é de que correspondem a faixas nas quais concentraram-se os movimen tos transcorrentes tardios, como está representado na Figu ra 2, seccionando a Zona de Rochas Blastomiloniticas. Fá lhas transcorrentes menores foram observadas com atitudes em torno de $\mathrm{N} / \mathrm{S}$, com rejeitos em geral não representāveis na escala adotada.

\section{3 - Condicionantes Geológicos da Fisiografia}

A morfologia e o padrão de drenagem encontram-se fortemente relacionados com a estruturação geológica da ārea.

Os três principais rios que cortam a ārea, o Paraí ba do Sul, o Paraibuna e o Piabanha, tem seus cursos forte mente condicionados pelas direções estruturais. o primeiró 


\section{ESTRUTURAÇĀO GEOLÓGICA \\ ÁREA DE TRÊS RIOS}

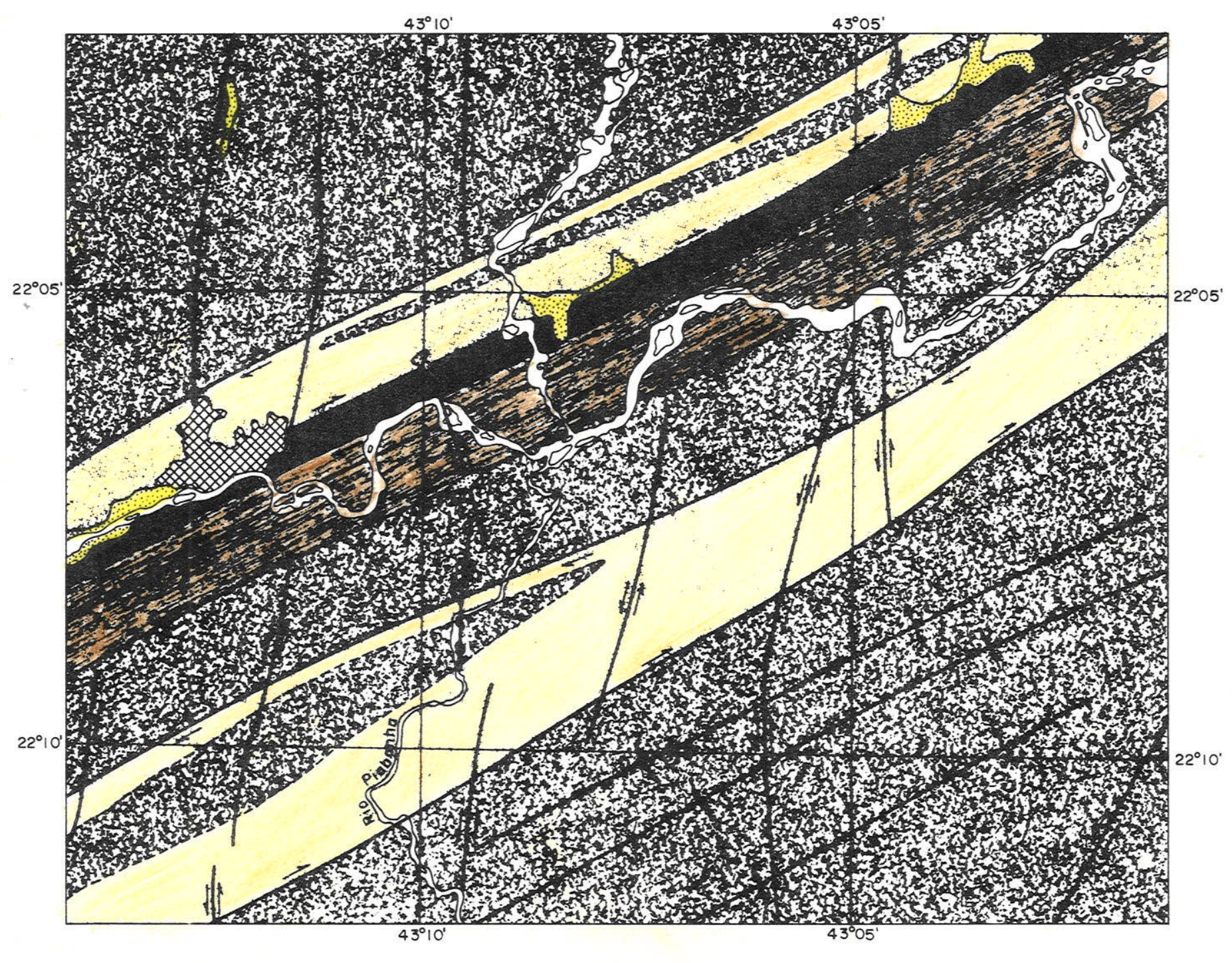

LEGENDA

Aluvioēs

Zona Principal de Deformaçāo

Zonas de tronsiçāo

Blocos adjocentes nōo deformados e Glocos de rochos preservodos dentro

Xntiformo

$X$ sinformo

Rea principais cursos d'água

Zono urbanizado

Foixas nos quais supostamente concentraram

Companho, 1980

$\begin{array}{llll}2 \mathrm{~km} \quad & 0 \mathrm{Km} & 4 \mathrm{~km} & 6 \mathrm{Km}\end{array}$


a grosso modo, atravessa a ärea paralelamente à foliação, e os outros dois perpendicularmente. O Rio Paraỉba do sul pe netra na área mapeada na cota de $275 \mathrm{~m}$ em relação ao nível do mar, saindo desta na cota de $235 \mathrm{~m}$. Seus cursos apresen tam padrão retangular, encaixados em estruturas paralelas à foliação (N7OE) e em fraturas obluquas a esta (N30W e N/S).A drenagem mais fina, dentro da zona de Rochas Blastomiloniti cas, tem um padrão em treliça quase que perfeito. Nos" blo cos adjacentes, a drenagem mais fina tende para um padrão mais dentritico, embora os cursos d'ägua principais frequen temente tendam a seguir a direção da foliação, ou são às ve zes perfeitamente retilineos, encaixados em lineamentos de direção N/S. A direção de fraturamento N30W tambēm mostra por vezes forte influência.

A morfologia da área apresenta-se também fortemen te condicionada pelas estruturas e litologias locais, cuja influência se sobrepõe ao padrão regional, que corresponde a uma superficie de aplainamento, soerguida e basculada por fa lhamentos normais (bloco da serra dos örgãos, ver RUELLAN, 1944)。

A Zona de Rochas Blastomiloniticas corresponde a uma faixa deprimida, com relação aos blocos adjacentes, com uma porção central mais elevada (ver perfis, Anexo 6).

O Bloco NW não possui um destaque muito grande em relação à Zona de Rochas Blastomiloníticas, como se vê nos perfis, apresentando uma elevação das cumeadas gradativa e suave para $N W$ atingindo dentro da área a cota māxima de $555 \mathrm{~m}$ em relação ao nivel do mar.

Já o Bloco SE apresenta-se como uma superfície dis secada com cota máxima de $878 \mathrm{~m}$. Esta termina aproximadameñ te junto ao limite com a Zona de Transição $S E$, a qual se mos tra arrasada. Para o sul, as cotas das cumeadas elevam-se gradativamente, atingindo $1.200 \mathrm{~m}$ no limite Sul da Folha de Três Rios. Dentro da ārea, as elevações principais recebem os. nomes de Serra do Monte Alegre, Mundo Novo, dos Portões, 
da Cotia, do Tubarão e Mãe Joana.

Na região central da Zona de Rochas Blastomiloniticas configura-se uma morfologia de serrotes retilineos, e paralelos entre si, com as respectivas cumeadas a diferentes alturas, bem distintas, configurando um relevo "escalonado (ver Foto 1 e perfis, Anexo 3). Estas elevações apresentam-se em mapa como faixas, de largura regular (com faixas des de 0,3 atē $1,1 \mathrm{~km}$ de largura), extensas por vārios quilôme tros, e separadas por depressões pouco profundas, estreitas e extremamente lineares tambēm com quilômetros de extensão. $\mathrm{Na}$ altura da cidade de Três Rios estas feições recebem a de nominação local de serra Boa Vista. A faixa mais elevada, corresponde a crista da serra Boa Vista, com cota máxima de $679 \mathrm{~m}$. A faixa mais rebaixada possui o ponto mais elevado na cota de $341 \mathrm{~m}$.

Os milonito-gnaisses "b", das zonas de transição, correspondem em geral às āreas mais arrasadas, com cotas nos pontos mais baixos que podem chegar a 280-300 m. No entanto, dentro das āreas mapeadas com essa litologia, são freqüentes tambēm os pontos mais altos, atingindo um mäximo de $656 \mathrm{~m}$ 1o go a NW da ārea mapeada. Alëm disso, as intercalações maió res, mapeáveis, de rochas preservadas da deformação intensa (migmatitos em geral), dentro das zonas de transição, corres pondem normalmente a elevações alongadas, de contornos suá vemente curvilineos. São exemplos destas ültimas feições as Serras do Mato Alegre e da Carioca. Podem atingir cotas de $520 \mathrm{~m}$ (Serra do Mato Alegre) e $542 \mathrm{~m}$ (Serra da Carioca).

\section{4 - Litologias}

A descrição das diversas litologias é feita de acordo com os critérios e nomenclatura expostos no capítulo 1 . 


\subsection{1 - Rochas Blastomiloníticas}

Mesoscopicamente, são rochas fortemente foliadas e bandadas, com bandamento regular e laminar, observāvel por dezenas a centenas de metros (ver Fotos $2,3,5$ e 6).

Apresentam uma textura dual tipica. Observa-se uma fração de porfiroclastos, com felções de deformação conspi cuas. E uma fração em geral mals fına, em forma de matriz granoblästica a granolepidoblástica recristalızada ou neofor mada segundo as condições refletidas por sua paragênese, señ do em geral isenta de deformação (Fotos 7 a 10).

Os pofiroclastos representam relíquias de uma asso ciação mineralōgica antertor de fácies granulito,observando-se porfiroclastos de plagioclāsto (oligoclästo), microcíneo, mesopertita, pertita, antipertita, quartzo, granada, diopsi dio, hornblenda, hiperstênio, sillimanita, opacos. Em geral, encontram-se duas associações distintas, uma com predominân cla de piroxênios e anfibólios, e outra com predominância dé feldspatos.

Microgranulação nas bordas dos grãos deformados ë uma feição comum a todos os porfiroclastos. Quando se trá tam de granadas, piroxênios e minerais opacos, esses cris tais menores microgranulados são claramente cataclásticos,mas em outros minerais mostram-se em geral isentos de deformação. Quase todos os porfiroclastos mostram formas arredondadas ou elipsoidais, neste ültim caso sempre com o eixo maior parale 10 à foliação da rocha (Fotos 35 a 40).

Extinção ondulante é regra em porfiroclastos de feldspatos, anfibólios, piroxênios, sillimanita e quartzo. o plagioclásio mostra geminações polissintēticas encurvadas, mas não falhadas ou fraturadas. O quartzo como porfiroclas tos ë raro, ocorrendo em geral recristalizado na forma dé quartzo planar. Granada apresenta-se em geral fraturada, com formas arredondadas e minerais recristalizados nos intersti cios abertos pelas fraturas; não foram encontradas evidên 
clas nItidas de rotação. Diopsidio e hiperstênto, encontram-se normalmente fraturados, com frequência parclalmente trans formados em hornblenda, recristalizada, sem deformações. Me sopertitas e pertitas encontram-se com frequência parcial ou quase totalmente transformadas em microclineo. Essa micro clinização aparenta começar nas regiões mais deformadas do grão. A sillimanita,quando ocorre como porfiroclastos,apre senta certas bordas serrilhadas, extinção ondulante fracamas observāvel e formato irregular, podendo-se em alguns casos observar-se vestígios da forma original.

A matriz apresenta-se com texturas de granoblástí ca a granolepidoblástica, com assoclaçōes mineralögicas de fácies anfibolito, contendo plagioclásio (oligoclásio), bio tita, quartzo, microclíneo, sillimanita, hornblenda, apatita, opacos. Essa matriz encontra-se frequentemente poligonizada, com texturas de equilíbrio plenamente desenvolvidas, formando um mosalco de grãos com aparência hexagonal, com pontos trí plices de contatos em ânigulos aproximadamente iguais (Fotos 7 a 10). Em algumas lâminas a matriz constituí-se predominan temente de microclíneo. A textura granolepidoblástica è da da pela orientação das biotitas, quando estão presentes, sen do que os demais minerais apresentam-se num agregado granu lar, poligonizado. Tanto os minerais da matriz como o quart zo em forma planar em geral não apresentam extinção ondulan te. Ou apresentam multo fracamente, a não ser localmente, quando também podem ocorrer outras evidências de deformação. Eventualmente, outros minerais de tamanho equivalente aos da matriz são encontrados (piroxênio, granadas), mas em geral apresentam caracteristicas cataclästicas. Muscovita e clori ta são localmente encontradas mostrando em geral evidênclas de serem produtos de alteração de blotita; feldspatos, anfi bölios e piroxênios. Muito raramente, as biotitas são encontradas com lamelas deformadas.

As rochas blastomiloniticas possuem como caracte ristica, textural microscópica mals proeminente uma forte fo 
liação dada por placas de quartzo planar ("flatten-quartz", "ribbon-quartz", quartzo discöide) e pela orientação de lame las de biotita, alēm da orientação dos porfiroclastos. quartzo planar forma placas constituidas de värios grãos de quartzo em geral 1sentos de qualquer felção de deformação,com contatos entre si ameböides, apresentando orientações crista logräficas ligeiramente diferentes, evidenciadas pelas diferentes posições de extinção dos grãos (Fotos 9, 17, 35 e 37). Observam-se às vezes pequenas inclusões dispostas em arranjos retilíneos dentro do grão de quartzo, demarcando provavelmen te o antigo agregado cristalino deformado, antes de sofrer re cristalização.

Sombras de pressão freqtentemente desenvolvem-se em torno dos porfiroclastos, principalmente nas suas extremi dades, encontrando-se aI as mesmas associações mineralögicas da matriz, com bordas de equilibrio bem desenvolvidas e fre qüentemente envolvidas por cordões de quartzo planar, que con tornam o porfiroclasto e as sombras de pressão (Fotos 7 e 8). Tambēm a microgranulação de feldspatos e quartzo desenvolve texturas de equilibrio nas bordas dos cristais configurando texturas "em moldura". Eventualmente todo o porfiroclasto é transformado numa massa de cristais menores com textura po ligonizada, podendo-se em alguns casos se notar a forma ori ginal do porfiroclasto.

Perpendicularmente à follação da rocha observa-se, mesmo em lâmina, variações pronunciadas na textura e composi Ção mineralögica (Fotos 38 e 40), fornecendo na escala mesos cópica o bandamento pronunciado a laminar dessas rochas. Ocor rem no sentido lateral pronunciadas variações composicionais na matriz, com bandas bem definidas, com contatos graduais ou bruscos na escala microscópica, constttuldas por variação na quantidade de biotitas. Também nos porfiroclastos, ocorrem bandas mais māficas (com piroxêntos e anfibōlios) e bandas mais félsicas (com feldspatos dominantes). Ocorrem ainda va riações na quantidade de granadas nas vārias bandas. Notam-se 
tambëm bandas e porções mais ou menos microclinizadas, porēm tal variação ē mais difusa. Em alguns blastomilonitos finos, a matriz é quase que totalmente constituía de microclíneo, dando uma cor fortemente avermelhada à rocha, de aparência afanitica. Texturalmente apresentam-se variações laterais na quantidade e tamanho dos porfiroclastos. Em lâmina è comum observar-se em matriz mais fina dominante, longos alinhamen tos de porfiroclastos, em geral de um só tipo de mineral (hi perstênio, diopsídio, sillimanita, opacos, etc.).

No caso da sillimanita, é possível observar-se um cristal maior deformado, seguido de uma longa esteira de cristais menores recristalizados.

As rochas blastomiloniticas foram diferenciadas no campo e em lâmina, em milonito-gnaisses e blastomilonitos.Ca da um desses tipos por sua vez foi subdividido em outros dois, de acordo com suas características de deformação. Fo ram ainda descritas rochas com deformação inciplente, inter mediārias entre as rochas blastomiloníticas e as não defor madas.

Blastomilonitos tipo "b" (pebb) - Ocorrem tipica mente na Pedreira Moura Brasil (Tabaiara). Possuem a apa rência de gnaisses finamente cristalinos, foliados e lamina dos com raros porfiroclastos visiveis a olho nu. Em seção delgada, mostram que o bandamento pronunciado que apresentam; constitui-se de bandas alternadas, mais ou menos ricas em biotitas. Em seção delgada a matriz recristalizada, poligo nizada, com cordões de quartzo planar, predomina francamente sobre a porção de porfiroclastos (Fotos 3, 6 e 17).

Blastomilonitos tipo "a" (Peba) - Ocorrem tipica mente na margem direita do Rio paraíba do sul, em cortes da estrada que contorna a cidade de Três Rios pelo lado Oeste. Tambëm na margem esquerda do paraíba do sul, no leito retifi cado da BR-040 (Rio-Belo Horizonte), $200 \mathrm{~m}$ depois de cruzar - rio, e em cortes da estrada de ferro e estrada de rodagem, nạ altura em que cruzam o Rio Paraibuna, próximo a Três Rios. 
Mostram aparência muito fina, afanitica, muito semelhante a quartzitos finos ou a "chert". Apresentam-se às vezes cons picuamente bandados, e outras vezes totalmente homogêneos. Em lâmina mostram granulação muito fina. Às vezes possuem lamelas de biotita deformadas em meio a matriz, sendo estas preservadas da deformação em sombras de pressão de porfiro clástos. Mostram às vezes feições como cordões de quartzo. planar dobrados e/ou fraturados, com extinção ondulante, e planos de crenulação cortando obliquamente a foliação ante rior. Observa-se eventualmente a microclinização da matriz e tambëm às vezes grandes porfiroclastos isolados de micro clíneo, com dimensões que podem exceder $5 \mathrm{~cm}$ (Fotos 18 e 20). Milonito-gnaisses tipo "a" (Pebga) - Apresentam estrutura "flaser" típica, com porfiroclastos maiores (atë centimētricos) em grande quantidade, em geral de feldspatos, alinhados e em forma de "olhos" ovalados. Possuem forte fo liação e texturas cataclāsticas conspícuas com bandamento e acentuada variação de texturas no sentido perpendicular à foliação. Ocorrem tipicamente no leito e margens do Rio Pa raíba do Sul, sob a ponte do trajeto retificado da $\mathrm{BR}-04 \overline{0}$ (Rio-Belo Horizonte) (Fotos 2, 16, 24 e 25).

Milonito-gnaisses tipo "b" (pebgb) - Ocorrem tipi camente nas zonas de transição. Apresentam caracteristicás de deformação menos claras, e mega-crịtais menores e menos abundantes que o tipo "a". Mesoscopicamente, possuem estrú tura de gnaisses oftalmiticos. Em lâmina normalmente é pos sível estabelecer seu carāter cataclästico. Porēm em alguns casos, mesmo assim tal tarefa é dificll, observando-se um conjunto de cristais maiores xenomorfos, em meio à matriz fina, porém sem que os primeiros denotem caracteristicas de deformação extremamente nítidas (Foto 15).

Rochas com deformação incipiente - Tanto na zo na de Rochas Blastomiloniticas como fora dela, é comum observar-se rochas que, em seção delgada, possuem caracte rísticas de cataclase incipiente. Em geral apresentam tex. 
tura granoblāstica ou granolepidoblāstica grosseira,

com cristais maiores com extinção ondulante e geminações encurva das, com texturas em moldura nas suas bordas, sendo os in tersticios estreitos entre os maiores cristals deformados, preenchidos por agregados finos recristalizados (Foto 14). Em bora sejam relativamente frequentes, não formam corpos mapeā veis na escala adotada.

$3.4 .2-$ Migmatitos

Nebulitos - Ocorrem numa falxa maior dentro do Blo co SE, podendo tambëm ser encontrados em corpos de formato alongado preservados dentro da zona de Transição SE e no can to NW da área mapeada.

Em amostras manuais ou em pequenos afloramentos, es tas rochas poderlam ser descritas como granitóides, gnaisses grosseiros e homogêneos, mlgmatitos ou gnaisses com estrutu ra oftalmítica. Nas melhores exposições no entanto, obser va-se que a estrutura nebulitica predomina, porëm localmente com associações complexas de migmatitos de estruturas oftal mítica, estromatitica e agmatitica. Os contatos entre os vâa rios tipos são normalmente difusos e gradacịonais.

Microscopicamente, estas rochas apresentam textu ras granoblāsticas e granolepidoblásticas, com granulação vạ riável (Foto 13). Quando bandadas, apresentam bandas mais biotíticas, granolepidoblásticas, e bandas mais grosseiras, granoblāsticas. As associações mineralógicas małs comuns são de plagioclásio, quartzo e biotita, sendo comuns o micro clíneo e alteração de biotita em muscovita, podendo também ser encontrados granada, sillimanita, zircão e apatita.

Oftalmitos - A estrutura oftalmítica é normalmente encontrada associada com outros tipos de estruturas migmatí ticas, sendo localmente predominante. Eventualmente torna-se dificil a distinção entre oftalmitos verdadelros e milo nito-gnaisses tıpo "b", com texturas cataclāsticas pouco ní. 
tidas. Não foram encontrados corpos com predominância de oftalmitos, representäveis nesta escala de mapeamento.

Estromatitos - migmatitos com estruturas estromatí ticas foram mapeadas em um corpo alongado na zona de Transi Ção NW, no canto SE da área, e em associação com quartzitos no Bloco SE e no Bloco NW. Fora isso, encontram-se frequen temente associados a outros tipos de migmatitos. Nos corpos citados possuem em geral paleossoma gnäissico, de textura granolepidoblästica, com microclíneo, biotita, plagioclásio, quartzo, opacos, apatita. o neossoma é quartzo-feldspātico, com textura granítica. Muito raramente apresentam paleosso ma xistoso, configurando tipos mais heterogêneos. Melanos soma e leucossoma são às vezes observados, sendo o primeiro representado por faixas estreitas preponderantemente biotiti cas orlando os paleossomas.

Agmatitos - Foram observados localmente, em corpos não mapeāveis na escala adotada. São encontrados associados aos granitóides e nebulitos do $\mathrm{Bloco} \mathrm{SE}$, e tambëm a rochas da Zona Principal de Deformação, neste ūltimo caso com pá leossoma granulitico e/ou blastomilonitico.

\section{4 .3 - Gnaisses Bandados}

Ocorrem tipicamente no Bloco NW, numa faixa larga em contato com as rochas blastomiloniticas, ou ainda associa dos a milonito-gnaisses e migmatitos das zonas de transição.

Normalmente apresentam alguma migmatização. Porēm, como em regra o neossoma perfaz menos que $20 \%$ do volume da rocha, não foram denominadas de "migmatitos".

No Bloco NW possuem bandas gnáissicas, com textú ras granolepidoblāsticas, félsicas (com microclíneo em quan tidade variāvel, biotita, plagioclásio, quartzo, apatita,opá cos, e às vezes hornblenda), bandas de composição anfibolí tica (hornblenda, plagioclásio, carbonato, zircão, apatita)é 
raramente granuliticas (diopsidio, granada, quartzo, plagio clásio, carbonato, zircão, apatita).

Ocorrem tambêm em faixa constituída de assoclação indiferenclada de milonito-gnalsses e migmatitos estromatí ticos, na Zona de Transição SE. Observam-se bandas gnãissi cas, granolepidoblásticas (com granada, biotita, quartzo,mus covita, sillimanita, plagłoclásıo, opacos), com quantidade variável de biotitas, bandas calcossilicatadas, raras (com microclíneo, diopsidio, biotita, plagioclásio, escapolita, car bonato, anfibölio, opacos), e bandas mäflcas (com diopsídio, escapolita, quartzo, biot1ta).

\section{4 .4 - Quartzitos}

Ocorrem principalmente associados com migmatitos estromatiticos no Bloco $\mathrm{SE}$ e no canto $\mathrm{NW}$ da área mapeada. Em menor proporção ocorrem associados com nebulttos e granitói des do Bloco SE, e milonito-gnaisses da Zona de Transição SE, a NE de Bemposta. Embora possam ser relativamente espessos, são dificeis de serem mapeados, pols frequlentemente são des contínuos, e apresentam transições graduais e difusas para os migmatitos através do aumento relativo da quantidade de feldspatos e micas. E possivel também que estruturas de re dobramento compliquem a forma desses corpos. Por estes moti vos, não foram representados em mapa como corpos isoliados, mas sim em associações 'litológicas. Alēm do quartzo, são en contrados comumente biotita, muscovita, stlilimanita e micro clíneo. Apresentam em geral texturas granulares e granobläs ticas, eventualmente com orientação das lamelas de biotita. Mostram por vezes bandamento, com bandas mais quartzosas e bandas mais impuras.

\section{4 .5 - Rochas Granuliticas}

Paragênẹses de fácles granulito estão representa 
das pelas assaciações mineralögicas dos porflroclastos de ro chas blastomiloníticas (hiperstênio, diopsidio, granada, me sopertita, pertita, plagioclásio, quartzo, hornblenda, etc.), por enclaves tectônicos e "boudins" de rochas granulíticas não deformadas dentro da Zona de Rochas Blastomiloniticas,não mapeäveis na escala adotada, e por bandas centimētricas ra ras nos gnaisses bandados no Bloco NW. Porém neste último caso, sem paragêneses comprovadamente diagnösticas (ver item 3.4.3). As principais ocorrências estão assinaladas no mapa geológico. Trata-se em geral de granulitos básicos, com tex turas granoblāstica e granolepidoblāstica, quase sempre com alguma evidência de cataclase, de granulação variável, com associações de hornblenda, diopsídio, hiperstênio, plagioclā sio, quartzo, apatita e opacos; e também de magnetita, quart zo, hiperstênto e plagioclásio (Foto 11). Encontram-se even tualmente migmatizados.

\section{4 .6 - Rochas Carbonäticas e Calcossilicatadas}

São encontradas princtpalmente na zona de Transí ção SE, em dois corpos com largura decamētrica e esparsadä mente em outras unidades em bandas centimëtricas a mëtricas, e na forma de "boudins". As principais ocorrências estão as sinaladas no mapa geológico. Variam desde mârmores dolomí ticos bastantes puros, recristalizados e grosselros até ro chas calcossilicatadas, impuras, foliadas e de granulação fi na. Mostram bandamento composicional difuso. Cristais maió res mostraram granulações de borda e outras evidências de de formação, como estrias e lineações, mas são sempre fortemente recristalizadas.

As rochas carbonāticas impuras mostram associações de: a) carbonato, diopsidio, olivina, clorita; b) carbonato, escapolita, granada, diopsídio, quartzo, plagioclásio e c) microclíneo, diopsidio, biotita, plagiocläsio, escapolita, opacos, anfibólio. Parecem ocorrer como mineral carbonätico tanto calcita como dolomita. 
$3.4 .7-$ Anfibolitos

A ocorrência de rochas de composição anfibolítica é comum na forma de bandas em gnaisses e rochas blastomilo nitticas, e em paleossomas de migmatitos. Tambēm aparecem comumente na forma de "boudins". Dentro da zona Principal de Deformação apresentam comumente texturas blastomilonîti cas (Foto 12). Quando pouco afetados pela deformação podem apresentar texturas nematoblästicas e granoblástica. Apre sentam-se tanto associações com hornblenda, biotita, quart zo, plagioclásio, apatita, opacos, como associações conten do quantidades menores de diopsídio e hiperstênio, em parté transformando-se em hornblenda (granulitos anfibolitizados).

\subsection{8 - Rochas Intrusivas}

São relativamente comuns dentro da Zona Principal de Deformação, diques de diabäsio, que penetram por fratú ras, cortando todas as estruturas anteriores. Uma amostra da qual foi feita seção delgada, mostra textura subofítica. com plagioclásio, clinopiroxênio, opacos, olivina e hornblen da (rara).

Foram encontrados tambëm dois pequenos diques de lamprófiros, com espessuras centimëtricas e extensões obser văveis em afloramento de metros a dezenas de metros (Fotó 49). Um corta blastomilonitos da Zona Principal de Deforma Ção (Pedreira Moura Brasil) e outro, migmatitos do Bloco SE. próximo à parede do dique apresentam fenocristais de bioti ta orientados, e na parte central caoticamente distribuidos. A matriz mais fina mostra textura ladrilhada com feldspato potássico, clinopiroxênio, apatita, quartzo (cerca de 10\%) e titanita. Possuem composição pröxima a de "minettes", po rëm com teor relativamente alto de quartzo. Podem portanto ser denominados de "quartzo-minettes".

são encontrados tambëm corpos de pegmatitos, em 
forma de bolsões irregulares nas rochas blastomilonIticas,pe netrando por planos de falhas com direções em torno de $\mathrm{N} / \mathrm{S}$ e em diques tabulares que cortam obliquamente as rochas blas tomiloníticas. Neste último caso, não apresentam nenhụma felção de deformação, possuindo paredes planares e engloban do xenólitos de rochas blastomiloniticas (Fotos 21 e 22). Nos outros casos, apresentam em geral texturas bastante grossei ras, com massas localizadas de grandes cristais de quartzo e microclineo, alëm de cristais dispersos de fluorita. Apresen tam no entanto alguma deformação, com cristais malores de quartzo e microclíneo com extinção ondulante, quartzo planar com fraca extinção ondulante, e matriz de granulação média, com texturas de equilíbrio bem desenvolvidas e fraca extin ção ondulante, composta de plagioclásio, microclíneo, musco vita, quartzo e opacos.

Fol encontrado próxtmo ao plano de uma falha de dí reção $\mathrm{N} / \mathrm{S}$ um dique de granito de aproximadamente $0,5 \mathrm{~m}$. de espessura, cortando as rochas blastomilonfticas. Apresenta nas suas bordas em contato com os blastomilonitos falxas es treitas, centimétricas, com textura pegmatitica. A rocha em si apresenta textura faneritica fina, inequigranular, porēm com biotitas orientadas, principalmente próximo ằs suas bor das. Como mineralogia apresenta biotita, microclíneo, quart zo, hornblenda, apatita, ortoclásio (?) e mesopertita (?).

\subsection{9-Depósitos Aluvionares}

São encontrados freqtientemente acompanhando a rede de drenagem da área depósitos aluvionares com espessura máxí ma da ordem de metros, dos quais poucos possuem extensão ma peável. Alguns depóstitos situam-se em terraços nas margens do Rio Paraíba do Sul, estando alguns metros mais altos que - nível normal da superficie do rio (Foto 4). Compõe-se ge ralmente de argilas, siltes e arelas finas. 


\section{5 - Estruturas}

3.5 .1 - Foliações

A Zona Principal de Deformação caracteriza-se por apresentar uma foliação extremamente conspicua, vertıcal a subvertical. Como estruturas penetrativas podem ser distin guidas xistosidade, foliação de transposição e bandamento cọm posicional, este último bastante desenvolvido e laminar, dan do um aspecto "fitado" às rochas blastomiloniticas (Fotos $\overrightarrow{3}$ e 6). Além disso, um sistema de fraturamento muito conspí cuo ocorre paralelamente à foliação (Foto 23).

A xistosidade ẽ dada pela orientação de grãos de biotita e de quartzo planar, e de porfiroclastos de formato alongado de feldspatos, anfibólios e piroxênios.

o bandamento composicional é conspícuo, sendo que as bandas possuem freqtentemente limites bruscos e bem defi nidos, mesmo em seção delgada. Na escala microscópica, este bandamento composicional jā foi descrito no item 3.4.1.

o bandamento composicional encontra-se na zona Principal de Deformação intensamente transposto, de tal ma neira que as rochas adquirem um padrão estrutural muito homo gêneo, sendo todas as estruturas tornadas paralelas.

Sobre estas estruturas sobrepõe-se ainda estrutú ras disruptivas, que serão analisadas adiante.

principalmente dentro da faixa mapeada como consti tuída predominantemente de blastomilonitos tipo "a", ocorrem eventualmente planos de crenulação que cortam obliquamente a foliação. Estes planos de crenulação defletem a orienta ção das lamelas de biotita, cordões de quartzo planar e a forma alongada dos porfiroclastos, permitindo inferir 0 sen tido do cisalhamento (Fotos 43 e 45 ). No entanto não foí possivel coletar medidas estatisticas das atitutes desses planos. 
A intensa foliação de transposição e xistosidade associadas tornam-se mais rarefeitas e menos conspicuas con forme se passa da Zona Principal de Deformação para as zonas transição e para os blocos adjacentes. A foliação passa a ter atitudes mais variāveis, com mergulhos variando entre

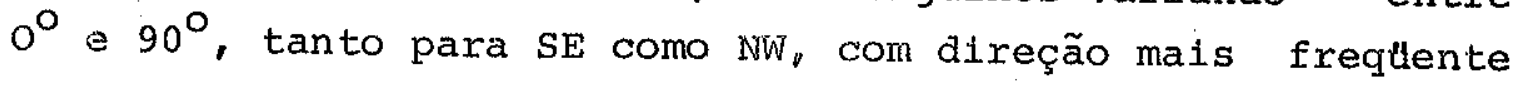
situada entre N70E e N50E. (ver Figuras 3, 4 e 5).

Nota-se com frequência, principalmente nas zonas de transição, a presença de duas foliações. Uma vertical a subvertical, devida à transposição e/ou foliação cataclästi ca, sobreposta a outra, frequentemente de mergulhos menores, correspondente a gnaissificação ou xistosidade anteriores.

As medidas de atitudes de foliação obtidas no cam po foram agrupadas em três conjuntos distintos: as dos blo cos adjacentes, as das zonas de transição e as da zona prin cipal de Deformação. Foram plotados como polos em diagramas Schmidt-Lambert (respectivamente Figuras 5, 4 e 3, com 83,105 e 101 polos cada um) e traçadas curvas de contorno de freqten cia de medidas por 1\% de área do diagrama. Como ó número de medidas em cada diagrama é pequeno, e os dados não foram co letados visando uma análise estatistica, os diagramas devem ser entendidos como de cunho meramente ilustrativo, mostrando os padrões gerais.

\section{o diagrama de polos de foliação da zona Principal} de Deformação (Figura 3), mostra uma concentração muito alta de polos (acima de 30\%), indicando que praticamente a totali dade das atitudes das foliações medidas encontra-se entre $\mathrm{N} 54^{\circ} \mathrm{E}$ e $\mathrm{N} 68^{\circ} \mathrm{E}$, com mergulho de $90^{\circ}$ a $80^{\circ}$, tanto para $\mathrm{SE}$ Co mo para NW. A única dispersaó importante observada ē de um conjunto pequeno de polos, indicando foliações com atitudes contidas entre $\mathrm{N} 31^{\circ} \mathrm{E}$ e $\mathrm{N} 06^{\circ} \mathrm{E}$, com mergulhos entre $50^{\circ}$ e $70^{\circ}$ NW.

o padrão de foliação das zonas de transição (Figụ ra 4), mostra jā alguma dispersão, principalmente nos valo res de mergulho, que podem chegar atē $20^{\circ}$, porëm assim mesmo. 
com alta concentração de pontos entre $N 57^{\circ} \mathrm{E}$ e $\mathrm{N} 68^{\circ} \mathrm{E}$, e $90^{\circ} \mathrm{e}$ $80^{\circ}$ de mergulho. Nota-se tambēm uma dispersão de atitudes de foliação no sentido anti-horärio, desde o ponto de maior concentração $\left(\mathrm{N} 62^{\circ} \mathrm{E}\right)$ atē $\mathrm{N} 15^{\circ} \mathrm{W}$. Afora o conjunto de polos que constituem esta ŭltima dispersão, pode-se tentativamente esboçar um circulo mäximo passando pelas maiores concentra ções, indicando um eixo $\beta$ com atitude $563^{\circ} \mathrm{W} 88^{\circ} \mathrm{SW}$.

Já o diagrama com os polos das foliações medidas nos blocos adjacentes (Figura 5), mostra uma razoāvel disper são, com tendência de configurar um circulo máximo com etxo $\beta$ de atitude $\mathrm{N} 68^{\circ} \mathrm{E} 74^{\circ} \mathrm{NE}$.

Apesar do nümero relativamente pequeno de dados,os diagramas mostram a grande homogeneidađe da foliação, princi palmente na Zona Principal de Deformação, sendo que, confor me se passa para as zonas de transição e para os blocos adjá centes, a dispersão aumenta, principalmente nos valores de mergulho. No entanto, a distribuição dos polos nestes dois ültimos casos sugere uma "guirlanda", com eixo $\beta$ por volta de $\mathrm{N} 65^{\circ} \mathrm{E}$, ... subhorizontal. Tambëm ocorre uma dispersão em torno de um eixo aproximadamente vertical, podendo a folia Ção atıngir direções de atē $\mathrm{N} 10^{\circ} \mathrm{W}$. No entanto, as medidas que configuram essas dispersões estão relacionadas no campo com proeminentes lineamentos de direção N/S, analisados mais adiante.

3.5 .2 - Lineações

As rochas blastomiloniticas apresentam de modo ge ral proeminentes lineações com atitude subhorizontal, contí das nos planos de foliação, estruturas estas que podem even tualmente serem observadas em outras rochas (Fotos 19 e 20).

o tipo mais comum é semelhante ao que frequentemen te se identifica como estrias de atrito em espelhos de falha. São observăveis preponderantemente em planos de fraturamen tos verticais a subverticals, planos ou suavemente curvos. 
(Foto 23). Possuem uma distribuição heterogênea, algumas ve zes concentrando-se fortemente en faixas de largura métrica. Possuem em geral grande extensão e continuidade (metros a de zenas de metros). No entanto, ocorrem basicamente em faixas quartzo-feldspātlcas, aparentando apresentar forte recrista lização de quartzo. Em toda a ärea foram coletadas 100 medi das de at1tudes dessas lineações, que foram plotadas em dia grama Schmidt-Lambert (Figura 6). Mostram uma concentração multo forte (superior a $20 \%$ por 18 da ärea) em torno da ati tude $\mathrm{N} 64^{\circ} \mathrm{E} 75^{\circ} \mathrm{E}$. Apresentam tambēm uma dispersão de $\mathrm{NE}$ atẻ $\mathrm{N} 20^{\circ} \mathrm{W}$, com as atitudes de 11 neações sofrendo rotação em tor no de um eixo aproximadamente vertical, até esta última airé ção. Como no caso das follações, estas medidas foram coletá das nas āreas de influência de lineamentos N/S (atē distân cias de metros a dezenas de metros destes).

Porfiroclastos grosseiros que dão a estrutura "flaser" dos milonttos-gnaisses tambëm constituem-se em li neações subhorizontais. Em escala microscópica nota-se que - alongamento de porfiroclastos, alinhamento de fragmentos cataclasados e sombras de pressão com associações recristali zadas em torno de porfiroclastos definem também lineações com essa atitude. Em algumas lâminas, nota-se que a sillimanita tende a aparecer preponderantemente em seções basais, ou em seções prismäticas revelando um "fabric" orientado. Seções basais de hornblenda aparecem predominantemente em cortes perpendiculares aos eixos de dobras, mostrando que os cris tais prismāticos definem lineações paralelas aos eixos de dô bras. Porēm, aparentemente, não hã padrões simples de orien tação na matriz, observãveis com inserção de lâmina de gipso no microscópio.

Eixos de dobras mesoscópicas nas rochas blastomilo niticas da Zona Principal de Deformação e de rochas das zo nas de transição e blocos adjacentes possuem tambëm atitude subhorizontal. Pela homogeneldade do padrão de dobramento na Zona Principal de Deformação os elxos de dobras podem ser. 
considerados lineações penetrativas. Onze medidas de eixo de dobras em blastomilonitos tipo "b" lançadas em diagrama (Figura 7) mostram coincidência com as concentrações mäximas das lineações do diagrama da Figura 6 , e tambëm com os eixos $B$ dos Diagramas das Figuras 4 e 5 . Ainda na Figura 7 , nota- se que uma medida de eixo de dobra em rochas carbonäticasda Zona de Transição SE coincide com as atitudes dos eixos de dobras dos blastomilonitos, enquanto que duas medidas de ei xos de dobras em quartzitos do Bloco SI divergem um pouco,com atitudes por volta de $\mathrm{N} 40^{\circ} \mathrm{E}$.

Preponderantemente na Zona Principal de Deformação observa-se feições de intensa "boudinage" (Fotos 24 a 27).

Os "boudins" constituem-se normalmente em corpos de rochas anfiboliticas, granuliticas, quartziticas ou cal cossilicatadas, em meio às rochas blastomiloníticas. Apre sentam, via de regra, estruturas, texturas e constituição di ferentes e eventualmente discordantes das rochas ao seu re dor. Observam-se tambëm estruturas de estricção ("pinch and swell") (Foto 25), ou seja, de estrangulamento e deformação plástica do corpo, sem que chegue a ocorrer a "boudinage". Quando vistos em corte horizontal, a foliação dos blastomilo nitos tipicamente contorna as formas em geral elipsoidais dos "boudins". As Fotos 26 e 27, mostram feições particular mente surpreendentes neste aspecto, notando-se que a orienta ção dos porfiroclastos também contorna o "boudin" "Boudinage" em rochas carbonāticas da zona de Transição SE tambëm foi ob servada (Foto 29). Os "boudins" são constituidos de mate rial carbonático mais puro, enquanto que o material deforma do em torno do "boudin" apresenta constituição mineralógica mais variada (calcossilicática), com minerais granulares verde escuros (provavelmente olivina). Dentro da faixa dos blastomilonitos tipo "a" foram encontrados "boudins" de milo nito-gnaisses (tipo "a"), de composição anfibolítica ou gra nulitica, apresentando por vezes foliação discordante dos blastomilonitos que o circundam (Foto 44). 
A observação de forma tridimenstonal dos"boudins" não ë muito fäcil. No entanto, dentro da Zona Principal de Deformação, observa-se que em cortes horizontais os "boudins" tem forma elipsoidal típica, com alongamento maior paralelo à foliação e o menor perpendicular a ela. Em cortes verticais no entanto observa-se que os "boudins" possuem forma mais tabular (Foto 44) sendo o alongamento maior na verda de no sentido vertical. E sendo o eixo paralelo à foliação, observado em cortes horizontais, a dimensão intermediāria. Estas observações mostram que, dentro da zona Principal de Deformação, os "boudins" definem lineações verticais. Porém com direção de estiramento horizontal, paralela à foliação e demais lineações. Nas zonas de transição e nos blocos adjacentes, os "boudins" possuem atitudes mais variāveis, ob servando-se por vezes, em corte vertical, a forma elipsoí dal típica dos "boudins" em meio à foliação subhorizontal.

Estruturas colunares observadas (Foto 28) dentro da Zona de Rochas Blastomiloniticas, definidas por superfí cies cilindricas, intensamente lineadas, também definem 1 i neações subhorizontais.

\section{5 .3 - Dobras}

As rochas blastomiloniticas da Zona Principal de Deformação possuem um estilo de dobramento bastante homogê neo na escala de afloramento. Constituí-se de dobras cerradas, com äpices espessados, frequentemente isolados em meio à intensa foliação, com flancos estirados e transpos tos (Fotos 30, 33 e 34). Apresentam plano axial vertical é eixo subhorizontal. Medidas de onze elxos de dobras em ro chas blastomiloniticas, um em rochas carbonāticas e dois em quartzitos encontram-se plotados no diagrama da Figura $7, j a ̈$ discutido no item anterior. Embora o número de medidas de atitudes de eixos seja pequeno, este padrão de atitudes dos planos axiais e eixos de dobras é inferido com bastante se gurança, pois os perfis das dobras mostram-se quase que tão 


\section{DIAGRAMAS DE IGUAL ÁREA}
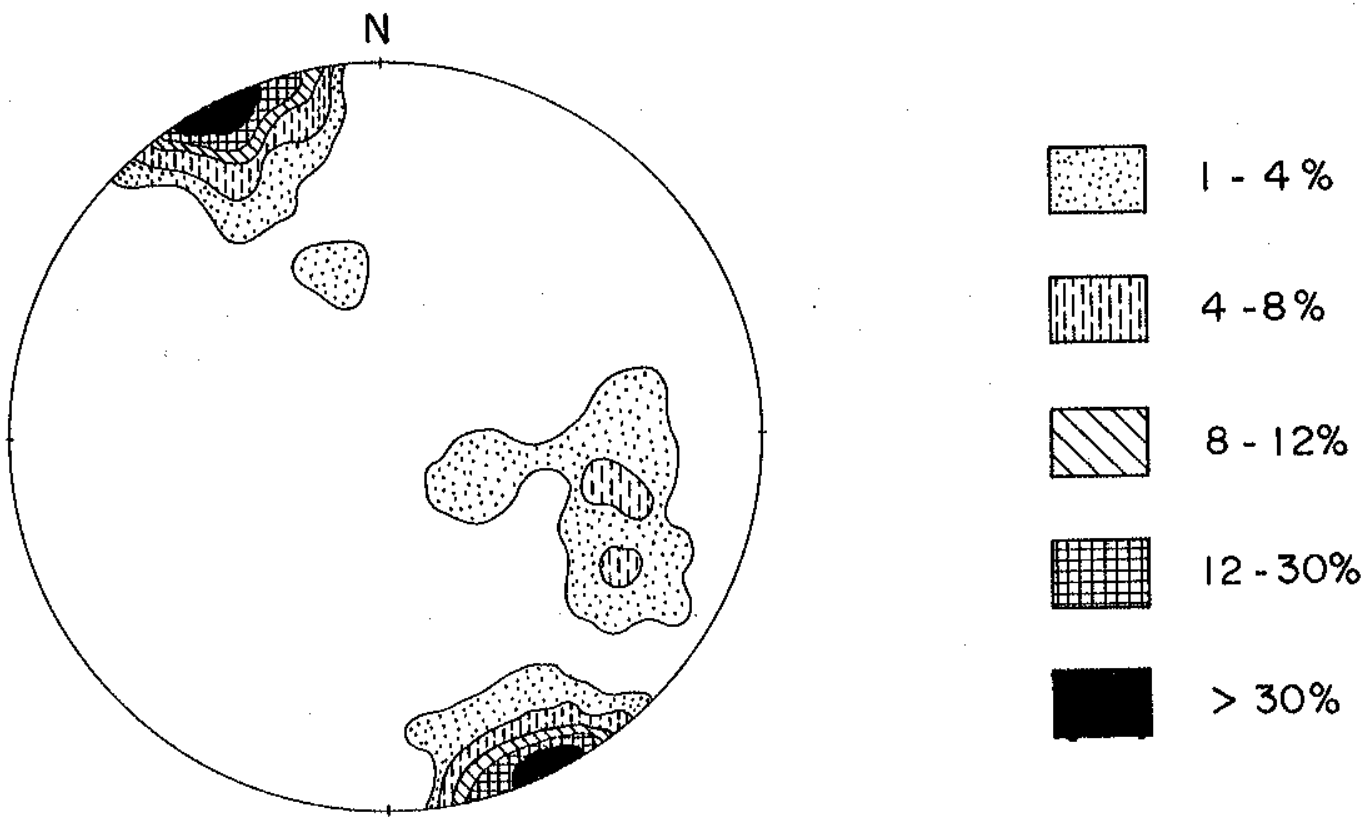

Foliaçōes

Zona principal de deformação FIGURA 3 101 medidas
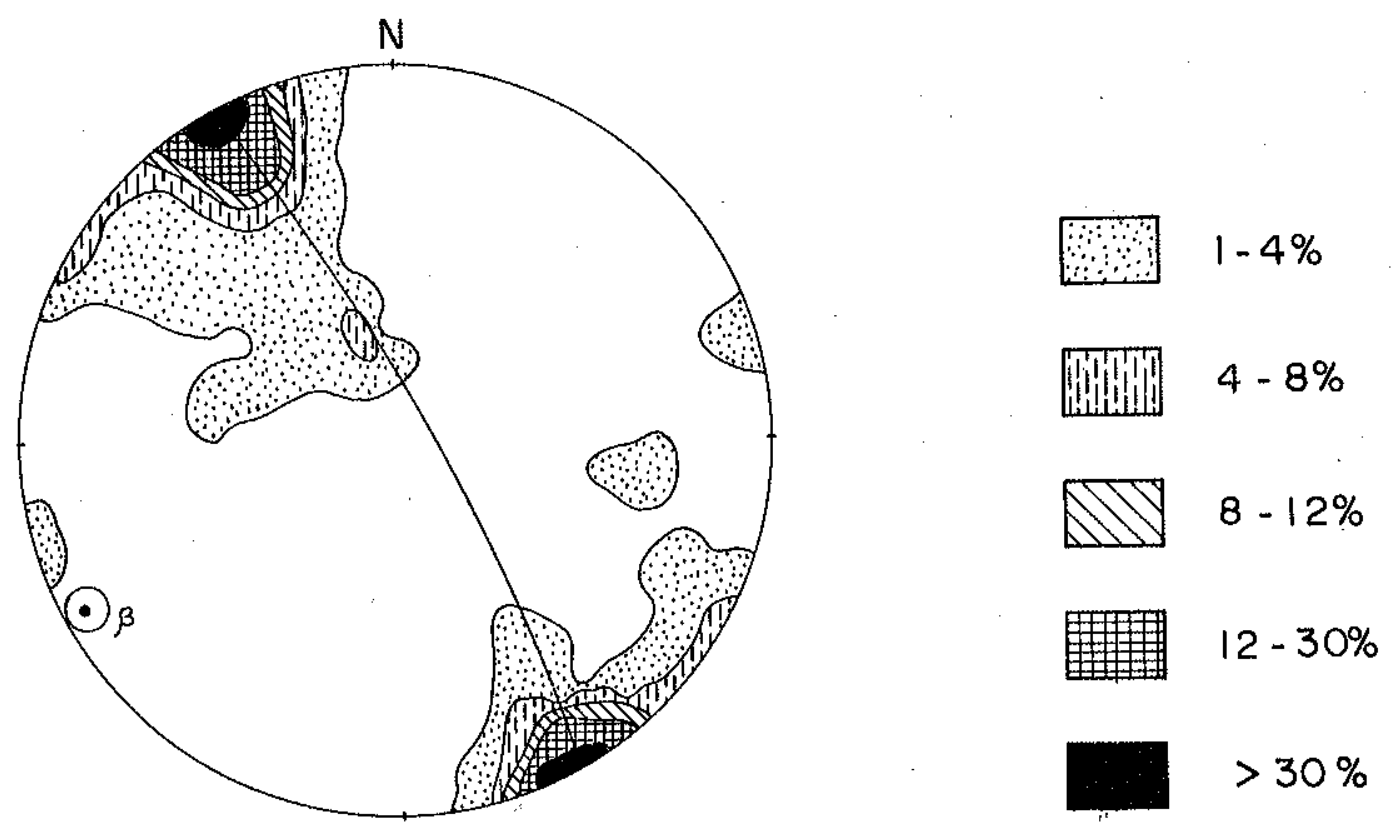

Foliacōes

Zonas de Transicão 
DIAGRAMAS DE IGUAL ÁREA

(REDE DE SCHMIDT-LAMBERT)
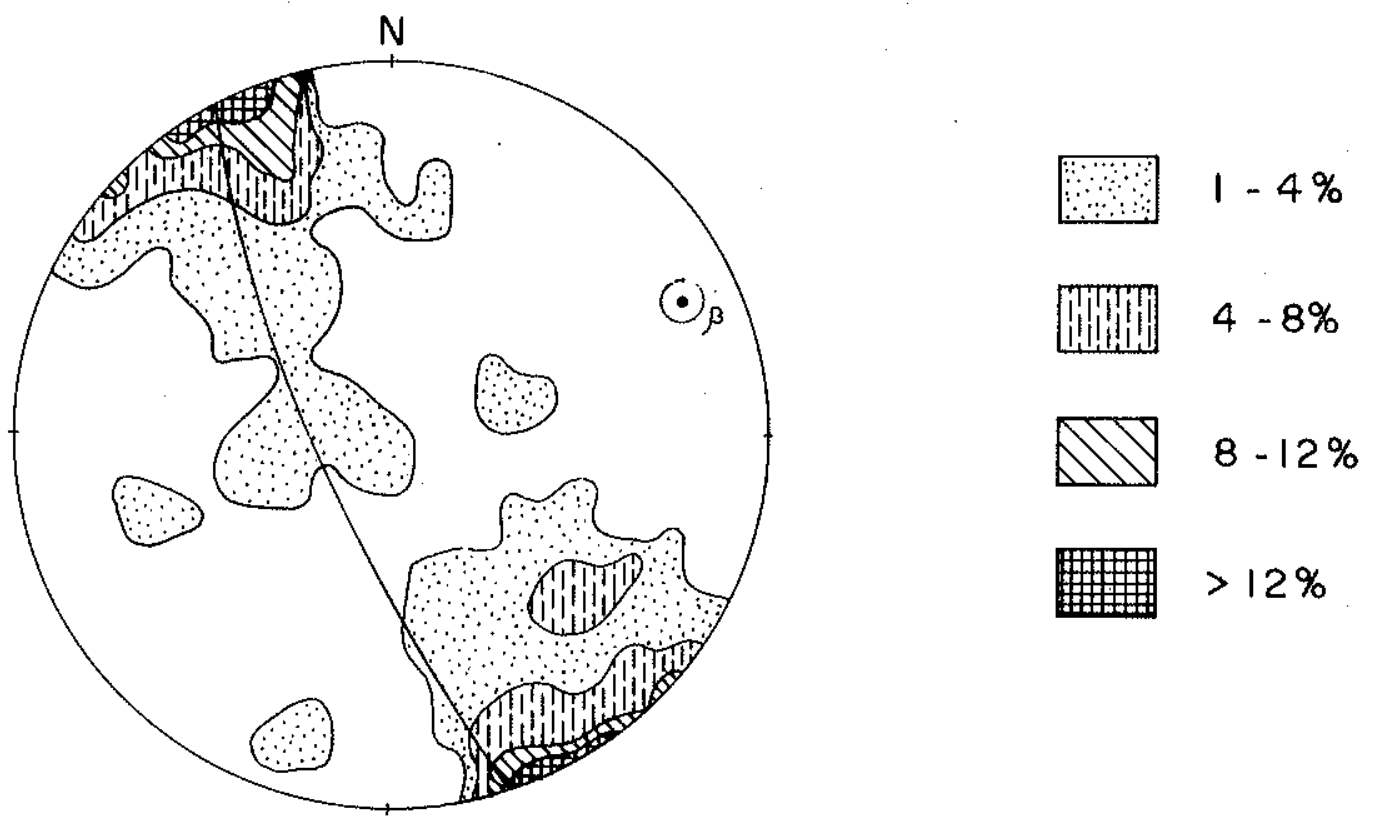

Foliaçöes

Blocos adjacentes

FIGURA 5

83 medidas

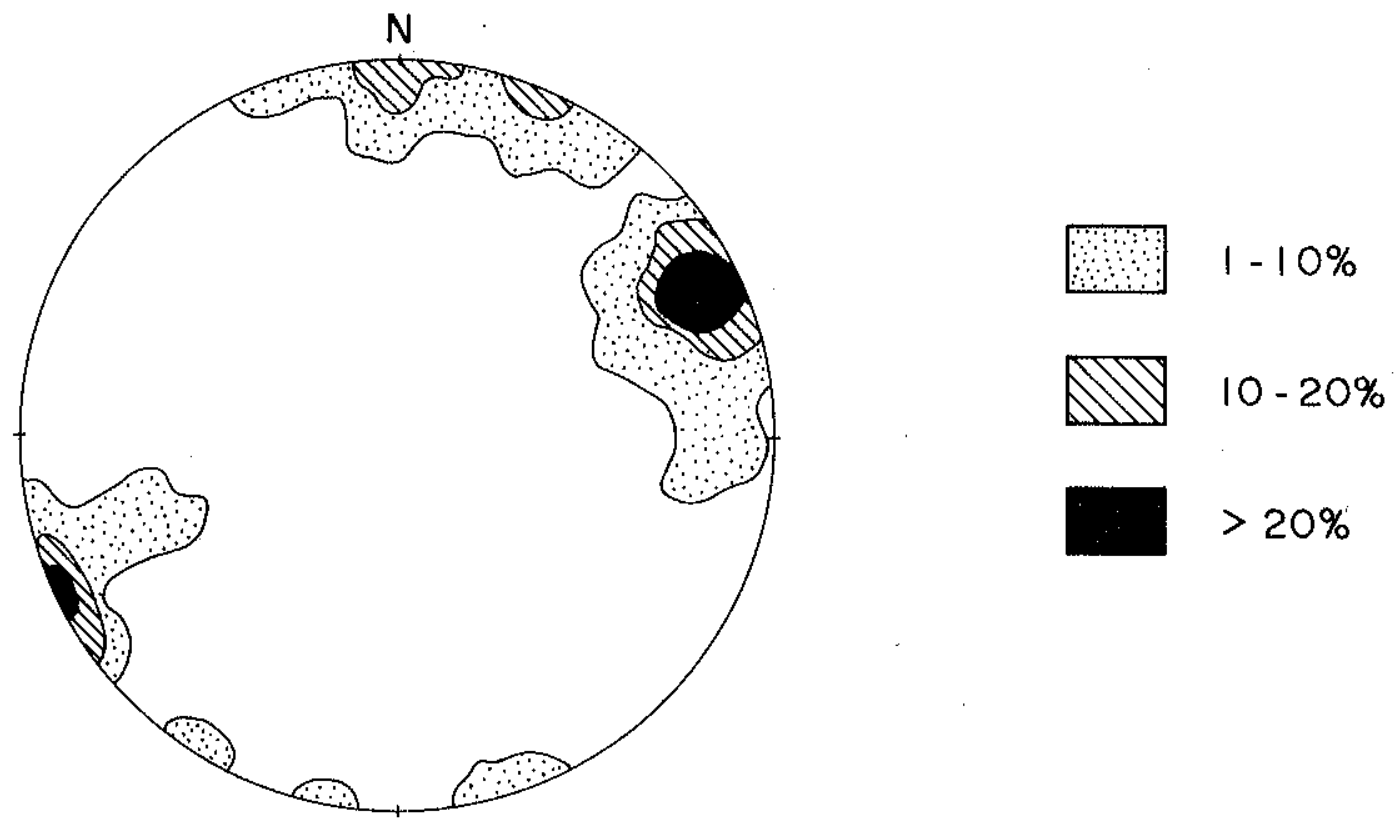

Lineaçōes

Toda área

100 medidas

FIGURA 6 


\section{DIAGRAMAS DE IGUAL ÁREA}

(REDE DE SCHMIDT = LAMBERT)

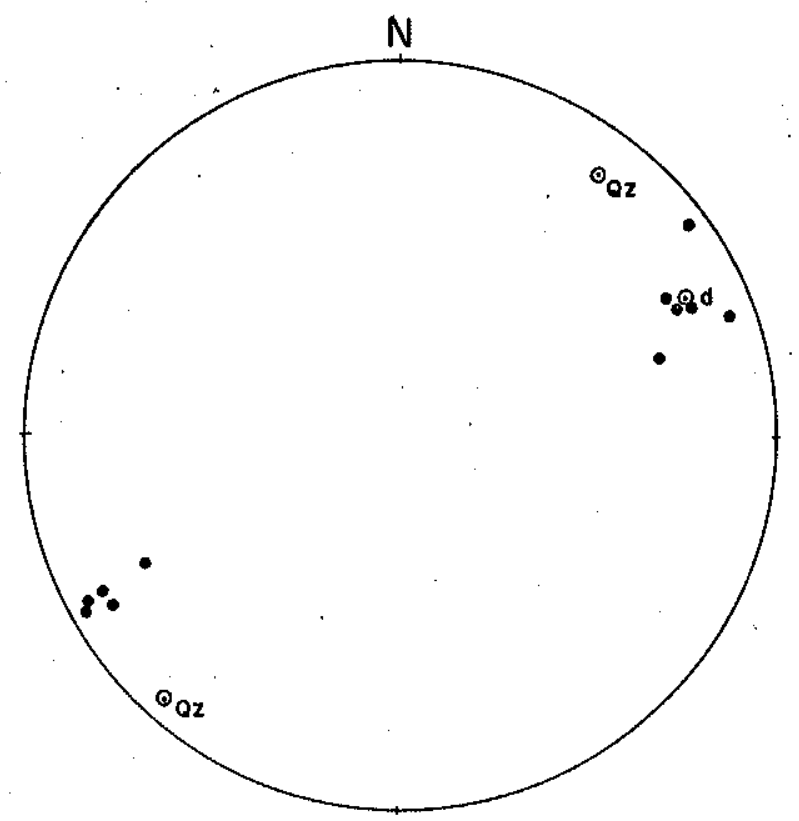

Blastomilonitos
(Zona principal de deform.)

$\odot_{Q z}$ Quartzitos (bloco SE)

od Dolomitos (zona transiçāo SE)

Eixos de dobras

14 medidas

FIGURA 7
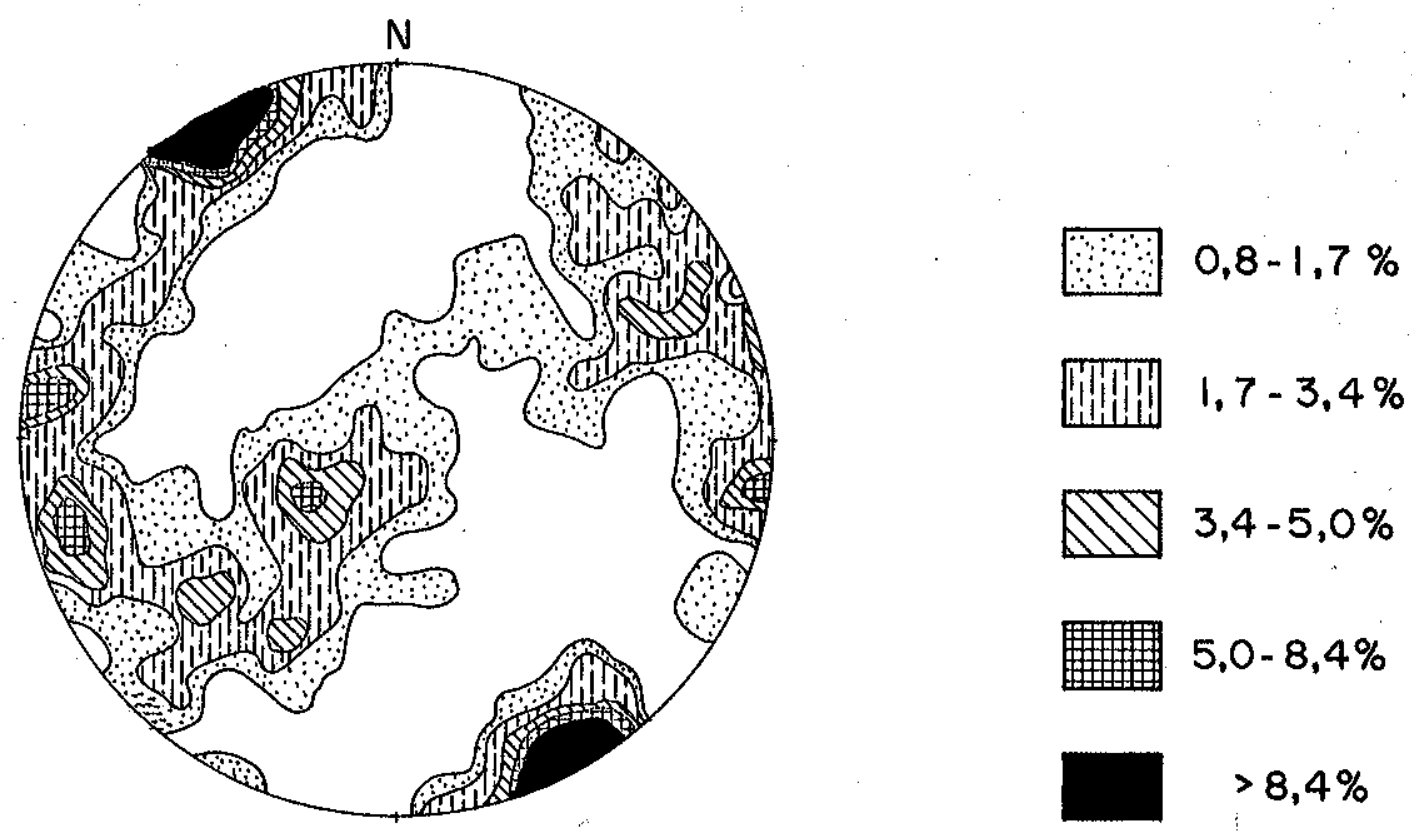

Juntas

119 medidas 
somente em cortes verticais, sendo que em cortes horizon tais observa-se em geral somente a intensa foliação, ou en tão perfis aparentes de ápices de dobras multo fechadas e alongadas, indicando dobras com eixo subhorizontal, observa dos em corte situado em plano subparalelo ao eixo. Em al guns locais apresentam em perfil caracteristicas tipicas de dobras de fluxo, com äplces bastante espessados, mas em ou tros apresentam características de dobras angulares, com ápices fechados e agudos, crenulados no sentido vertical. A 1 guns perfis de dobras sugerem feições de redobramento, como na Foto 34, porēm as evidências disso não são claras. A den sidade de planos de transposição varia, obscurecendo fré qülentemente todas as outras estruturas. Este estilo de do bras e transposição evidencia um forte processo de achata mento dessas rochas, na đireção perpendicular aos planos axiais das dobras e planos de transposição.

Este dobramento e transposição efetua-se sobre o bandamento composicional das rochas blastomiloniticas. Even tualmente, observa-se em algumas seções delgadas que a fo liação dada pela orientação das lamelas de biotita e pelo quartzo planar é oblíqua ao bandamento composicional, indi cando que este está dobrado.

Selecionou-se amostras que contivessem āpices de dobras nas rochas blastomiloniticas. Foram então feitos cortes e seções delgadas em três planos perpendiculares en tre si, de modo que para um mesmo ponto tivessemos uma lâmi na perpendicular ao eixo de dobra e ao plano axial (paralé lo ao perfil da dobra), uma paralela ao eixo e perpendicular ao plano axial, e outra paralela ao plano axial (Figura 9). Por esta tēcnica também foram feitas seções delgadas em flan cos de dobra.

Da anālise textural de äpices de dobras nas ro chas blastomiloniticas, algumas conclusões podem ser traçâ das.

Em primeiro lugar, observa-se que o dobramento e. 
transposição efetuam-se sobre o bandamento composicional das rochas blastomiloniticas. Nos blastomilonitos mais finos e homogêneos, este bandamento apresenta-se como variações na quantidade de biotitas. Em milonito-gnaisses grosseiros, ob servam-se bandas, às vezes com contatos bruscos e bem defí nidos, de associações distintas de porfiroclastos (Fotos $3 \overline{5}$ a 40).

Observa-se também que os porfiroclastos definem lineações paralelas aos eixos das dobras.

o quartzo planar e as lamelas de biotita definem uma foliação plano axial. o quartzo planar ë observado ape nas em algumas bandas, interrompendo-se no contato entre elas, indicando que sua formação se deu apenas dentro das bandas com composição adequada (Foto 35 ).

Em algumas seções delgadas de blastomilonitos da Zona Principal de Deformação nota-se que a foliação dada pe las biotitas e quartzo planar, estabelecida como plano axial, está crenulada em direção oblíqua a ela (Foto 43). Em algu mas lâminas de amostras de faixa de blastomilonitos tipo"a", nota-se que os cordões de quartzo estão deformados, apresen tando extinção ondulante (Foto 42).

o estilo de dobramento e transposição observado na Zona Principal de Deformação torna-se menos denso conforme se passa para as zonas de transição e para os blocos adja centes. Aí são encontradas dobras e transposições com estí lo semelhante, porém com atitudes de plano axial mais variá veis, com mergulho desde vertical até cerca de $30^{\circ}$, para NW ou SE e com padrão de ocorrência bem menos denso. Em quart zitos do Bloco SE, em rochas das zonas de transição e em gnaisses bandados do Bloco NW, observou-se que ocorre outro tipo de dobras, em geral recumbentes, com plano axial hori zontal a subhorizontal, mergulhando tanto para NW como para $\mathrm{SE}$, e com eixos subhorizontais (Foto 31). Este dobramento afeta bandamento composicional dessas rochas, e possivelmen te neossomas. Em alguns locais, observa-se claramente que. 
se sobrepõe a ele a foliação (xistosidade) subvertical e transposição relacionadas ao primelro tipo de dobras descri to (Foto 32).

No Bloco SE foram mapeadas sinformas e antiformas matores em escala macroscópica cujos eixos aproximados estão indicados no mapa geológico (Anexo 3). As evidências utılizađas para ldentificā-las foram basicamente atitudes de fo liação e das dobras menores. No Bloco NW os dados coletados não permitiram delineā-las, sendo as feições desenhadas nos perfis geológicos apenas de cunho ilustrativo (embora não dis cordantes das medidas tomadas). Isto não significa no entan to que não seja possível identificar mais estruturas desse tipo na área, com uma coleta de dados mais detalhadas nos blocos adjacentes.

\section{5 .4 - Estruturas Disruptivas}

Em escala de afloramento, as principais estrutü ras disruptivas observadas relacionam-se a um denso sistema de fraturamento paralelo à foliação. Com frequência, um pa drão bastante denso de lineações dentro desses planos sugere a aparência de "espelhos de falha", devidos ao atrito entre blocos que sofreram movimentos diferenciais. Porēm conforme jā indicado no item 3.5.2, essas lineações mostram por vezes feições de recristalização. Esse sistema de fraturamento re corta toda a Zona Principal de Deformação, assim como as zo nas de transição, sendo observados esparsamente nos blocos adjacentes. No entanto, a densidade com que ocorrem não é uniforme, estando concentrados em certas falxas; da ordem de metros a dezenas de metros.

Sistema de juntas sobrepõe-se a toda a ārea, sen do no entanto particularmente bem desenvolvido em blastomiló nitos finos, quartzosos e homogêneos, em geral tipo "a". So bre dols afloramentos deste tipo de rochas foram coletadas 119 medidas de atitudes de juntas, plotadas como polos em diagrama schmidt-Lambert '(Figura 8). O conjunto de juntas. 

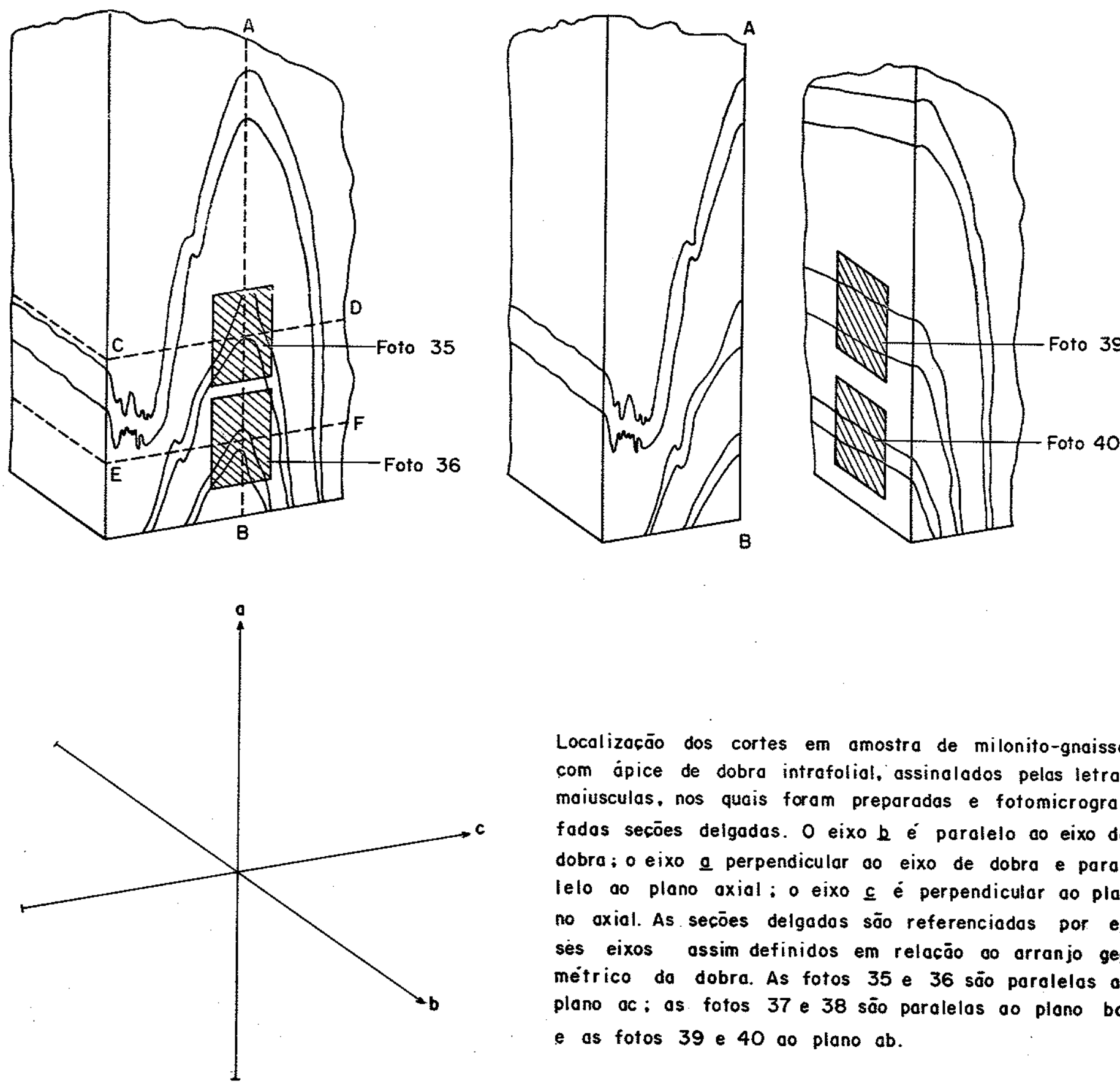

Localizacāo dos cortes em amostra de milonito-gnaisse com apice de dobra intrafolial, assinalados pelas letras maiusculas, nos quais foram preparadas e fotomicrografados secōes deigados. O eixo $\mathrm{b}$ é paralelo to eixo de dobra; o eixo a perpendicular oo eixo de dobra e paralelo ao plano axial: o eixo $\subseteq$ é perpendicular ao plano axial. As secōes delgadas são referenciadas por es ses eixos assim definidos em relacōo oo arranjo geg métrico da dobra. As fotos 35 e 36 säo parolelas 00 plano ac: as fotos 37 e 38 sāo paralelos ao plano bc e as fotos 39 e 40 ao plano ab.

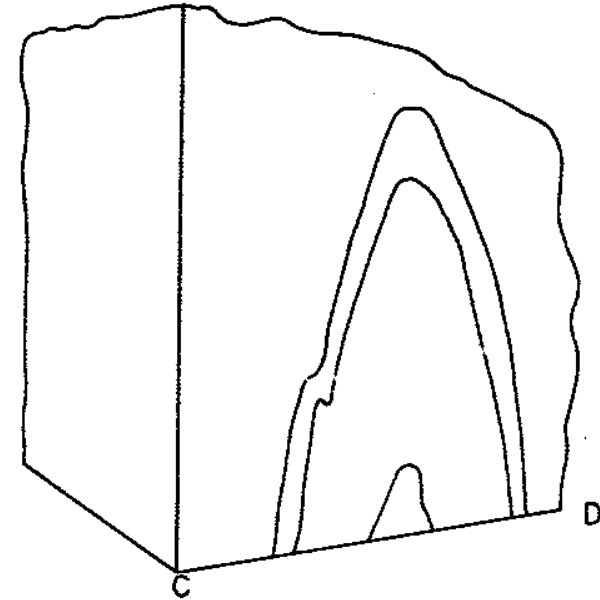

Foto 37

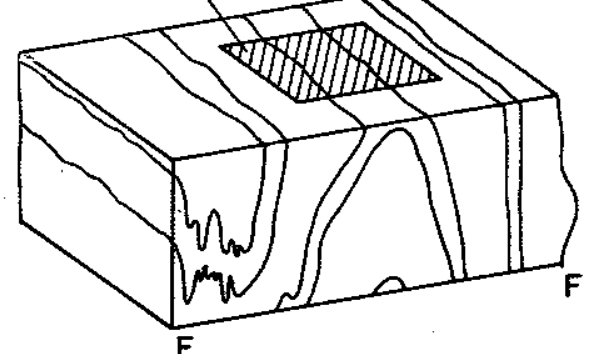

Foto 38

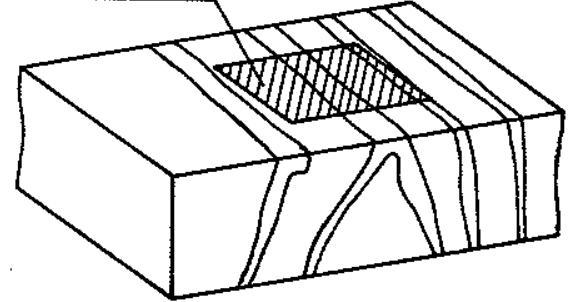

FIGURA 9 
que nitidamente sobressai em relação aos demais é vertical e paralelo à follação, com māximo a $N 60^{\circ} \mathrm{E} 90^{\circ}$. Afora estes, destacam-se dois conjuntos com atitude subvertical, obliquos à folliação (N08 ${ }^{\circ} \mathrm{E} 80^{\circ} \mathrm{SE}$ e $\mathrm{N} 15^{\circ} \mathrm{W} 80^{\circ} \mathrm{NE}$ ) e um subhortzontal, perpendicular à follação $\left(\mathrm{N} 35^{\circ} \mathrm{W} 25^{\circ} \mathrm{NE}\right)$. Além disso,ocorrem medidas mais dispersas, porēm tendendo a configurar um cin turão com atitudes aproximadamente perpendiculares à folla ção e mergulho de $0^{\circ}$ a $90^{\circ}$, tanto para $\mathrm{NE}$ como para $\mathrm{SW}$, apre sentando dois máximos a $N 40^{\circ} \mathrm{W} 55^{\circ} \mathrm{NE}$ e $\mathrm{N} 30^{\circ} \mathrm{W} 70^{\circ} \mathrm{SW}$, e um má ximo mais deslocado, a $\mathrm{N} 60^{\circ} \mathrm{W} 50^{\circ} \mathrm{NE}$.

Na topografia e drenagem, ressalta-se bastante 0 conjunto de juntas paralelo à follação $\left(N 60^{\circ} \mathrm{E} 90^{\circ}\right)$ e o perpendicular a esta (provavelmente com o máximo a $\mathrm{N} 30^{\circ} \mathrm{W} 70^{\circ} \mathrm{SW}$ ). A drenagem mais fina apresenta um padrão em treliça já des crito, sendo condicionado por esse sistema de juntas. Po rëm sobre a ärea desenvolve-se tambëm um conspícuo sistema de lineamentos morfológicos bastante longos, com quilôme tros de extensão, facilmente identificáveis em mapas topo gräficos, fotografias aéreas e imagens de satēlite. Um con junto mals continuo é paralelo à foliação, desenvolvenđorse principalmente dentro da Zona de Rochas Blastomiloniticas,e outro é oblĩquo a esta, com direções $\mathrm{N} 15^{\circ} \mathrm{W}, \mathrm{N} / \mathrm{S}$ e $\mathrm{N} 10^{\circ}-15^{\circ} \mathrm{E}$.

Este último conjunto de lineamentos, com dire ções em torno de $\mathrm{N} / \mathrm{S}$, destaca-se em relação às demais estrú turas por ser oblíquo à foliação. Apresentam, quando obser vados na escala 1:50.000, extensões de poucos quilômetros. Porém quando observados em escala menor, como em imagens de satēlite ou radar, os vărios segmentos unem-se, formando lineamentos com dezenas de quilômetros de extensão, na altụ ra da cidade de Três Rios (ver Anexo 4). Certas feições mor folögicas nas suas proximidades sugerem inflexões na folia ção.

Embora facilmente evidenciäveis em fotos aẻreas e imagens de satélites, säo no entanto. difíceis de obser var no campo, pelo fato de constituirem frequentemente va 
les alongados e retilineos, recobertos por aluviões. Nos ra ros locais em que afetam rochas aflorantes, observa-se que constituem-se de faixas estreitas de rochas com foliações pa ralelas à sua direção, produzindo inflexões na foliação das rochas blastomiloniticas (ou de outras rochas que cortem), numa distância de metros a dezenas de metros. Tratam-se de zonas de cisalhamento, que podem ser caracterizadas como fa lhas transcorrentes sinistrais, com rejeitos minimos da or dem de metros a dezenas de metros (Figura 10). Pela amplitú de relativamente pequena desses rejeitos, são dificilmente representáveis na escala adotada (1:50.000). Quando tais fei ções foram observadas no campo (pelo menos inflexões bruscas na foliação até perto da atitude $\mathrm{N} / \mathrm{S}$ ), foram indicadas no ma pa como "falhas observadas" na extensão total do lineamento observāvel em fotos aēreas. Quando só foram observadas em fotos aēreas e mapas, foram indicadas como "falhas proväveis". o estilo de deformação observado (de inflexão e produção de uma nova foliação e/ou rotação da antiga) sugere que proces sos de caráter dúctil predominaram na formação dessas estrú turas. As inflexões mostradas na foliação e lineação, de $\mathrm{N} 54^{\circ} \mathrm{E}$ até $\mathrm{N} 20^{\circ} \mathrm{W}$ (ver figuras 3 a 6 ), estão relacionadas a es te sistema de falhas transcorrentes menores, tendo sido as medidas de atitudes coletadas nas suas äreas de influência. Nota-se que as foliações tendem a ter mergulho alto para Oes te indicando que o plano de falha não è perfeitamente vertí cal. E as lineações tendem a mergulhar para $\mathrm{NE}$ e $N$. Num dos afloramentos observa-se a ocorrência de pegmatitos no plano de falha e de dique de granito próximo a ele (ver item $3.4 .8)$

Dentro da ārea mapeada não foram encontradas eviđên cias de falhamentos normais. A ocorrência destes é sugerida pelo relevo escalonado observado na zona Principal de Defor mação (ver item 3.3). Os terraços aluvionares pouco mais altos que o nivel do Rio Paraíba do Sul poderiam também ser devidos a movimentos verticais, ou então ao rebaixamento do nivel de base do rio. Foram encontradas lineações com for te mergulho apenas fora da ārea de detalhe, próximo a Areal, no alinhamento da represa de Morro Grande. 


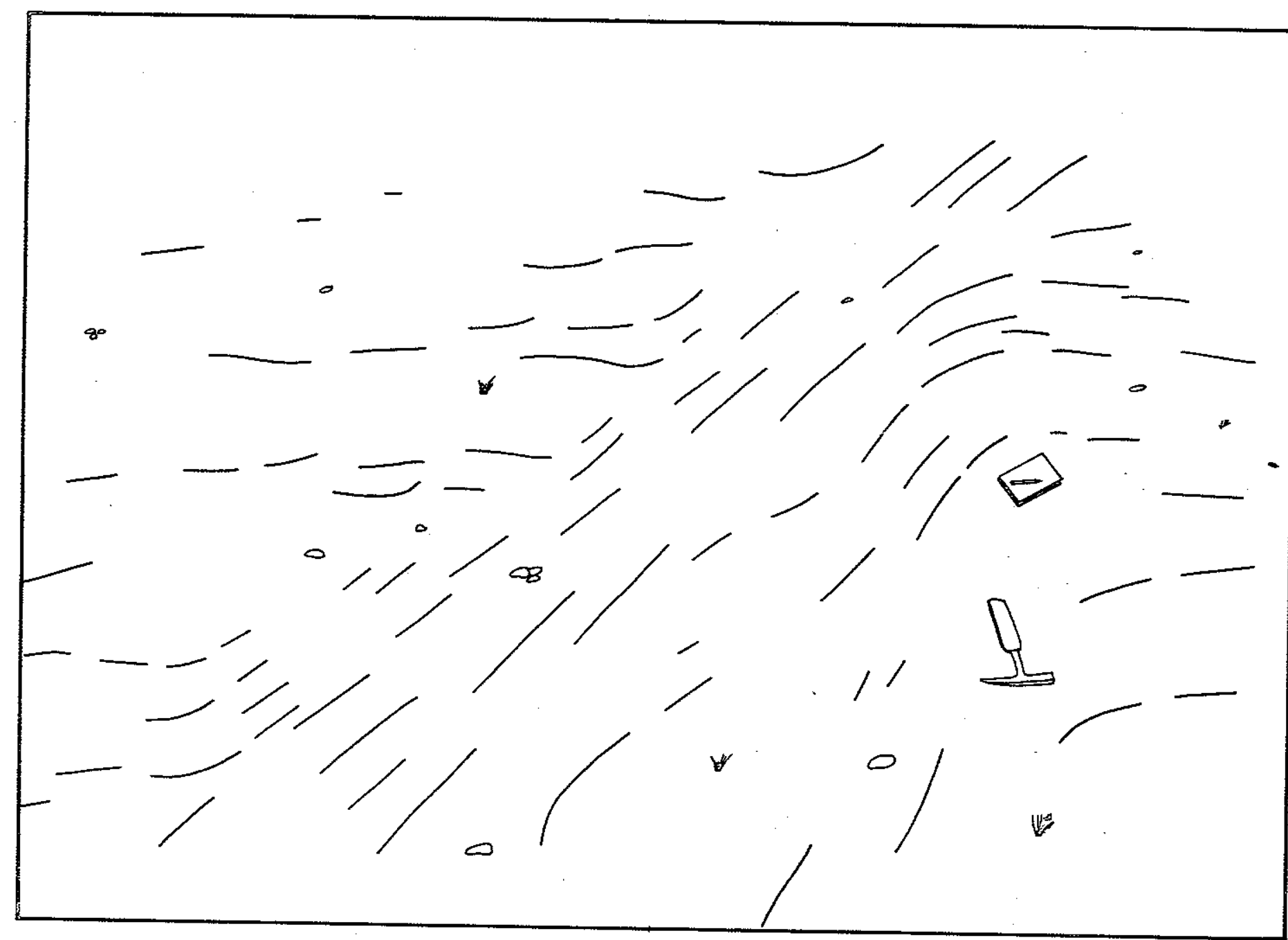

FIGURA 10 - Zona de cisalhamento em escalo de afloramento, correspondente a falho transcorrente sinistral de direção NNW, defletindo a foliação das rochas blastomiloniticas. 
Foi observada em pedreira abandonada de dolomito, falha de empurrão de dimensões métricas, com descolamento na base, provocando deformações plásticas no bloco cavalgante (Foto 41). A mesma indica cavalgamento para o quadrante sul. No entanto, não foi possivel determinar-se mais precisamente sua atitude e continuidade, assim como relação com outras es truturas.

Certos contatos entre unidades da zona Principal de Deformação e das zonas de transição são bruscos na escala de mapeamento $(1: 50.000)$, sendo marcados por depressões reti lineas na morfologia, por vezes persistentes por muitos qui lômetros. Em alguns locais estes contatos são caracterizá dos por uma alta densidade de lineações e/ou blastomilonitos de granulação fina (tipo "a"). Particularmente na faixa mais larga de ocorrência dos blastomilonitos tipo "a", situada a margem direita do Rio Paraíba do Sul, a montante de Três Rios, e atravessando a porção sul dessa cidade (vide esboço geológico), certos tipos de feições podem ser mais claramen te observados. Observa-se, particularmente no perfil da es trada que contorna Três Rios pelo Leste; indo-se de sul para Norte, milonito-gnaisses grosseiros, foliados, dobrados e transpostos, que passam para blastomilonitos quartzosos, mui to finos (tipo "a"), sem dobras ou transposições visiveis. Esses ültimos englobam "boudins" de milonito-gnaisses mais grosseiros, de coloração escura, com dobras e transposições (Foto 44). Estas feições repetem-se tambēm em outros aflora mentos dessa faixa, sendo observãveis tambēm intercalações é "boudins" de anfibolitos e granulitos básicos. Estes dados sugerem que se trate de faixas de maior taxa de deformação, ou faixas onde se concentraram os movimentos transcorrentes posteriores, como é discutido no item 3.7 .

3.6 - Migmatização

Dentro da área pode ser observada desde migmatiza 
Ção intensa, como no Bloco SE e porção norte do Bloco NW, atē incipiente, como na Zona de Rochas Blastomiloniticas e por ção sul do Bloco NW.

Na Zona Principal da Deformação observa-se que uma migmatização, em geral incipiente, afeta os blastomiloni tos tipo "b" e rochas granuliticas. Nos milonito-gnaisses ti po "a" é rara, e nos blastomilonitos tipo "a" inexistente. Apresenta-se sob diversas formas. A mais notävel é aquela que penetra pelos planos de transposição, em bandas milimê tricas a decimétricas (Foto 46). Também encontram-se bandas leucocráticas com aparência de neossomas dispostos paralela mente ao bandamento dos blastomilonitos, inclusive acompá nhando o perfil de dobras (Foto 46), e cortados pelos neos somas que penetram pelos planos de transposição. porëm em escala microscópica, não apresentam características textu rais de neossomas (ver MEHNERT, 1968, cap. 3).

Encontra-se também neossomas configurando estrutü ras agmatiticas (Foto 49), com paleossomas granuliticos. En contram-se tambëm neossomas irregulares, em foram de bolsões e neossomas difusos (Foto 48), dando um aspecto granitizado e homogêneo à rocha, às vezes bastante difícil de se discer nir das feições originadas pela deformação intensa. Em esca la de afloramento, alguns neossomas, mesmo entre aqueles que penetram pelos planos de transposição, apresentam-se linea dos e com texturas de deformação (Foto 47 ).

Microscopicamente, os neossomas apresentam textú ras granoblāsticas, grosseiras, equigranulares, em geral com algumas evidências de deformação, na forma de grãos maiores, com extinção ondulante, geminações encurvadas, separados por intersticios preenchidos por matriz recristalizada, com tex turas poligonais, e eventualmente quartzo com forma planar. pouco desenvolvida. No entanto essas feições são pox vezes muito incipientes, e nota-se em algumas lâminas que o paleos soma apresenta feições de deformação mais conspicuas (Foto 50) . Nos neossomas encontramse mais frequentemente quartzo, plagioclásio, microclíneo, encontrando-se também biotita, mus 
covita, apatita e opacos. Eventualmente observa-se melanos somas, constituidos de faixas estreitas de biotita orlando os paleossomas. Nota-se tambëm em algumas lâminas porfiro clastos de hiperstênio (e granada ?) em meio ao leucossoma.

No Bloco NW essa migmatização afeta gnaisses ban dados, com neossomas penetrando tanto pela foliação como obli quamente a ela. Formam normalmente pequenas faixas milimé tricas a centimētricas, mas eventualmente formam também "bol sões" maiores, da ordem de metros de largura. Esses gnais ses bandados passam para granitöides e nebulitos na porção NW da ärea mapeada, aparentemente pelo incremento da migmatização.

Feições como estas são tambēm comuns nas zonas de transição, afetando os milonito-gnaisses e outras rochas.

Migmatização intensa e anataxia são difundidas principalmente no Bloco SE, sendo que os corpos de quartzi tos atuaram como "resisters" à anatexia, apresentando tran sições continuas para os migmatitos através do incremento dá quantidade de feldspatos e micas. Os neossomas apresentam texturas granoblāsticas, grosseiras, com plagiocläsio, micro clineo, quartzo, biotita e hornblenda, eventualmente com mus covita resultante da alteração de biotitas.

\section{7 - Evolução Estrutural e Metamörfica}

A ārea estudada apresenta padrão estrutural que evidencia sua evolução polifásica. Como mostrado por ANTHONIOZ (1971), as rochas blastomiloniticas apresentam uma textura dual típica. A fração de porfiroclastos representa a paragênese da rocha original, e a matriz (mesostase) re flete as condições em que se deu o processo blastomiloniti co. No caso da ărea de Três Rios, uma paragênese original de fäcies granulito sofreu intenso retrabalhamento e meta morfismo retrógrađo na fácies anfibolito alta.

A homogeneidade do estilo estrutural nas rochas blastomiloniticas ë marcante. Todas estruturas lineares e 
planares penetrativas são paralelas entre si.

Nos blocos adjacentes e nas zonas de transição ob servam-se evidências de dobramento pelifástco. Nessas äreas o dobramento cerrado, com planos axiais verticais e flan cos transpostos, sobrepõe-se a pelo menos uma fase antertor de dobramento recumbente.

Por outro lado os restos de paragênese de fácies granulito são encontrados com frequência apenas dentro da Zona das Rochas Blastomiloníticas, não sendo encontradas no Bloco SE, e duvidosamente no Bloco NW, na forma de ban das em gnaisses e migmatitos. As rochas caracteristicas des se fácies provavelmente foram embutidas dentro da zona de Rochas Blastomiloniticas por processos tectônicos.

As texturas microscóplcas observadas, que podem ser sintetizadas como compostas de grandes cristais reli quiares altamente deformados, em meio a matriz recristali zada com texturas poligonais, podem ser explicadas por ou tros mecantsmos que não a deformação rüptil. Diversos au tores, em trabalhos relativamente recentes, tem demonstrado que processos combinados de deformação dūctil do retículo cristalino, recuperação ("recovery"), e recristalização po dem produzir essas texturas, tipo "miloniticas". o reticu lo cristalino, submetido a um campo de esforços dirigidos, pressão confinante e temperatura relativamente baixa, rea giria a essas condições aumentando sua densidade de distor ções e defeitos cristalinos. Sob ação de evento térmico simultâneo ou posterior, o retículo cristalino tenderia a se rearranjar, adquirindo uma configuração energētica mais estāvel (processo de recuperação). Os grãos orłginais de formados seriam então subdividłdos em subgrãos. Com a per manência ou incremento da temperatura, os subgrãos forma riam novos grãos, com bordas de equilíbrio bem desenvolví das e texturas poligonals (processo de recristalização). As feições "cataclāsticas" observadas, tipo extinção ondulante, geminações e clivagens encurvadas, microgranulação de borda. 
de grãos (textura em moldura), forma elipsoidal dos grãos maiores deformados e transformações mineralögicas podem ser explicados por mecanismos deste tipo (vide TURNER \& WEISS, 1963; RAMSAY, 1967; SPRY, 1969; BELL \& ETHERIDGE, 1973;TULLIS et al., 1973; HOBBS et al., 1978.

A origem do quartzo planar é normalmente explicada por deformação intensa de grãos anteriores de quartzo. o me canismo mais provāvel seria pela formação de lamelas de defor mação (porções planares e estreitas dentro de um grão, com ex tinção e/ou outras propriedades öpticas diferentes das porr ções do grão ao seu ređor), ao longo das bordas das quais hâ veria tendência a ruptura e formação de subgrãos e novos grãos. A tendência seria então a formação de agregados planares de grãos de quartzo deformados. No caso das rochas blastomilo nIticas de Três Rios, nota-se que o quartzo planar está total mente recristalizado, isento em geral de feições de deforma ção. Inclusões retilíneas dentro de cada grão indicam provavelmente as bordas do agregado anterior deformado. Estas fei ções de ausência de deformação são explicãveis por processos de recuperação e recristalização do retículo deformado, na presença de calor durante a deformação ou por evento termal posterior.

Tanto a migmatização como o metamorfismo retrógra do de fäcies granulito para anfibolito implicam em reações mineralögicas que necessitam de āgua (vide WINKLER, 1977). E possivel que a deformação intensa das rochas anteriores de fäcies granulito tenha facilitado a ação da āgua e as trans formações mineralōgicas, as quais promoveriam uma grande duc tibilidade do material, propiciando uma deformação ainda maior, como sugerido por WATSON (1973), para estruturas seme lhantes ao Lineamento de Alēm Paraíba.

A predominância de condições de deformação dūctil, as feições que indicam forte achatamento, as inflexões obser vadas em escala regional e a foliação intensa na zona central do Iineamento de Alëm Paraíba ajustam-se muito bem ao modelo 
de uma zona de cisalhamento ("shear belt") de RAMSAY \& GRAHAM (1970). Estes autores tambëm demonstraram que nas zo nas de cisalhamento a xistosidade não se desenvolve parale lamente às paredes da zona ou à direção de cisalhamento, mas sim paralelamente ao plano principal do elipsóide de deforma ção, perpendicularmente à direção de maior encurtamento.

Normalmente admite-se que estruturas "cataclästi cas" como as observadas sejam devidas a processos de cisalha mento. Porëm, TULLIS, CHRISTIE \& GRIGGS (1973), em estudo experimental de deformação de quartzitos, observaram que as texturas e foliação miloniticas poderiam tanto se originar por cisalhamento simples, como tambëm por compressão axial, perpendicular à direção de achatamento, em experimentos onde não hä componente rotacional, sendo as microestruturas idênticas em todos aspectos. Outros autores, como EBBLIN (1974) e WATSON (1973), tambëm tem observado feições ligadas a pro cessos de achatamento neste tipo de rochas. Estas idéias, aplicadas às rochas blastomiloníticas do Lineamento de Além Paraíba, implicariam num modelo extremamente simples de in terpretação, embora não ortodoxo, no qual todas texturas e estruturas observadas seriam devidas à esforços normais de compressão, perpendiculares aos planos axiais das dobras e à intensa foliação dessas rochas.

Porēm, o paralelismo sobre grandes äreas entre os eixos de dobras e estruturas que indicam estiramento, tais como "boudins" e lineações minerais, ou seja, ao eixo. de maior extensão do elipsóide de deformação, não é esperâvei teoricamente (HOBBS et al., 1976, pặg. 283). Uma explicação oferecida, particularmente para o caso de zonas miloniticas, seria de que as dobras fossem anteriores ou mesmo contempo râneas ao falhamento, porëm não paralelas ao eixo de maior extensão. A intensa deformação dentro da zona de cisalha mento reorientaria as dobras até um paralelismo aproximado com esta direção (op. cit., pãg. 286). No Lineamento de Alëm Paraỉba, isto é, sugerido pela ocorrência de dobras e 
"boudinage" nos blocos adjacentes e nas zonas de transição com estilo semelhante ao da zona principal de deformação, porēm com atitudes mais variáveis. Tais estrututas teriam sido rotacionadas e paralelizadas pelo cisalhamento, dentro da Zona Principal de Deformação.

Este paralelismo poderia tambëm ser explicado pela reorientação das estruturas de estiramento pelo dobramento e transposição, que seriam posteriores. Ou seja, poder-se-ia imaginar um evento de falhamento antigo, produzindo feiÇões cataclāsticas, que seriam reorientadas e recristaliza das posterlormente.

Algumas evidências sugerem que estes processos na verdade foram simultâneos. Os porfiroclastos das' rochas blastomiloniticas são contornados pela xistostdade da matriz e pelo quartzo planar. Isto mostra que a formação do quart zo planar, o desenvolvimento da xistosidade e a deformação dos grãos originais de que resultaram os porfiroclastos fo ram simultâneos. Por outro lado, a posição plano axial da xistosidade e do quartzo planar mostram que estes formaram-se durante o dobramento.

Um outro modelo que pode explicar vārias feições observadas seria de que o carãter da deformação variou de ma neira contínua com o tempo, em função do incremento da tempe ratura e/ou pressão confinante. Ter-se-ia condições de de formação rúptil predominantes no inf́cio, passando a condí ções de deformação dūctil, predominando no final condições de recristalização sem esforços dirigidos. ZWART $(1963,1964)$ mostra que numa mesma fase de metamorfismo podemos tex even tos de deformação e incremento de temperatura com máximos defasados no decorrer do tempo.

Em função da complexidade do problema, estes mode los não podem ser tomados como soluções definitivas. o que pode ser afirmado com certeza è que essas rochas foram submetidas a um processo de intensa deformação e microgranula ção dos grãos minerais. o qual pode ou não ser denominado. 
"cataclase", mas que não implica obrigatoriamente em proces sos rúptels sensu stricto. Foi seguido ou acompanhado de dobramento cerrado a isoclinal, transposição, metamorfismo de fácies anfibolito e migmatização. Restringiu-se a uma zona estreita e planar, subvertical, denominada em escala re gionàl como Lineamento de Alëm Paraỉba. As texturas isótro pas originais das rochas de fácies granulito foram poupadas apenas em "boudins" e inclusões tectônicas preservadas da de formação.

As relações de campo; como observadas na

Zona Principal de Deformação, mostram que a migmatização ocorreu simultaneamente à transposição intensa. Não foram encontra das evidências seguras de outras fases de migmatização.

Posteriormente, a foliação marcante dessas rochas é cortada por planos de crenulação discordantes.

Existem evidências de que movimentos posteriores tipo transcorrentes afetaram todas estas estruturas. Estas evidências são representadas pelas faixas de blastomilonitos mais finos (tipo "a"), sem o padrão de dobramento e transpo sição anteriores, com biotitas e quartzo planar deformados, englobando eventualmente "boudins" das rochas blastomilonitti cas anteriores, com foliações discordantes. Nota-se ainda que estas faixas estão frequentemente associadas com padrões mais densos de lineações. Ocorrem principalmente numa faixa mapeada a beira do rio paraíba do Sul à montante de Três Rios. Mas ocorrem tambëm em faixas decimétricas a mētricas, não mapeäveis na escala adotada, separando corpos litológicos distintos e associadas a lineamentos morfológicos, carac terizados por longas depressões retilíneas. Tudo isso suge re que se tratam de faixas nas quais se concentraram os movi mentos de carāter transcorrente posteriores. Uma outra ex plicação alternativa seria a de que estas faixas não repre sentam movimentos posteriores aos que originaram o restante das rochas blastomiloniticas, mas sim faixas com maior taxa (velocidade) de deformação com o tempo, o que poderia também 
explicar as felções observadas. No entanto, algumas evidên clas, como os "boudins" de rochas blastomiloniticas mais tI picas englobadas dentro dessas faixas, parecem mais difí ceis de explicar-se dessa maneira.

As falhas transcorrentes menores com direções em torno de $\mathrm{N}-\mathrm{S}$ podem ser explicadas como sendo falhas conjuga das desse último falhamento transcorrente principal de dire ção NE.

A formação dos corpos de pegmatitos mostra-se re corrente sobre um certo período de tempo em relação aos últi mos eventos de transcorrência. Isto pelo fato de observar-se pegmatitos intrudidos nos planos de falhas com direção em torno de $\mathrm{N}-\mathrm{S}$, apresentando graus de deformação varıáveis, assim como pelo fato de se encontrar diques de pegmatitos não deformados cortando obliquamente rochas blastomiloniticas.

Os diques de diabásto e lamprófiros provavelmente intrudiram-se aproveitando a zona de fraqueza crustal cons tituída pelo lineamento de Alēm Paraíba. Pelas datações existentes na Região sudeste para este tipo de rochas, pode-se supor com razoāvel certeza que correspondem a fenômenos de idade Mesozóica, 'no período de reativação da Plataforma Sul-Americana. Por outro lado, evidências geomorfológicas relacionadas aos diferentes niveis de terraços na zona Principal de Deformação sugerem a ocorrência de movimentos verti cais. Pode-se supor com razoável grau de certeza que seriam devidos a falhamentos normais, ocorridos durante o Cenozói co, relacionados tambëm a reativação meso-cenozóica da Pla taforma sul-Americana, aproveitando-se das direções estrutu్ rais e da zona de fraqueza do Lineamento de Além Paraíba. No campo, não foram encontradas evidências de tal fenômeno. Co mo no entanto, os falhamentos normals podem ocorrer atë ao longo de simples planos, sem deformação apreciável das ro chas, a não observação destes no campo não invalida as evi dências de carāter geomorfológico. 
ser traçado:

a) formação de rochas em fácies granulito, de acox do com as paragêneses minerais que compõem os porfiroclastos das rochas blastomiloniticas, e de rochas granuliticas obser vadas como inclusões tectôntcas.

b) Dobramento recumbente nos blocos adjacentes à zo na de falhamento. Pelo menos em parte, as rochas dos blocos adjacentes formaram-se posteriormente aos granulitos.

c) Cataclase intensa em nivel crustal inferior. Foi acompanhada ou seguida de metamorfismo em fäcles anfibolito alta (conforme evidenciado pela matriz recristalizada das ro chas blastomiloniticas e a paragênese da maioria das rochas dos blocos adjacentes), dobramento cerrado a isoclinal, trans posição e migmatização incipiente.

d) Crenulação da foliação dessas rochas.

e) Segunda cataclase, relacionada claramente a movi mentos transcorrentes, a qual possivelmente se deu em nível crustal pouco mais alto do que a primeira.

f) Falhamentos transcorrentes menores com direção em torno de $\mathrm{N}-\mathrm{S}$, que provavelmente acompanharam ou seguiram a segunda cataclase. Intrusão de pegmatitos por esses planos de falha.

g) Intrusão dos últimos diques de pegmatitos.

h) Intrusões de diabásios e lamprōfiros.

i) Movimentos verticais ao longo de falhas normais, produzindo as feições morfolögicas observadas.

Este esquema foi elaborado na forma mais simples pos sivel. Deve-se ressaltar que as fases de cataclase podem ser recorrentes em várias épocas, podendo atē mesmo ocorrer movimentos modernos da zona de falha, complicando bastante a interpretação e invalidando esquemas simplificados. 


\section{8 - Anălise dos Dados Geocronolögicos Existentes}

A região em questão foi objeto anteriormente de es tudos geocronológicos cujos resultados e interpretações fo ram publicados por DELHAL et al. (1969) e CORDANI et al. (1971). Esses trabalhos tiveram um cunho regional, abrangendo uma grande área. Basearam-se em levantamentos geológicos ante riores, de escala relativamente pequena (EBERT, 1956, 1957; ROSTER, 1957, 1965). Portanto, foram construidas apenas cur vas e isócronas de referência.

Os afloramentos e amostras coletadas pelos autores citados para anālises radiométricas, dentro da ārea aqui estú dada em detalhe, estão plotados no mapa de pontos de aflora mentos (Anexo 2).

Os diagramas isocrônicos $\mathrm{Rb} / \mathrm{Sr}$ e as curvas concőr dias U/Pb mostraram tipicamente uma evolução policíclica, jã comentada no Capitulo 2.

Tendo acesso à suite petrográfica de J. DELHAL, uti lizada para as análises geocronológicas, foram redescritas as amostras coletadas dentro da ārea mapeada em detalhe (Folha de Três Rios), segundo os critērios de classificação esboça dos no Capítulo 1. Segue-se abaixo descrição sumária das se ções delgadas dessas amostras.

Afloramento $1 \mathrm{Am} \cdot 1$

Textura: granolepidoblástica fina.

Mineralogia: quartzo, biotita, microclíneo, musco vita (alteração de biotita).

Classificação: gnaisse fino.

Afloramento $1 \mathrm{Am} 3$

Textura: blastomilonitica grosseira. giocläsio.

Mineralogia: porfiroclastos de microclíneo e pla

Quartzo planar.

Matriz granolepidoblástica de microclíneo, quartzo, 
biotita, muscovita (secundāria).

Classificação: milonito-gnaisse tipo "b" (zonas de trànsição).

\section{Afloramento $2 \mathrm{Am} 4$}

Textura: bandada, com bandas composicionais bem de finidas, como se segue:

a) granolepidoblāstica grosseira, a quartzo (prin cipalmente), biotita, plagiocläsio, microclíneo (pouco), mus covita (secundāria).

b) Granolepidoblästica fina, a microclíneo (princi palmente), quartzo, biotita, plagiocläsio.

c) Granoblástica fina, a quartzo poiquiloblástico (principalmente), plagioclásio, biotita, microclineo.

d) Lepidoblástica a granolepidoblástica fina, a biotita (principalmente), hornblenda, quartzo, plagioclásio, piroxênio (?), apatita.

Classificação: gnaisse bandado.

\section{Afloramento 2 Am 5}

Textura: granolepidoblästica, com cataclase inci piente.

Mineralogia: quartzo, microclíneo, plagiocläsio, biotita.

Classificação: gnaisse.

Afloramento 2 Am 6

Textura: bandađa

a) granoblästica, bastante grosseira, a microcli neo, quartzo, plagioclásio, biotita.

b) granolepidoblástica média a fina, a plagioclą sio, quartzo, biotita.

Classificação: respectivamente neossoma e paleosso ma (gnäissico) de migmatito.

Afloramento $3 \mathrm{Am} 8$

Textura: blastomilonitica grosseira. 
Mineralogia: porfiroclastos de plagioclásio e per tita.

Quartzo planar.

Matriz fina, poligonizada, granolepidoblástica, de plagioclásio, quartzo (?), biotita, muscovita, clorita (secun däria), opacos.

Classificação: milonito-gnaisse tipo "a".

Afloramento 3 Am 9

Textura: blastomilonítica, matriz poligonizada do minante, com quartzo planar.

Mineralogia: porfiroclastos de plagiocläsio, perti ta. Matriz de plagiocläsio, quartzo (?), biotita, opacos,apa tita.

Classificação: blastomilonito tipo "b".

Afloramento $3 \mathrm{Am} 10$

Textura: blastomilonítica, fina a mêdia.

Mineralogia: porfiroclastos de plagiocläsio,hipers tênio.

Quartzo planar.

Matriz poligonizada, granolepidoblástica, de pla giocläsio, biotita.

Classificação: blastomilonito/milonito-gnaisse.

Afloramento $3 \mathrm{Am} 11$

Textura: blastomilonítica, bandada.

Mineralogia: porfiroclastos de hornblenda, plagio clāsio (raro).

Quartzo planar.

Matriz poligonizada de hornblenda, plagioclásio,

quartzo (?), feldspato potássico (?), biotita, apatita,opacos. Classificação: blastomilonito (băsico) tipo "b".

Afloramento 6 Am 16

Textura: granolepidoblástica fina a média, a pla gioclásio, quartzo, biotita, com estreita faixa cataclástica, a biotita (principalmente), quartzo, plagicolásio, carbonato. 
Classificação: gnaisse.

Afloramento $6 \quad \mathrm{Am} \quad 17$

Textura: granoblāstica, com grãos alongados e orien tados.

Mineralogia: microclíneo, plagiocläsio, quartzo,bio tita.

Classificação: gnaisse.

Afloramento $8 \mathrm{Am} 19$

Textura: granolepidoblästica a blastomilonítica. Mineralogia: quartzo planar, microclíneo, biotita, plagioclāsio, muscovita.

Classificação: gnaisse/blastomilonito.

Numa rediscussão preliminar desses dados radiomëtri cos, serão destacados apenas alguns aspectos principais. Lem: brando que o nümero de dados disponiveis na área da Folha de Três Rios, embora relativamente grande, não è suficiente para interpretações absolutamente seguras, e nem estes forma coletạ dos visando um estudo de detalhe.

o afloramento 3 situa-se dentro da zona Principal de Deformação, e as quatro amostras coletadas correspondem a rochas blastomiloníticas típicas. No diagrama isocrônico, as quatro amostras deste afloramento (nrs. 8, 9, 10, 11) alinharam-se com a isöcrona de $1.983 \pm 199 \mathrm{~m} . \mathrm{a} .$, R.I. $=0,7098$. No diagrama concōrdia $(\mathrm{U} / \mathrm{Pb})$ relativo a zircões, estas amostras cairam na corda que indica uma idade de $2.070 \pm 70 \mathrm{~m}$.a. para a formação dos zircões e de $600 \mathrm{~m}$.a. para um episōdio importante de perda de $\mathrm{Pb}$ radiogênico.

Interessante notar que a isōcrona transamazônica è definida por quatro pontos, relativos às amostras 121a, 121b (gnaisses a hiperstênio e granada da região de Carangola),8, 9, 10 e 11 (rochas blastomiloníticas da região de Três Rios). Cal culando-se separadamente as idades e razões iniciais pelo méto do isocrônico para as amostras 12la e 121b, obtém-se uma idade de $2.165 \mathrm{~m}$.a. e razão inicial de 0,7092 . Para as amostras 8 , 
9 , 10 e 11 obtém-se uma idade de $1.923 \mathrm{~m} . \mathrm{a}$. com razão inicial de 0,7115 . Esta diferença foi interpretada por CORDANI et al. (1971) como sendo devida a um rejuvenescimento destas úl timas amostras durante o Ciclo Brasiliano.

Sem düvida, as isōcronas relativas às rochas blas tomiloniticas não devem fornecer idade de eventos anteriores à sua primeira cataclase, mais intensa, pois esta alëm de des truir o agregado cristalino anterior e abrir o sistema, envol veria rochas de diferentes tipos e regiões e permitiria o acesso de fluidos. Assim sendo, é razoāvel supor que a cataclase inicial dos blastomilonitos não seja mais antiga que o Ciclo Transamazônico. Por outro lado, podem ser sugeridas in terpretações alternativas para o fato das rochas blastomiloní ticas fornecerem isócronas com idades um pouco mais baixas e razões iniciais mais altas, quando tratadas isoladamente. Por exemplo, poderiam ter ocorrido dois eventos no Transamazônico, um por volta de 2.160-2.070 m.a., correspondente ao metamor fismo de sedimentos do ciclo em questão ou de seu embasamento, e outro pox volta de $1.923 \pm 60 \mathrm{~m} . \mathrm{a}$. , relacionado à intensa ca taclase, dentro da zona do Lineamento de Alēm Paraíba. A ra zão inicial mais alta para as rochas blastomiloniticas indi caria que estas se formaram a partir do retrabalhamento de ma terial anterior. E a coincidência aproximada da idade obtida pela curva concōraia para zircões com a isócrona Rb/Sr que não leva em conta as rochas blastomiloníticas, fornecendo uma idade um pouco mais antiga, indicaria a época do metamorfismo do Ciclo Transamazônico. No entanto, os dados disponíveis não permitem optar por uma das interpretações possiveis.

As amostras do afloramento 2 (amostras $4,5,6$ ), no extremo sul da ärea mapeada, corresponden a migmatitos e gnaisses tỉpicos da Serra dos Ôrgãos. A separação dos paleos somas e neossomas das amostras 4 e 5 forneceu frações que cor respondem a dois dos cincos pontos que constituem a isócrona brasiliana $(566+122 \mathrm{~m} . \mathrm{a} ., \mathrm{R} . I=0,7087)$. No diagrama $\mathrm{U} / \mathrm{Pb}$, localizam-se na curva concórdia por volta do valor de 600 m.a. 
Estes dados indicam que tratamse de rochas formadas no Ciclo Brasiliano.

As amostras 16 e 17, do afloramento 6, situam-se dentro da Zona de Transição NW. Equivalem particularmente a gnaisses bandados com pouca ou nenhuma evidência de cataclase. No diagrama isocrônico localizaram-se entre as isócronas bra siljana e transamazônica, bastante próximos destà 'ültima.

A amostra 3 (afloramento 1) situa-se na zona de Transição SE. E um milonito-gnaisse típico das zonas de tran sição. A amostra 19 (afloramento 8) é de um gnaisse do Bloco SE da Zona de Alëm Paraíba, porém apresentando em parte textú ra blastomilonitica. Ambas amostras corresponderiam a pontos que se situam entre as isócronas transamazônica e brasiliana, mais próximos desta última.

Estes casos de pontos situados entre as duas isó cronas provavelmente referem-se a rochas formadas no Transa mazônico e parcialmente afetadas pela redistribuição do $\mathrm{Sr}$ radiogênio do Ciclo Brasiliano.

Isócronas minerais das rochas blastomiloníticas (amostras $8,9,10,11$ ) e de rochas das zonas de transição (amostras 16, 17, 19) forneceram idades brasilianas. Assim como as idades convencionais $\mathrm{Rb} / \mathrm{Sr}$ e idades $\mathrm{K} / \mathrm{Ar}$ para bioti tas e hornblendas de toda região. Isto indica a ocorrência de importante evento de recristalização durante o Ciclo Bra siliano.

Os ültimos eventos do Ciclo Brasiliano na região são representados por intrusões de pegmatitos (470 a 500 m.a.). o único dado radiométrico inédito aqui apresentado refere-se a datação pelo método $\mathrm{K} / \mathrm{Ar}$ de biotitas de um dique de pegmati to que corta obliquamente a Zona de Rochas Blastomiloniticas (Fotos 21 e 22). A análise foi realizada no Centro de Pesqui sas Geocronológicas do Instituto de Geociências da U.S.P. e forneceu os seguintes resultados: 
$\mathrm{K}(8) \quad \mathrm{Ar}^{40} \mathrm{rad} .\left(10^{-6} \mathrm{CC} \mathrm{STP} / \mathrm{g}\right) \quad$ Ar atm. (o) Idade (m.a.)
6,5054
145,0
3,52
$499 \pm 18$

Este dado fornece uma Idade minima para as rochas blastomiloníticas de $499 \pm 18 \mathrm{~m} . \mathrm{a}$. e sugere que os últimos mo vimentos transcorrentes também tenham essa idade minima.

Dado interessante de ser notado è que ao Norte do Lineamento de Alēm Paraíba, praticamente todas as amostras tratadas pelo mëtodo isocrônico cairam em isócronas transama zônicas ou mais antigas, sendo que apenas duas amostras (1.39 e 12lc) cairam em posição intermediăria entre a isócrona transamazônica e a brasiliana. Do mesmo modo, ao sul da zo na do Lineamento de Alēm Paraíba não se encontram amostras que se situam acima da isöcrona brasiliana. Estes dados su gerem que o Lineamento de Além Paraíba separa blocos com dí ferentes padrões radiomëtricos. 


\section{4 - INTEGRAÇAO REGIONAL E EVOLUÇÃO GEOLOGICA}

Observando-se o mapa de lineamentos obtidos a par tir de imagens MSS do satélite Landsat-1 (Anexo 4), nota-se uma configuração de āreas com diferentes padrões de linea mentos. Esse mapa foi construído levando-se em conta prin cipalmente os lineamentos menores mais finos, que correspon dem em sua maior parte à foliação metamórfica das rochas. As āreas com diferentes padrões observados correspondem por tanto a āreas com diferentes padrões e/ou atitudes de folia ção. Nota-se ainda que áreas mais extensas com diferentes padrões são limitadas, por vezes de modo brusco, por faixas mais estreitas, fortemente foliadas e com atitudes discor dantes. Estas faixas estreitas fortemente foliadas e dis cordantes, correspondem possivelmente a grandes zonas de fa lhamentos, que delimitam blocos crustais de constituição di versa, evidenciada pelos seus diferentes padrões de linea mentos.

Algumas dessas zonas de falhamento foram mapeadas e ganharam nomes, tais como as de Guiricema, Guaçui, Rio Pre to, Barra Mansa (BRANDALISE et al., 1976) e São João do Pa raiso (CostA et al., 1978). A maior delas no entanto, cor responde ao Lineamento de Alëm Paraíba (Falha do Paraíba do Sul Médio-Inferior, de BRANDALISE et al., 1976). Este acha- se mapeado e bem definido entre localidades de Volta Redon da (RJ) e Itaocara (RJ), correspondendo a uma faixa de até $10 \mathrm{~km}$ de rochas fortemente deformadas, como mostrado neste trabalho e em publicações anteriores (ALMEIDA et al,,1975; BRANDALISE et al.,1976; FERRARI et al,,1977, VASCONCELOS \& MIRANDA, 1978). Constituí-se no eixo principal deste siste ma de falhamento, visto que as demais zonas de falhamentos apresentam amplas inflexões nas suas direções, passando de aproximadamente $\mathrm{N} / \mathrm{S}$ para ENE conforme aproxima-se assintoti camente da zona do Lineamento de Além Paraíba.

A continuidade do Lineamento de Alēm Paraỉba tan to para $\mathrm{NE}$ como para $\mathrm{SW}$, não estā rigorosamente definida. 
Para NE, sua continuidade mais definida ē o relativamente es treito Lineamento de são João do Paraiso (CoSTA et al., 1978a, b), que trunca as direções estruturais dos seus blocos ađjacentes. Porëm, nas āreas mapeadas por convênio com o D.R.M./ /RJ (op.cit.), predominam amplamente as rochas com texturas blastomiloniticas sobre aquelas com texturas granulares homo gêneas, numa extensa ärea, tornando-se difícil caracterizar a continuidade do Lineamento de Alëm Paraiba como uma faixa de rochas deformadas que corta rochas menos deformadas. Não parece claro, no entanto, se isto se deve realmente a uma maior extensão do processo de blastomllonitização nessa áreà, ou se é apenas uma feição aparente, devido a critērios de ma peamento adotados, que não teriam como base principal o grau de deformação das rochas. No entanto, nos mapas do : Projeto Espirito Santo da C.P.R.M. (SILVA \& FERRARI, 1976) nota-se que a partir do $\mathrm{NE}$ do Estado do Rio de Janeiro ocorre um sis tema de falhas transcorrentes com direções ENE, sendo que no norte do qual ocorre outro sistema com traços curvilineos, que infletem de ENE para $\mathrm{N} / \mathrm{S}$, da mesma maneira que na região do Lineamento de Alëm Paraỉba. O sistema com direção ENE esten de-se ao interior do Estado do Espirito Santo, desaparecendo sob os sedimentos da Formação Barreiras e o Oceano Atínâtico, na altura da cidade de Guarapari: No rumo sw o Lineamento: de Alēm Paraíba encontra-se definido até encontrar a Via Du tra (BR-116), entre as localidades de Volta Redonda e Ptraí (ver BRANDALISE et al., 1976 e FERRARI et al., 1976). HASUI et al. (1977 a, b) sugerem que a continuidade deste para SW, sejam os falhamentos de Taxaquara e Cubatão, o que implica ria que esta estrutura adentra os Estados de são Paulo e Pa ranä, desaparecendo sob a Bacia do Paraná. No entanto, na ārea de interligação (Serra da Bocaina, SP), os mapeamentos existentes não oferecem o necessário detalhe. portanto a ex tensão conhecida no momento com certeza ë de $240 \mathrm{~km}$, e a ex tensão total presumida, considerando seus prováveis prolonga mentos, de mais de $1.000 \mathrm{~km}$.

Observando-se os trabalhos de EBERT (1968) e ROSIER 
(1965) percebe-se que muitas das unidades geológicas defini das por estes autores são pelo menos parcialmente limitadas pelos grandes lineamentos. Por exemplo: os Grupos Barbace na e Juiz de Fora (EBERT, 1967, 1968), ou Associação Barbą cena (SILVA et al., 1978), são separados de uma faixa chạ noquitica a $E$ pelo falhamento de Guiricema. ROSIER (1965) mostra que algumas das unidades por ele mapeadas apresentam em alguns pontos contatos por "faixas laminadas", como en tre a "Sērie Serra dos Orgãos" e a "Faixa Desengano", e en tre a "Faixa Eugenöpolis" e a "Série Paraỉba-Desengano". Es tas feições são tidas por esse autor como possiveis acavala mentos. As faixas charnoquíticas observadas no mapa de ROSIER (1965) apresentam tambēm razoāvel coincidência com alguns "blocos" delineados no mapa de lineamentos (Anexo 4). Estas evidências sugerem fortemente uma estruturação crus tal em blocos de falha para a ārea. No entanto, apesar dá região jā estar mapeada totalmente nas escalas 1:500.000 e 1:250.000, e localmente em escalas maiores (ver Anexo 1), a diferenciação e delimitação das diversas unidades em geral não coincidem, em função provavelmente de métodos e critẹ rios de mapeamento distintos em cada caso. Torna-se então muito difícil a apresentação de um mapa geológico integra do da região, o que poderia comprovar esta estruturação em blocos.

o Lineamento de Além Paraíba caracteriza-se em to da sua extensão por uma faixa de rochas intensamente defor madas, com texturas blastomiloniticas predominantes, ondeas feições mais conspỉcuas são uma foliação vertical a sub vertical e lineação subhorizontal extremamente intensas.Ban damento composicional conspícuo è tambëm observado em todá sua extensão, assim como intensa "boudinage" de rochas tais como anfibolitos e calcossilicatadas. Dobras mesoscöpicas fechadas a isoclinais, de fluxo, com planos axiais verti cais, tambēm são observados em toda sua extensão, porém orá com eixos subhorizontais ora subverticais (ALMEIDA et al., 1975; BRANDALISE et al., 1976). 
Os únicos trabalhos de detalhe realizados anterior mente sobre as rochas blastomiloniticas, são os de CosTA et al. (1978 a, b, c), que abrangem uma ārea mapeada na escala 1:50.000 na continuidade do Lineamento de Além Paraíba a $\mathrm{NE}$ de Itacoara (ver Anexo 1). Como já dito, naquela ärea as ro chas com texturas blastomiloniticas predominam sobre as com texturas mais homogêneas. O esquema evolutivo proposto para essa ārea por costA et al. é bastante semelhante ao de Três Rios, aqui delineado. Sinteticamente, teriamse inicialmente a formação de charnoquitos e leptinitos, com texturas hipidio mörficas granulares, grosseiras, que teriam sido submetidas a um processo de metamorfismo, constituído de três fases. Na primeira teríamos a predominância de recristalização sobre a cataclase, dando origem a granulitos e gnaisses com texturas blastomiloniticas, assim como a foliação, lineação e dobras de cisalhamento. Numa segunda fase, umă recristalização ter mal, pós-tectônica, fornecendo as texturas granoblásticas, equligranulares, poligonais e finas. Na terceira, a catacla se predominando sobre a recristalização, formando cataclasi tos e milonitos. Vale apenas ressaltar as considerações fei tas no item 3.7 a respeito das relações temporais e genéti cas entre estas três "fases". O processo de poligonização, por exemplo, está basicamente condicionado por deformações no reticulo ocorridas na primeira fase, podendo ser a recrista lização sincrôntca ou posterior, sendo mais provavelmente sin crônica ou taraia em relação à primeira fase, pois nesta ocor reram condições energēticas suficientes para provocá-la. Tambëm notou-se que nos trabalhos de costA et al. muitas vezes considerou-se como texturas miloníticas, aquelas em que ocor ria predominância de grãos minerais maiores deformados (por firoclastos) em meio a matriz, e de texturas granuliticas aquelas mais finas, com raros porfiroclastos, quartzo "di. coidal" e matriz poligonizada fina. Na verdade, conforme já discutido no it.em 3.7, estas texturas tidas como "granuliti cas" são devidas basicamente a processos de deformação inten sa do reticulo cristalino dos grãos minerais, recuperação e 
recristalização, sendo então produtos de deformação extrema, e aquelas com texturas "miloníticas" com grânulos de porfiro clastos remanescentes, produtos de deformação pouco menos in tensa, que não teria sido suftciente para ativar a total ré cristalização do agregado original, preservando os grãos maio res, "prē-tectônicos". Assim sendo, muitas das texturas in terpretadas como originadas na terceira fase podem na verdá de ser produtos da primeira, apenas sendo, de modo inicial mente inopinado, resultado de menor deformação.

De qualquer maneira, a problemātica quanto a evolu ção das rochas blastomiloniticas da região de são Fidēlis é muito semelharte a de Três Rios, mostrando ser, com grande probabilidade, correlacionäveis. Apenas que na região de são Fidëlis, as rochas charnoquiticas jä ocorrem em grandes unidades, ao passo que na de Três Rios, estas ocorrem como pequenos enclaves tectônicos (conforme mostrado tambëm por ROSIER, 1965 e EBERT, 1968).

$\mathrm{Na}$ possivel continuidade dessa estrutura para $\mathrm{SW}$, em direção ao Estado de são Paulo, ou seja, nos falhamentos de Taxaquara e Cubatão, a recristalização das rochas deforma das, se ocorre, dā-se em fácies metamórfica mais baixa.ALMEI DA (1955) descreve recristalização de quartzo, sericita, epí doto, clinozoizita, carbonatos e biotita em rochas das fa lhas da Serra da Cantareira, ao Norte da cidade de Sao Paulo. HENNIES et $a l$. (1967) descrevem que ocorreu "regeneração de biotita e muscovita e recristalização de zoisita" em filoni tos do falhamento de Taxaquara e recristalização de quartzo em grau variāvel nas demais rochas cataclāsticas. SADOWSKI (1974), ALVES (1975), CARNEIRO (1977) e HASUI et al. (1978) descreveram blastomilonitos em värios falhamentos da região, mas com recristalização apenas de quartzo. HASUI \& SADOWSKI (1976) afirmam que somente o quartzo chegou a se recristali zar nas zonas de falhas em torno da região da cidade de são Paulo. Somente ALVES (1975) faz referências a dobras mesos cópicas nesse tipo de rochas, em blastomilonitos da falha de 
Taxaquara. Como o Lineamento de Alëm Paraíba no Estado do Rio de Janeiro corta rochas de făcies metamórfica mais alta e Idades mais antigas, e ele pröprio apresenta uma evolução polifāsica, com feições de deformação dūctil e recristaliza ção predominantes, a correlação entre os falhamentos des duas regiões encerra alguns problemas. Uma hipótese a ser testada é de que as estruturas sejam correlacionáveis geogra ficamente, mas apresentam-se atualmente expostos segmentos seus formados a diferentes niveis crustais, mais profundos no Estado do Rio de Janeiro e menos em são Paulo.

A origem das rochas charnoquíticas da região tem recebido interpretações diversas. BARBOSA (1960) e ROSIER (1965) sugeriram que se tratasse de rochas basalticas, cor respondentes a sequências ofloliticas do geossinclíneo de idade assintica, metamorfizadas nas suas regiões profundas. EBERT (1968), em função das texturas miloníticas muito co muns nos paracharnoquitos, propõe que estes tenham sido ori ginados em planos de falhas, por desidratação parcial provo cada pela milonitização nas fases iniciais do diastrofismo, podendo ser posteriormente remilonitizados, jā na fäcies an fibolito. Para os ortocharnoquitos (com distribuição homogê nea dos minerais e granulação grosseira), sugere uma origem por remobilização dos paracharnoquitos em profundidade.

As evidências levantadas neste trabalho no entanto mostram claramente que as rochas de fácies granulito, com texturas granulares, homogêneas, grosseiras, composição bāsi ca (charnoquitica) foram afetadas pelo intenso processo de blastomilonitização. Sendo que as rochas blastomiloníticas de Três Rios alinham-se com a isócrona transamazônica, é for çoso admitir que as rochas charnoquiticas sejam de idade pré-transamazônica, conclusão esta jă indicada por cosTA \& MARCHETO (1978). Por outro lado, CORDANI et al. (1973) apre sentaram uma isōcrona (op.cit., Figura 5, păg. 17) de rochas consideradas como "gnaisses Mantiqueira" (Formação Barbacena) ocorrentes ao Norte de Juiz de Fora. A isōcrona constituí- 
-se de cinco pontos, dos quais quatro correspondem a rochas com texturas de milonito-gnaisses, embora não tão bem desenvolvidas como na região de Três Rios. Fornece idade de 2780 $\pm 166 \mathrm{~m} . \mathrm{a}$. e R.I. de $0,7060 \pm 0,0016$, o que sugere a ocorrên cia de processos de blastomilonitızação no Ciclo Jequiē.

Pelo que se pode observar, não foram datadas ro chas de fácies granulito com texturas não blastomiloniticas na região, as quais deveriam fornecer a idade de formação dos charnoquitos. Os dados disponÍveis sugerem que a forma ção das rochas de fäcles granulito se deu no Arqueano, so frendo sucessivos retrabalhamentos no decorrer do Proterozói $c o$.

o posicionamento temporal do processo de intensa granulação (cataclase), dobramento e recristalização que deu origem às rochas blastomiloniticas ainda é incerto. Como já discutido no item 3.8, não deve ser mals antigo que o Transa mazônico $(2.090 \mathrm{m.a.})$. Não pode ser mais recente que os gra nitos pós-tectônicos do Brasiliano (540 $\pm 60 \mathrm{m.a.})$, supondo-se que o dique de granito encontrado nas proximidades de Três Rios seja correlacionāvel a estes. De qualquer modo, a idade de $500 \mathrm{~m} . \mathrm{a}$. fornecida pelo dique de pegmatito encontra do cortando as rochas blastomiloniticas estabelece uma idade minima irrevogävel.

Dentro desta faixa temporal, o mals provável ē que - processo de blastomilonitização seja de idade transamazôni ca, pelo alinhamento das rochas blastomiloniticas mais típi cas com a isöcrona dessa idade. Resta saber que efelto te ria a principal fase de metamorfismo e migmatização do Brasi liano sobre essas rochas, a $620 \mathrm{~m} . \mathrm{a}$.

Ao Sul do Lineamento de Além Paraíba ocorreu mig matização brasiliana, dentro da Folha de Três Rios. Não exis tem dados radiométricos de neossomas de rochas blastomiloni ticas para comprovar migmatização brasiliana nessas rochas. Com certeza o Ciclo Brasiliano provocou eventos termais for tes nessas rochas, evidenciados pelas idades aparentes K/Ar, 
convencionais $\mathrm{Rb} / \mathrm{Sr}$ e isōcronas minerais. Os ültimos movi mentos transcorrentes devem ter findado por volta de 500-450 m.a., conforme evidenciado pelas idades K/Ar em bioti tas de pegmatito, que se intrudem pelos planos de falhas menores obliquas ou mesmo cortam a Zona de Rochas Blastomi loniticas. Estes dados mostram que esta ŭltima fase de transcorrência ë correlacionāvel com os demais falhamentos da região $\mathrm{SE}$, os quais devem ter ocorrido entre o metamor fismo regional do Ciclo Brasiliano (mais de $710 \mathrm{m.a.)}$ até a estabilização da plataforma, a cerca de $450 \mathrm{~m} . \mathrm{a}$. (HENNIES et al., 1969, HASUI \& SADOWSKI, 1976).

Nas Folhas de são João do Paraiso e Italva (Cosra et $a$ l., $1978 \mathrm{a}, \mathrm{b})$ encontram-se as melhores evidências de movimentos transcorrentes posteriores que afetaram a região. - Lineamento de São João do Paraiso trunca e deflete as di reções estruturais da ãrea, inclusive dos "milonitos" da Unidade Monte Verde, indicando movimento transcorrente dex tral, relacionado à terceira fase do metamorfismo, definida por esses autores. São comuns também os dobramentos mesos cöpicos e macroscópicos com eixos verticais, com estilo de dobras de fluxo, por vezes revirados para $\mathrm{SE}$, afetando os rumos das lineações subhorizontais. Estes dobramentos fo ram interpretados como devidos a arrastos provocados pelos movimentos transcorrentes.

Um conjunto de evidências sugere que o Lineamento de Além Paraíba comportou-se como uma zona de fraqueza du rante a reativação mesozóica-cenozóica da Plataforma Brasí leira. RUELLAN (1944) mostrou que o vale do Rio Paraíba dó Sul corresponde a uma depressão de ângulo de falha, em rela Ção ao bloco soerguido e basculado da Serra dos orgãos. BRANDALISE et al. (1976) indicam uma faixa central de rele vo escalonado no Lineamento de Alëm Paraíba, além da ocoñ rência de diques de diabásio e de corpos de rochas alcalí nas, estas ültimas tambēm assınaladas por FERRARI et al. (1977). Na ärea de Três Rios, o relevo escalonado e a ocor. 
rência de diques de diabásios são claramente relacionados a Zona de Rochas Blastomiloniticas (ver Anexo 3), sendo tam bém encontrados terraços aluvionals mais altos que o nível atual do rio.

Os dados levantados por HABERLEHNER (1978) e HASUI \& PONÇANO (1978) mostram a ocorrência de vārios epicentros de eventos sísmicos ao longo do Lineamento de Além Paraíba, mostrando que este provavelmente se constitui ainda numa zo․ na de fraqueza, não totalmente inativa.

O modelo proposto por WATSON (1973) ....enquadramse muito bem com as características do Lineamento de Alëm. Pa raỉba. Essa autora basicamente propõe que os maciços granu liticos arqueanos originats, com rochas de fácies granulito com texturas granulares e isötropas, sofreram intenso retra balhamento proterozóico e fanerozólco, ao lóngo de lineamen tos profundos da crosta, sendo nestes totalmente reconsti tuidas. Nos blocos intermediários, delimitados pelos linea mentos, as estruturas do período de retrabalhamento sobre põem-se às anteriores. O retrabalhamento dentro dos linea mentos caracteriza-se pelo metamorfismo retrógrado das ró chas granuliticas para a făcles anfibolito alto, propiciado pela intensa deformação planar das rochas e reintrodução de āgua no sistema. o estilo de deformação, o padrão estrutú ral, textural e metamórfico, as 1dades radiométricas, e as relações com os blocos intermediários e o conjunto do siste ma de lineamentos, descritos por WATSON (1973) no seu mode 1o, são Idênticos àqueles do Lineamento de Alëm paraíba. 
Os dados levantados aqui e em trabalhos anteriores mostram que o Lineamento de Alëm Paraíba constitui-se num estreito cinturão de alta mobilidade da crosta, com largura de 9 a $10 \mathrm{~km}$ e extensão mapeada de $240 \mathrm{~km}$, podendo possivel mente alcançar mais de $1.000 \mathrm{~km}$. Na região em que é mapeadó, corta rochas de fácies anfibolito e granulito, tendo ele pró prio rochas com estruturas blastomiloniticas predominantes, re presentando uma reconstituição na făcies anfibolito de ro chas de fắcies granulito mais antigas. Representa o eixo principal de um sistema regional de lineamentos que aparenta promover uma estruturação da crosta em blocos tectônicos.

o evento principal de blastomilonitização é prova velmente de idade transamazônica, sendo que as rochas de făcies granulito com texturas isōtropas e composição bāsica (charnoquitos, enderbitos) são forçosamente prë-transamazôni cas, possivelmente arqueanas. Na área mapeada em detalhe(Fo lha de Três Rios), a evolução metamórfica, textural e estrú tural das rochas blastomiloniticas inclui uma série de pró cessos, com deformação intensa do retículo cristalino dos grãos originais (podendo ou não ser denominada de "catacla se"), recuperação ("recovery"), recristalização, retrometamor fismo da fắcies granulito para anfibolito alto, "boudinage" e estiramento, dobramento cerrado com planos axiais verti cais e eixos subhorizontais, transposição e migmatização in cipiente.

A homogeneidade estrutural é muito grande, com to dos elementos lineares e planares paralelos entre si. A re lação temporal entre esses processos não é clara, podendo mais provavelmente ser relacionados a um unico evento de in tenso achatamento dessas rochas, eventualmente com variação do estilo de deformação com o tempo, passando de francamente rūptil até extremamente dūctil, com recristalização termal 
ao final. No entanto a relação genētica ē clara, com uma deformação inicial do agregado e dos retículos cristalinos originais, ativanđo a recristalização e a ação da água, as quais por sua vez aumentaram incrivelmente a ductibilidade das rochas, podendo chegar à migmatização incipiente. Na ärea mapeada em detalhe, estes processos ocorrem com maior intensidade numa faixa central do Lineamento de Além Paraí ba, tornando-se menos intensos em zonas de transição e nos blocos adjacentes, onde o dobramento cerrado vertical e a transposição bem menos conspicuos, sobrepõe-se a pelo menos uma fase anterior de dobramento recumbente. As rochas dos blocos adjacentes pelo menos em parte, formaram-se poste riormente às rochas de fácies granulito.

Todos esses processos de retrabalhamento não são mais antigos que o Transamazônico, e não são mais novos que a Fase Principal de Deformação e metamorfismo do Ciclo Bra siliano, que poderia eventualmente corresponder à transposição, migmatização e crenulação das rochas blastomilonîti cas. No entanto, os dados disponiveis no momento não permí tem esclarecer a questão. Com certeza, pertencentes ao fí nal do Ciclo Brasiliano, temos eventos de movimentação trans corrente, que retalharam a zona de Rochas Blastomiloniticas em duas direções conjugadas (a principal paralela à folia ção das rochas), crenulação das foliações antertores, e in trusão de corpos de pegmatitos e granitos, alëm de fortes eventos termais.

Apōs o término do Ciclo Brasiliano, a evolução da faixa do Lineamento de Alēm Paraíba esteve ligada aos estā dios de estabilização e reativação da Plataforma Brasileira (ALMEIDA, 1969). A partir do Jurāssico, ocorreram intru sões de diabāsios e rochas alcalinas, alēm de movimentação vertical ao longo de planos de falhas, dando origem ao rele vo escalonado da Zona de Rochas Blastomiloniticas. Possi velmente, alguma atividade tectônica muito tênue estende-se atē os dias de hoje. 
Os padrões metamōrficos, estruturais e geocronolō gicos do IIneamento de Alēm Paraỉba são bastante coerentes com o modelo que WATSON (1973) propôs para o retrabalhamen to proterozóico e fanerozóico de maciços granulíticos de idade arqueana.

Diversos problemas encontram-se em aberto em rela ção a esssa estrutura. Datações radiomētricas de rochas dé făcles granulito, com texturas 1sōtropas indeformadas, de diversos tipos de rochas blastomiloniticas e de neossomas dessas rochas poderiam elucidar melhor as relações tempo. rais com os diferentes ciclos tectônicos que afetaram a re gião. Estudos de análise microtextural mais detalhados é anāilse quantitativa de petrofabric poderiam eventualmente esclarecer melhor as relações entre processos tais como "ca taclase", recristalização e dobramento. Estudos regionais de geofisica, principalmente aeromagnetometria e gravime tria, poderiam elucidar as relações crustais em profundidá de dessa estrutura. Estas questões seriam importantes para compreender a estruturação e evolução geológlca regional.

A importância prātica imediata do estudo dessa es trutura relaciona-se mais a seus eventos recentes, para obras de engenharia civil (presença de fraturas abertas, ocorrência de sismos) e mineração (depōsitos hidrotermais e magmāticos, e ocorrência de ãgua mineral, associados a sistemas densos de fraturas). 
6 - AGRADECIMENTOS

o autor deve agradecimentos a um grande número de pessoas, que direta ou indiretamente colaboraram para a rea lização desta Dissertação de Mestrado.

Em primeiro lugar ao Professor Doutor Fernando Flávio Marques de Almeida, que soube orientar com paciência e objetividade este trabalho, acompanhando-o em todas suas fases.

Aos Professores DoutorGeorg Robert Sadowski, Dou tor Yociteru Hasui, Doutor Rudolph Trouw e Doutor Rainer Schultz pela discussão e esclarecimento de algumas questões essenciais.

Aos colegas clāudio Riccomini, André Ferrari e Tomas Brenner, que colaboraram com o autor nos trabalhos de campo.

Ao Professor Doutor Marcos Aurélio Farias de oli veira pelo acesso à suite petrográfica de J. Delhal, além do auxílio e discussão de diversas questões.

Ao Professor Doutor Gilberto Amaral e aos colegas Chan Chiang Liu, Paulo Roberto Meneses, Waldir Paradella e Raimundo Almeida Filho pela cessão de imagens de satélite e discussão de aspectos da geologia regional.

Ao Professor Doutor Umberto G. Cordani pela execu Ção de anälise radiomëtrica no Centro de Pesquisas Geocrono lógicas da Universidade de são Paulo.

Ao Professor Doutor José Moacyr. Vianna Coutinho e colegas Eleno de Paula Rodrigues e Maria Cristina de Moraes pela descrição de seçä́o delgada.

Ao Professo: Doutor João Baptista Moreschi pela descuição de seçãu pclida.

Ao Professor Doutor Miguel Alves Lima pelo apolo dado ao autor, permitindo o acesso ao arquivo de fotos. 
aēreas e cartas topográficas do IBGE.

$\AA$ equipe da Seção de Laminação do Instituto de Geociências da Universidade de são Paulo, na pessoa da se nhora Melany Thereza Isauk, e ao Senhor Gilson Batista, pe la execução das seções delgadas.

Aos motoristas Senhor Durval José de oliveira e Senhor Antônio Ribas Peres que acompanharam o autor nos tra balhos de campo, assim como ao Chefe da Seção de Veículos do Instituto de Geociências da U.S.P., Senhor Cisco Kid Tenōrio.

A equipe da Seção de Ilustração Grãfica do Institú to de Geociências da U.S.P., na pessoa do Senhor Jaime Alves da Silva, pela impressão e montagem deste volume.

Ao fotográfo Senhor Jaime de Souza Marcos pelos trabalhos de laboratório fotogräfico.

A Senhora Nair de Campos Louzada pela paciente e cuidadosa datilografia deste texto.

A Senhorita Lícia Haruyo Nagao, por todos os prés timos na preparação final deste volume.

Aos Senhor Wilson Leão, Senhor Vinícios Couto e Senhora Maria Elizete Campolim Fogaça pela confecção dos desenhos.

Ao Instituto de Geociências da U.S.P. pela acolhi da do autor como aluno de pós-graduação, e fornecimento da infra-estrutura para realização deste trabalho.

A Fundação de Amparo à Pesquisa do Estado de são Paulo (FAPESP) pela concessão de bolsa de estudos para o au tor e auxilio financeiro para os trabalhos de campo.

Ao Departamento de Recursos Minerais do Estado do Rio de Janeiro pelo apoio oferecido para a execução deste trabalho.

Ao Centro de Geologia Eschwege, nas pessoas dos Professores Everaldo Gonçalves e Celso Campolim Fogaga, e ao Instituto de Geociências da Universidade Federal de Minas 
Gerais, nas pessoas do Professor Wolney Lobato, e da Profes sora Yoco Katoo pelo apolo na elaboração final desta Disser tação.

A todos colegas, amigos e professores que auxilia ram o autor, discutindo aspectos por vezes essenclais, cola borando em tarefas rotineiras e fornecendo incentivo de or dem pessoal. 


\section{7 - REFERENCIAS BIBLIOGRÄFICAS}

AB'SABER, A.N. \& BERNARDES, N. - 1956 - Vale do Paraíba.ser ra da Mantiqueira e arredores de são Paulo. Rev.Eng.Min. Met. 24 (143): 284-292, Rio de Janeiro.

ALGARTE, J.P.; CUNHA, H.C.S.; DAITX, E.C.; CHIEREGATI, L.A. \& CAVALCANTI, J.C. - 1974 - Geologia da Folha de São Pau lo (Parcial). Anais XXVIII Congr.Bras.Geol., 1 : 339-337, Porto Alegre.

ALMEIDA, F.F.M. de - 1953 - Considerações sobre a geomorfogênese da Serra do Cubatão. Bol.Paul.Beogx., 15: 3-17, São Paulo.

ALMEIDA, F.F.M. de - 1955 - As camadas de são Paulo e a tec tônica da Serra da Cantareira. Soc.Bras.Geol., Bol. 4

(2) : 23-40, São Paulo.

ALMEIDA, F.F.M. de - 1964 - Fundamentos geológicos do relevo paulista. In Geologia do Estado de são Paulo, Bol. IGG

(41) : 167-263, são Paulo.

ALMEIDA, F.F.M. de - 1969 - Diferenclação Tectônica da Platạ forma Brasileira. Anais XXIII Congr.Bras.Geol., 1: 29-46, Salvador.

ALMEIDA, F.F.M. de - 1976 - The system of continental rifts bordering the Santos Basin. Intern.Symp. on Cont. Margias of Atlantic Type. An.Acad.Bras.Ciênc., 48 (Supl.) : 15-26, Rio de Janeiro.

ALMEIDA, F.F.M. de; HASUI, Y. \& CARNEIRO, C.D.R. - 1975 -

Lineamento de Alëm Paraíba. An.Acad.Bras.Ciênc., 47 (3/4): 575, Rio de Janeiro.

ALMEIDA, F.F.M. de; HASUI, Y. \& BRITO NEVES, B.B. de - 1976 The Upper Precambrian of South America. Bol. TG,Inst.Geoc., USP, 7: 45-80, são Paulo.

ALVES, F.R. - 1975 - Contribuição à geologia da região de Salesōpolis-Guararema, são Paulo: Inst.Geoc.,USP, Dissert. Mestrado, 136 p., São Paulo (inēdito).

ANTHONIOZ, P.M. - 1971 - Les Mylonites profondes, étude qualitative et comparative du métamorphisme blastomylonitique. . 
Sciences de la Terre, 16(2): 195-227, Nancy.

BACKHEUSER, E. - 1926 - Breve notícia sobre a geologia do Distrito Federal, Estatistica da Cidade. An. 1923-1924, V (18): 19-31, Rio de Janeiro.

BELL, T.H. \& ETHERIDGE, M.A. - 1973 - Microstructure of mylonites and their descriptive terminology. Lithos (6): 337-348.

BELOUSSOV, V.V. - 1962 - Basic problems in geotectonics. McGraw-Hill, 809 pp., New York.

BJÖRNBERG, A.J.S.; GANDOLFI, N. \& PARAGUASSU, A.B. - 1965 Novas observações sobre a tectônica moderna do leste de São Paulo. Rev.Eng.Min.Met., 11 (224): 137-140, Rio de Janeiro.

BRANDALISE, L.A. et alii - 1976 - Projeto Vale do Paraíba do Sul, Relatório Final. Conv.Dep.Nac.Prod.Min./Comp. Pesq.Rec.Min., 411 pp., Rio de Janeiro (inédito).

BRANNER, J.C. - 1919 - Resumo da geologia do Brasil para acompanhar o mapa geolögico do Brasil. Press of Judd e Detweiler Inc., Washington.

BRAUN, O.P.G. - 1972 - As faixas rúpteis do Brasil. XXVII Congr.Bras.Geol. (mimeografado).

CARNEIRO, C.D.R. - 1977 - Geologia e evolução geológica da Folha de São José dos Campos, SP. Inst.Geoc., USP, Dissert. Mestrado, $106 \mathrm{p}$. (inédito).

CHRISTIE, J.M. - 1960 - Mylonitic rocks of the Moine Thrust zone in the Assynt Region, Nortwest Scotland. Trans.Edin. Geol. Soc., 18: 79-93.

CHRISTIE, J.M. - 1963 - The Moine Thrust zone in the Assynt Region, Northwest Scotland. California Univ. Pubs. Geol. Sci., 40 (6): 345-419.

CORDANI, U.G.; DELHAL, J. \& LEDENT, D. - 1973 - Orogenèses supersëes dans le Precambrien du Brësil sud-oriental.Rev. Bras.Geoc. 3(1): 1-22, são Paulo. COSTA, L.A.M. da \& MARCHETTO, C.M.L. - 1978 - Evolução textural dos granulitos de são Fidëlis, RJ. An. XXX Congr. Bras.Geol., 3: 1250-1264, Recife. 
COSTA, L.A.M. da; GOMES, B.S.; BATISTA, J.J. \& MARCHETTO, C. M.L. - 1978a - Projeto Carta Geológlca do Estado do Rio de Janeiro, Relatórios Finals das Folhas São Fidélı, Cam buci, Italva e São João do Para1so. Dep.Rec.Min., Sec.Ind. Com.Tur.Est. Rło de Janeiro, Rio de Janeiro (inédıto). COSTA, L.A.M. da; GOMES, B.S.; BATISTA, J.J. \& MARCHETTO, c. M.L. - 1978b - Projeto Carta Geológica do Estado do Rio de Janeiro, Cartas Geológicas e Notas Explicativas das Fo lhas Cambuci, são Fidêlis, são João do Paraiso e Italva. Dep.Rec.Min., Sec.Ind.Com.Tur. Est. Rio de Janeiro, Rio de Janeiro.

COUTINHO, J.M.V. - 1953 - Petrologla da reg1ão de São Roque'; são Paulo. FFCL/UPS, Bol. (159), Młner. (11), 80 p., são Paulo.

COUTINHO, J.M.V. - 1972 - Petrologia do Prē-Cambriano em são Paulo e arredores. Bol. IG, Inst.Geoc., USP, 3: 5-99, São Paulo.

DALZIEL, I.W.D. \& BAILEY, S.W. - 1968-Deformed garnets in a mylonitic rock from the Grenville Front and their tectonic significance. Am.Jour.Sic., 266 (7): 542-562. DELHAL, J.; LEDENT, D. \& CORDANI, U.G. - 1969 - Ages $\mathrm{Pb} / \mathrm{U}$, $\mathrm{Sr} / \mathrm{Rb}$ et $\mathrm{Ar} / \mathrm{K}$ de formation metamorphiques et granitiques du sud-est du Brésil (ētats de Rlo de Janeiro et de Minas Gerais). Ann.Soc.Geol.Belgique, T.92, 1969, p. 271-283. DE SITTER, I.U. - 1956 - Structural Geology, MçGraw Hill Book Co.Inc. First edition, London. EBERT, H. - 1956 - Tectônica do Prë-Cambriano (São João del Re1). Depto.Nac.Prod.Min., Relatórlio anual do Diretor, ano 1956, p. 97-107, Rio de Janeiro. EBERT, H. - 1957 - Beltrag zur Gliederung des Prakambriums in Minas Gera1s. Geol.Rundschau, (215): 471-521. EBERT, H. - 1962 - Baustil und Reglonalithetamorphose im prakambrischen Grundgebirge Brasiliens. Tschermaks Miner. Petrogr. Mitt. 4 Folge, Bd. 8, H.1, pag. 49-81, Wien. EBERT, H. - 1967 - A estrutura prē-cambriana do Sudeste de Minas Gerais e ãreas adjacentes. Bol.Paran.Geoc., (26): 42-45, Curitiba. 
EBERT, H. - 1968 - Ocorrência de fácies granulítıca no Sul de Minas Gerais e em āreas adjacentes, em dependência da estrutura orogênica: hipótese sobre sua origem. An.Acad. Bras.Ciênc., 40 (Supl.): 215-229, Rio de Janeiro. EBBLIN, J.C. - 1974 - Cataclastic deformation. Geotectonics. ESCHWEGE, W.L.V. - 1832 - Beitrage zur Gebrigskinde

Brasiliens, $488 \mathrm{pp}$., Berlin.

FERRARI, A.L.; DUPUY, I.S.S. \& BRENNER, T.L. - 1977 - OCOrrência de rocha alcalina no município de Pirai, RJ, e sua relação com o Lineamento de Além Paraj́ba. An. Inst. Geoc., UnIv.Fed.Rio de Janeiro, ano 1977, pp. 114-121, Rio de Janeiro. FRANCO, R.R. - 1955 - Sobre um ultramilonito com estrutura fluidal. Bol.Soc.Bras.Geol., 4 (1): 43-48, são Paulo. FREITAS, R.O. de - 1944 - Geomorfogênese da Ilha de São Se bastião. Assoc.Geogr.Bras.,Bol (4): 16-30, são Paulo. FREITAS, R.O. de - 1947 - Geologia e petrologia da Ilha de são Sebastião.Fac.Fil.Ciênc.letr., USP, Bol. (85), Geol. (3) , pp. 1-245, São paulo. FREITAS, R.O. de - 1951a - Ensaio sobre o relevo tectônico do Brasil. Rev.Bras.Geogr., An. XIII (2): 171-222. FREITAS, R.O. de - 1951b - Relevos policíclicos na tectônica do Escudo Brasileiro. Bol.Paul.Geogr., (7): 3-19, são Paulo.

FRETTAS, R.O. de - 1956 - Considerações sobre a tectônica e a Geologia do Vale do Paraíba. Rev.Eng.Min.Met., 24 (143): 276-283, Rio de Janeiro. FREITAS, R.O. de - 1976 - Definição estrutural, petrológica e geotectônica das cintas orogênicas antigas do Litoral Norte do Estado de São Paulo. Bol.Inst.Geol.Est.são Paulo (1) : 1-176, São Paulo. GUIMARÃES, D. - 1960 - Fundamentos da petrologia e as rochas Ígneas do Brasil. Div.Fom.Prod.Min., Bol. 107, 410 p. Dep. Nac.Prod.Min., Rio de Janeiro. HABERLEHNER, H. - 1978 - Anālise sismotectônica do Brasil, notas explicativas sobre o Mapa Sismotectônico do Brasil 
e Regiões Correlacionadas. An. 28 Congr.Bras.Geol.Eng.,

1: 297-329. Assoc.Bras.Geol.Eng., São Paulo.

HASUI, Y. - 1973 - Tectônlca da ārea das Folhas de são Roque

e Pilar do Sul. Inst.Geoc., USP, Tese Livre-Docêncla,

190 pp., São Paulo (inēdito).

HASUI, Y.; PENALVA, F. \& HENNIES, W.T. - 1969 - Geologia do

Grupo são Roque. An.XXIII Congr.Bras.Geol., pp.101-134,

Salvador.

HASUI, Y.; CARNEIRO, C.D.R. \& COIMBRA, A.M. - 1975 - The

Ribeira Folded Belt. Rev.Bras.Geoc. $5(4): 257-266$, São

Paulo.

HASUI, Y. \& SADOWSKI, G.R. - 1976 - Evolução geolögıca do Prē-Cambriano na região Sudeste do Estado de são paulo. Rev.Bras.Geoc., 6 (3): 182-200, São Paulo.

HASUI, Y.; ALMEIDA, M.A. \& PONÇANO, W.L. - 1977 a - Comparti mentação geomorfológica do Planalto Atlântico do Leste de São Paulo. Soc.Bras.Geol., Núcleo SP, Atas 18 Simp. Geol. Reg., p. 153-169, São Paulo.

HASUI, Y.; PONÇANO, W.L.; BISTRICHI; C.A.; STEIN, D.P.; GALVÃO, C.A.C.F.; GIMENEZ, A.; ALMEIDA, M.A.; MELO, M. \& PIRES NETO,A.G. - 1977b - As grandes falhas do leste pau lista e sua importância. Soc.Bras.Geol., Nucl. SP. Atas 18 Simp.Geol. Reg., p. 369-380, São: Paulo. HASUI, Y. \& PONÇANO, W.L. - 1978 - Geossuturas e sismicidade no Brasil. An. 2o Congr.Bras.Geol.Eng., 1: 331-338. Assoc.Bras.Geol.Eng., são Paulo. HASUI, Y,; PONÇANO, W.L.; BISTRICHI, C.A.; STEIN, D.P.; GALVÃO, C.A.C.F.; GIMENEZ, A.F.; ALMEIDA, M.A. de; PIRES NETO, A.G.; MELO, M.S. de \& SANTOS M.do C.S.R. dos - 1978 - Geologia da Região Administrativa 3 (Vale do Paraíba) e parte da Região Administrativa 2 (Litoral) do Estado de São Paulo. Div.Min.Geol.Aplic., Monografias (1), 79 p., Inst.Pesq.Tecn.Est.S.Paulo, São Paulo. HENNIES, W.T.; HASUI, Y. \& PENALVA, F. - 1967 - o falhamento transcorrente de Taxaquara. An.XXI Congr.Bras.Geol., p. 159-168, Curitiba. 
HIGGINS, W.M. - 1971 - Cataclastic Rocks. U.S.Geol.survey Prof. Paper 687, Washington.

HOBBS, B.E.; MEANS, W.D. \& WILLIAMS, P.F. - 1976 - An outline of structural geology. John Wiley \& Sons Inc., New York.

KEGEL, W. - 1961 - Os Lineamentos na estrutura geológica do Nordeste. An.Acad.Bras.Ciênc., 33(3/4): 25-26, Rio de Ja neiro.

LAMEGO, A.R. - 1938 - O Massiço do Itatiaya e regiões circundantes. Bol.Serv.Geol.Min., (88): 1-93, Dep.Nac.Prod. Min., Rio de Janeiro.

LAMEGO, A.R. - 1946 - Anālise tectônica e morfolōgica do Sistema da Mantiqueira, Brasil. An. IT Congr.Panam. Eng. Min. Geol., 3: 247-326, Petrópolis.

LAPWORTH, C. - 1885 - The highland controversy in British geology; its cause, course and consequences. Nature 32 : 558-559.

LEONARDOS, O.H. - 1935 - Ocorrência de garnierita em Areal, Município do Parahyba do Sul, Estado do Rio de Janeiro. Serv.Fom.Prod.Min., (9): 161-168, Dep.Nac.Prod.Min., Rio de Janeiro.

LEONARDOS, O.H. - 1939 - Calcārio de Moura Brasil, Estado do Rio. Rev.Ens.Min.Met., 4 (19):5, Rio de Janeiro. PEIVE, A.V. - 1960 -Fractures and their role in the structure and development of the Earth's crust. Intern.Geol.Congr., Report of the twenty-first session, part XVIII, pp.280-288, Copenhagen.

RAMSAY, J.G. - 1967 - Folding and Fracturing of Rocks. McGraw Hill, 568 p., New York. RAMSAY, J.B. \& GRAHAM, R.H. - 1970 - Strain variation in shear belts. Can.Journ. Earth Sci. 7 (786): 787-813. REED, J.C. \& BRYANT, B. - 1964 - Evidence for strike-slip faulting along the Brevard zone in North Carolina. Geol. Soc.America Bull., 75 (12): 1177-1196. RIDEG, P. - 1974 - Geology and structure of a portion of the Serra do Mar in Eastern São Pạulo, Brazil. Ph.D. Thesis,. "state University of New York at Binghamton, 145 p. (inédito). 
RIO DE JANEIRO. SECRETARIA DA INDUSTRIA, COMERCIO E TURISMO. DEPARTAMENTO DE RECURSOS MINERAIS - 1978 - I Seminário sobre critérios de Mapeamento Geológico e Nomenclaturas de Unidades do Pré-Cambriano do Estado do Rio de Janeiro e Areas Limitrofes. Rev.Min.Met. 42 (400): 11-13, Rio de Janeiro.

ROSIER, F.R. - 1953 - Cronologie du Précambrien dans la région de la Serra dos Orgãos (Estado do Rio de Janeiro). Congrēs.Geol.Intern.Alger, 1952, Comp.Rendus, Sect. I, V. 1, p. 111-113, Alger.

ROSIER, G.F. - 1957 - A geologia da Serra do Mar, entre os Picos de Maria Comprida e do Desengano (Estado do Rio de Janeiro). DNPM/DGM, Bol. 166, Rio de Janeiro. ROSIER, G.F. - 1965 - Pesquisas geológicas na parte oriental do Estado do Rio de Janeiro e na parte vizinha do Estado de Minas Gerais. DNPM/DGM, Bol. 222, Rio de Janeiro. ROSIER, G.F. - 1967 - In SCORZA, E.P., Relatōrio Anual do Diretor, ano de 1962, p. 23-24, DGM/DNPM, Rio de Janeiro. RUELLAN, F. - 1944 - Evolução geomorfológica da baía da Gua nabara e regiões vizinhas. Rev.Bras.Geogr., ano VI (4): 445-509, Rio de Janeiro.

SADOWSKI, G.R. - 1974 - Tectônica da Serra do Cubatão, SP. Tese Doutor., Inst.Geoc., USP, 159 p., são Paulo (inédito). SILVA, J.N. da \& FERRARI, P.G. - 1976 - Projeto Espírlto San to, Relatório Final. Conv.Dep.Nac.Prod.Min./Comp.Pesq.Rec. Min., 408 p., Belo Horizonte (inédito). SILVA, J.N. da,; SEIXAS, S.R.M.; PIMENTEL; G. de B., \& COUTINHO, M.G. da N. - 1978 - Projeto Mantiqueira-Furnas, Relatörio Final. Conv.Dep.Nac.Prod.Min./Comp.Pesq. Rec. Min., 394 p., Belo Horizonte (inëdito). SPRY, A. - 1969 - Metamorphic textures. Pergamon Press, 350 p. TULIIS, J.; CHRISTIE, J.M. \& GRIGGS, D.T. - 1973 - Microstruc tures and preferred orientations of experimentally deformed quartzites. Geol.Soc.America Bull. 84: 315-330. TURNER, F.J. \& WEISS, L.E. - 1963 - Structural analysis of metamorphic tectonites. McGraw Hill, 545 p., New York. 
VASCONCELOS, V.R. de A. \& MIRANDA, F.P. de - 1978 - Reconhe cimento geológico ao longo do novo traçado da rodovia BR-040 no Estado do Rio de Janeiro, Trecho Três Rios. Dep.Geol. Untv.Fed.Rio de Janeiro, Relatōrio da discipli na Estāgto de Campo IV. Rio de Janeiro (Inëdito).

WASBURNE, C. - 1930 - Petroleum Geology of the são paulo State, Brazil. Comm.Geogr.Geol.Est.s.Paulo, Bol. (22): 282 p., São Paulo.

WATERS, A.C. \& CAMPBELI, C.O. - 1935 - Mylonites from the San Andreas fault zone. Am.J.Sci., 5th Ser., 29, pp. 473-503.

WATSON, J.V. - 1973 - Effects of reworking on hlgh-grade gneiss complexes. Phil.Trans.R. Soc.Lond., 273: 4.43-455, London.

WILLIAMS, H.; TURNER, F. \& GILBERT, C.M. - 1970 - Petrogra fia, uma introdução ao estudo das rochas em seções delgadas. Ed.Univ.s.Paulo e Ed.Polígono, 424 p.., são Paulo. WINKLER, H.G.F. - 1977 - Petrogênese das rochas metamörficas. Edgard Bldcher Ltda. e co-edições URGS, 258 p., são paulo. ZWART, H.J. - 1963 - Some examples of the relations between deformations and metamorphism from central pyrenees. Geol.Minjb., 42 : 143-154.

ZWART, H.J. - 1967 - The duality of orogentc belts. Geol. Minjb., 46: 283-309. 


$$
\begin{aligned}
& \text { FOTO } 1 \text { - Fotografia aérea - USAF - escala original i:60.000. } \\
& \text { zonas de Rochas Blastomiloniticas e porções contị } \\
& \text { guas dos blocos adjacentes. No canto NE a cidade } \\
& \text { de Três Rlos, e no lado } \mathrm{W} \text { a de Paraíba do Sul. No } \\
& \text { tar o contraste morfológico entre a zona Principal } \\
& \text { de Deformação, as zonas de transição e os blocos } \\
& \text { adjacentes, a persistência dos lineamentos morfolō } \\
& \text { gicos de direção NE, a ocorrêncta de lineamentos } \\
& \text { com direções em torno de N/S, e denso conjunto de } \\
& \text { fraturas de direção NW. }
\end{aligned}
$$




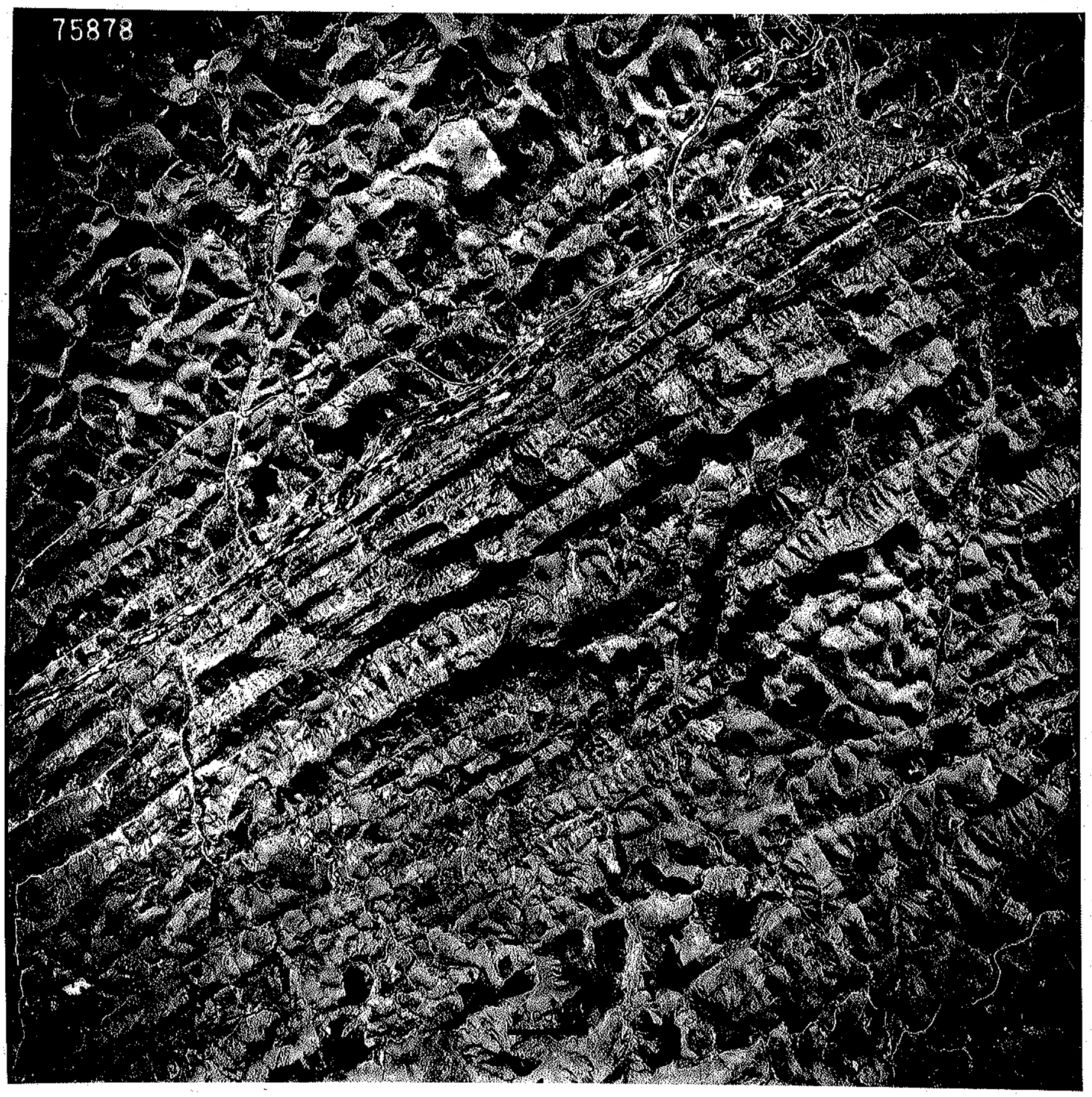

FOIO 1 
FOTO 2 - Milonito-gnaisse tipo "a". Notar a abundância, for ma e variação de tamanho dos porfiroclastos, assim como a forte variação lateral de texturas e granula ção.

FOTO 3 - Blastomilonito tipo "b". Notar a forte foliação, o bandamento composicional conspícuo, o aspecto gnäissico e a porcentagem baixa de porfiroclastos, em geral de tamanho pequeno.

FOTO 4 - Terraços aluvionares às margens do Rio Paraíba do Sul, mais altos que o nível deste.

FOTO 5 - Leito seco do Rio Paraiba do Sul, Zona Principal de Deformação. Notar a intensa foliação e a ocorrên cia de "boudin" de dimensões métricas na metade sü perior da foto.

FOTO 6 - Zona Principal de Deformação. Foliação intensa e bandamento composicional conspicuo dos blastomiloni tos tipo "b". (Corte vertical; Pedrelra Moura Brasil ou Tabaira.) 


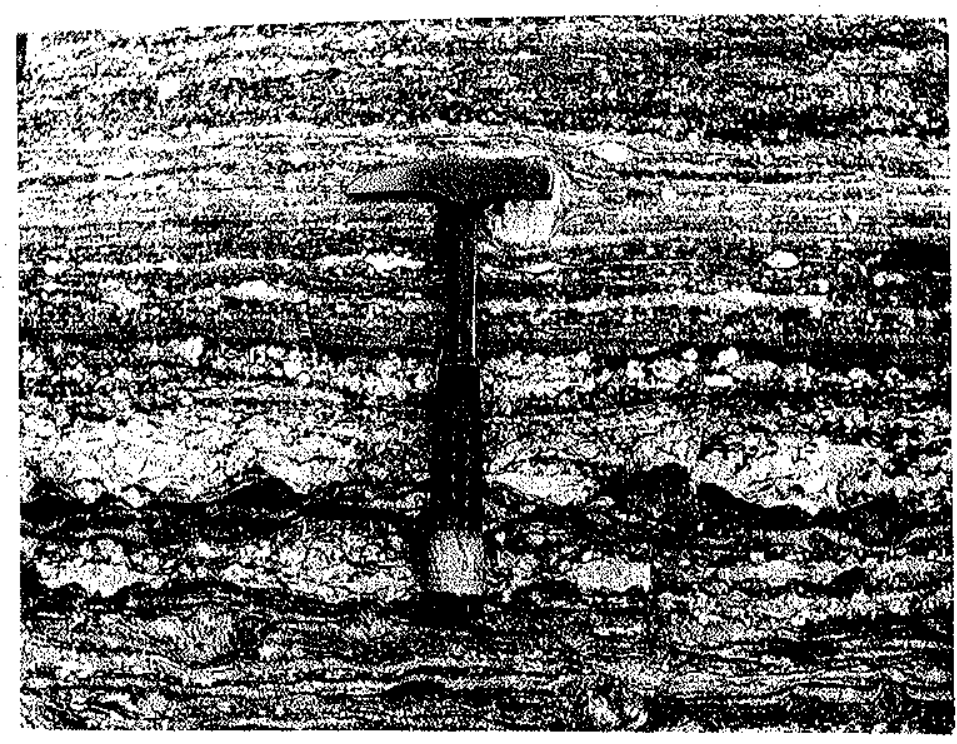

Foto 2

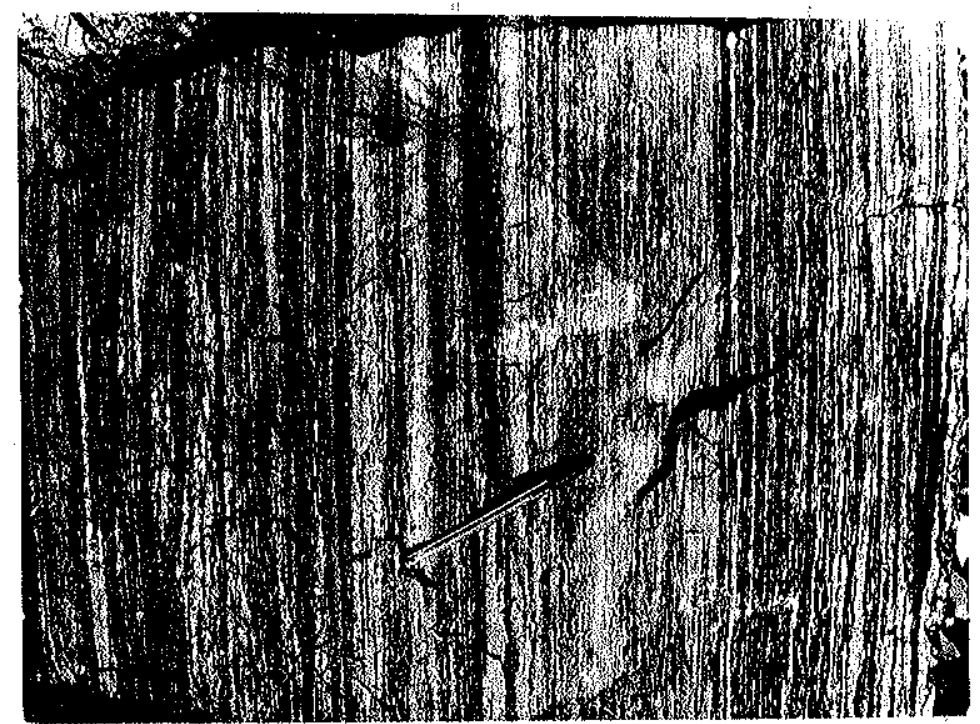

Foto 3

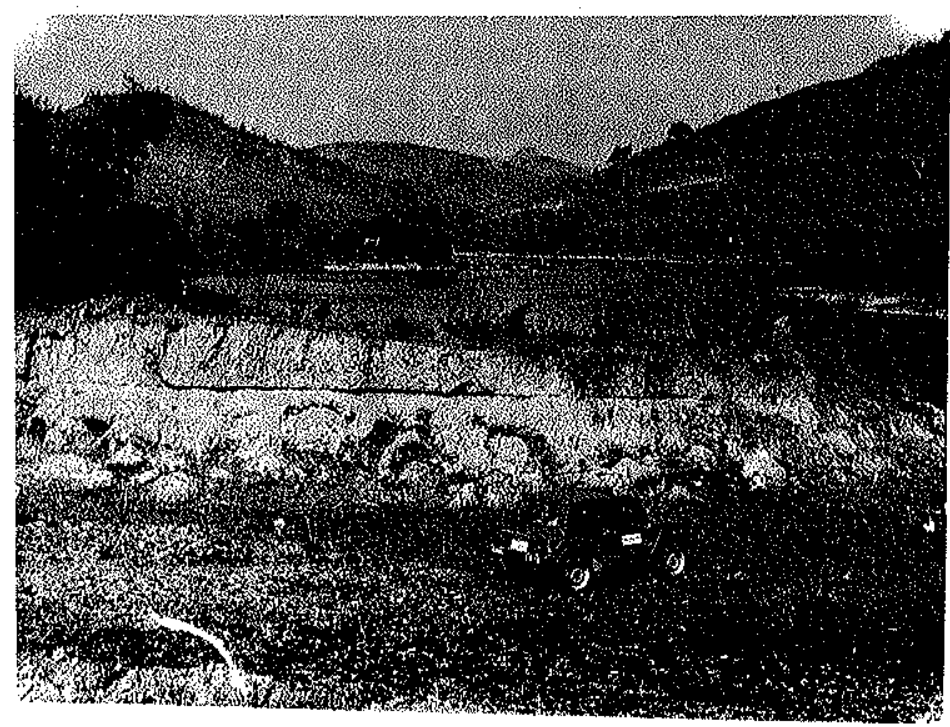

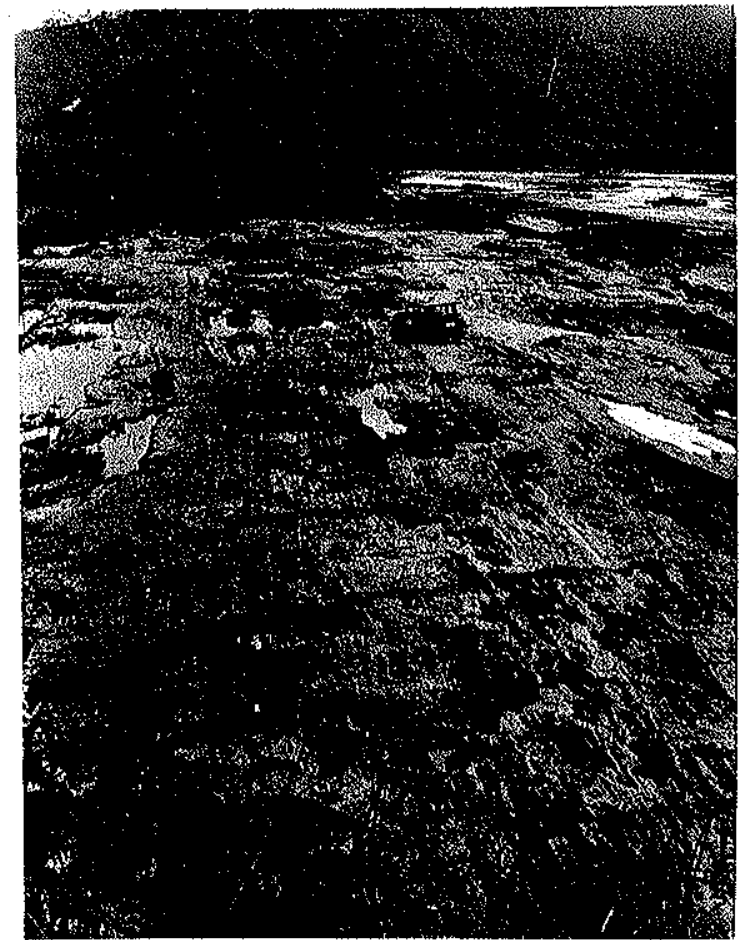

Foto 5

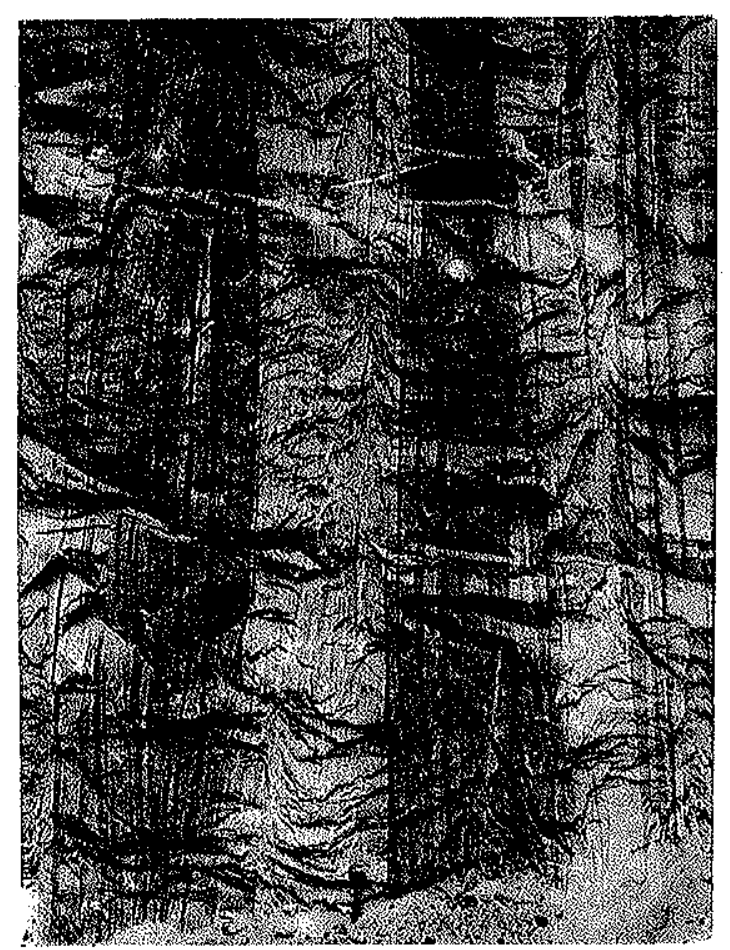

Foto

6 
FOTO 7 - Fotomicrografia. Nicóis cruzados. Porfiroclastos de mesopertita (?), em meio a matriz poligonizada de microclíneo, plagioclásio, quartzo, biotita e musoovita, apresentando agregados de grãos de quartzo com forma planar. Notar a forma elipsoidal do porfiroclasto, textura em moldura em suas bordas e a ocorrência de fai xas de matriz poligonizada mais fina, em meio a porções de grâ nulação maior.

FOTO 8 - Fotomicrografia. Nióóis cruzados. Porfiroclastos de plagioclásio, en meio a matriz poligonizada de plagioclásio, quartzo (?) e bio tita, com agregados de quartzo planar. Notar a extinção ondulante, geminações encurvadas, lamelas de deformação e forma elipsoi dal dos porfiroclastos de plagioclásio; os agregados de quartzo planar mostram-se em seção como "cordões" de quartzo, sendo cons tituídos por vários grãos, com ângulos de extinção diferentes $\bar{e}$ sem extinção ondulante; notar ainda a matriz com grãos poligonais, sendo que as bordas do porfiroclasto ao centro da foto encontram-se parcialmente poligonizadas.

FOIO 9 - Fotomicrografia. Nicóis cruzados. Detalhe da matriz poligonizada de blastomilonito. Notar a ausência de feições de deformação e a forma hexagonal de vãrios grãos da matriz, com pontos tríplices de contato em ângulos aproximadamente iguais. No centro da foto, um possivel porfiroclasto, quase que totalmente recristalizado e transformado num agregado de grãos poligonizados, sendo contorna do por agregados de quartzo planar.

FOTO 10- Fotomicrografia. Nicóis paralelos. Detalhe da matriz de milonito-gnaisse. Agregado recristalizado de sillimanita, biotita e quart zo. A biotita e sillimanita são na maior parte idiomörficas. Noentanto, alguns grãos maiores de sillimanita estão deformados, apresentando bordas irregulares, clivagens fraturadas e extinção
ondulante.

FOTO 11- Fotomicrografia. Nicóis paralelos. Rocha de fácles granulito,com textura granoblästica e deformação incipiente; com hornblenda, diopsídio, hiperstênio, plagioclásio, quartzo, apatita, opacos; os grãos maiores são arredondados, com extinção ondulante, sendo os interstícios estreitos entre eles preenchidos por matriz gra-
noblästica fina.

FOIO 12- Fotomicrografia. Nicóis paralelos. Blastomilonito "básico" tipo "b"; porfiroclastos de piroxênios, hornblenda, granada; matriz com texturas de equilibrio de quartzo e plagioclásio. 


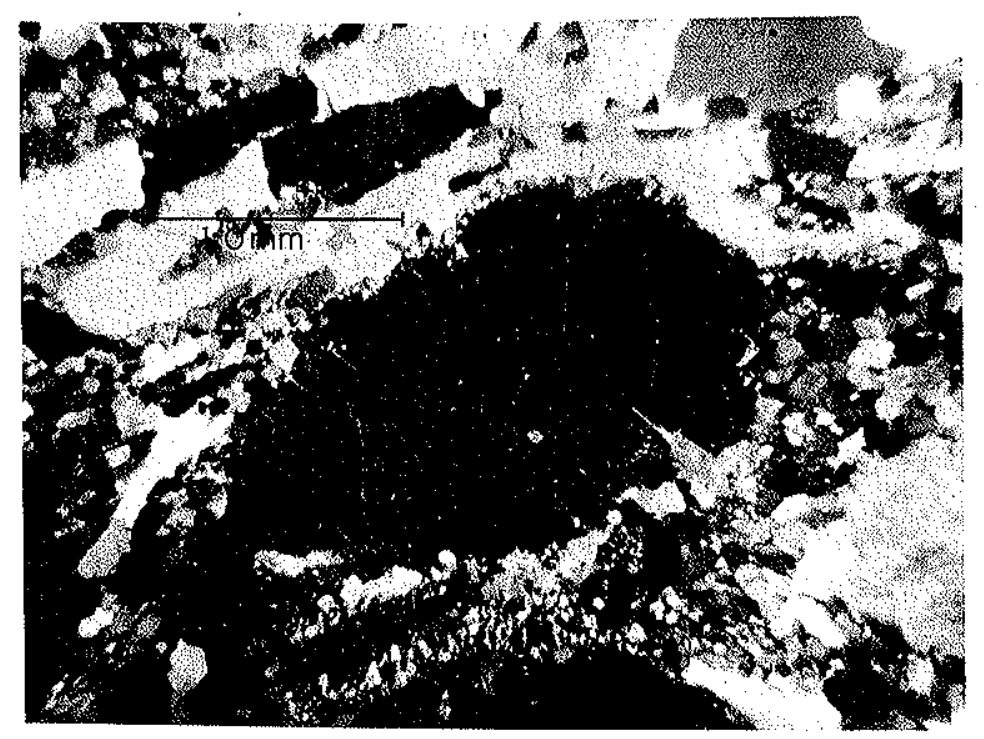

\section{Foto 7}

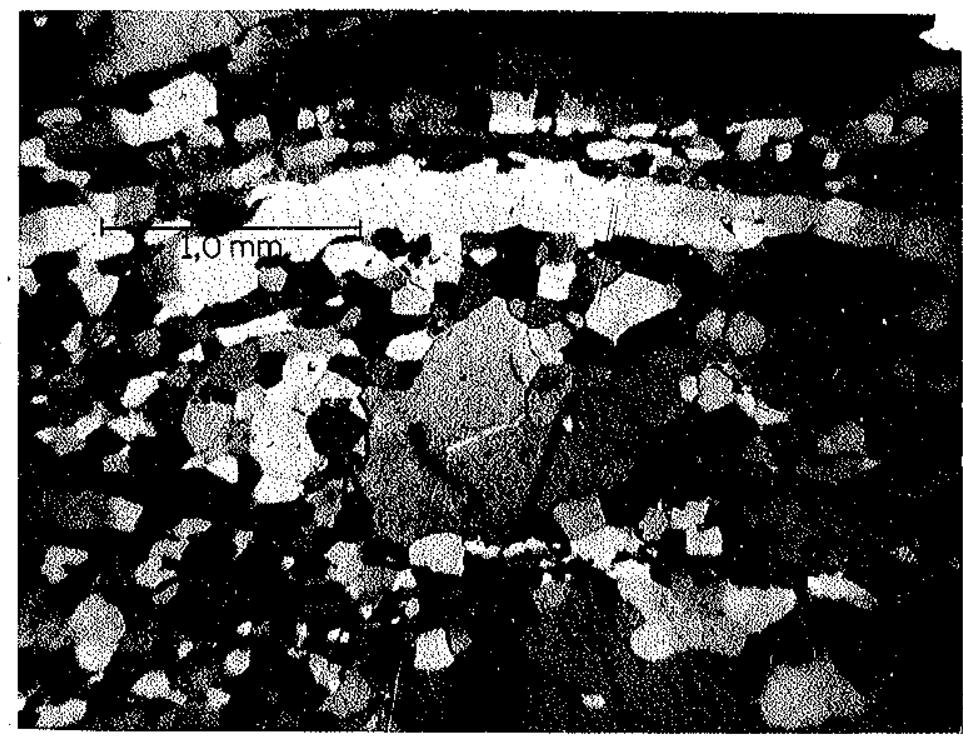

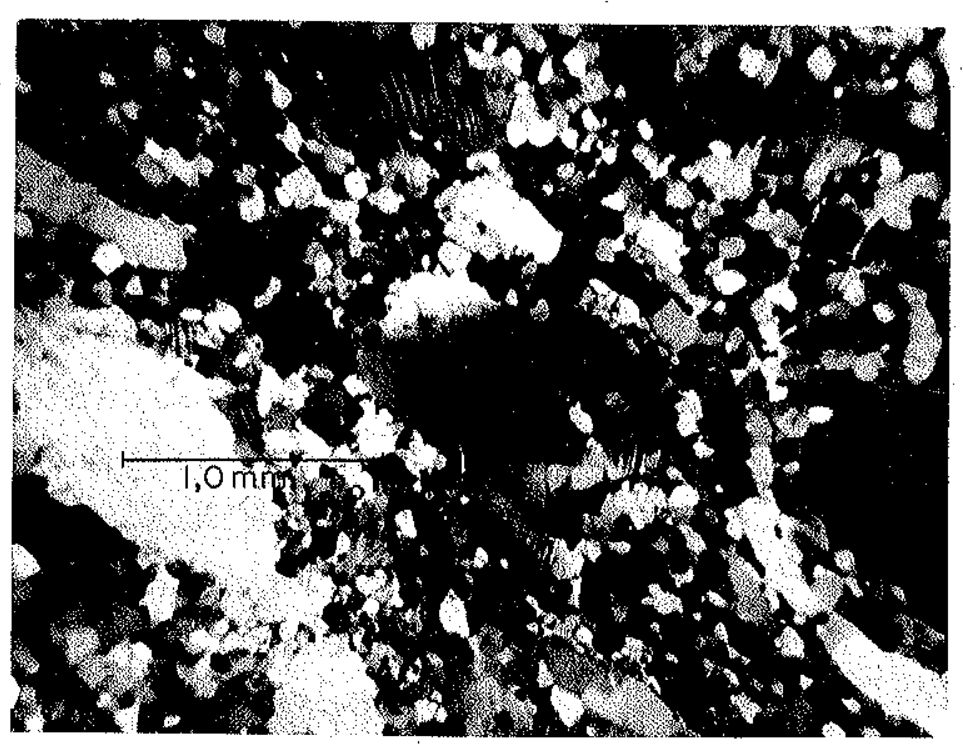

Foto 8

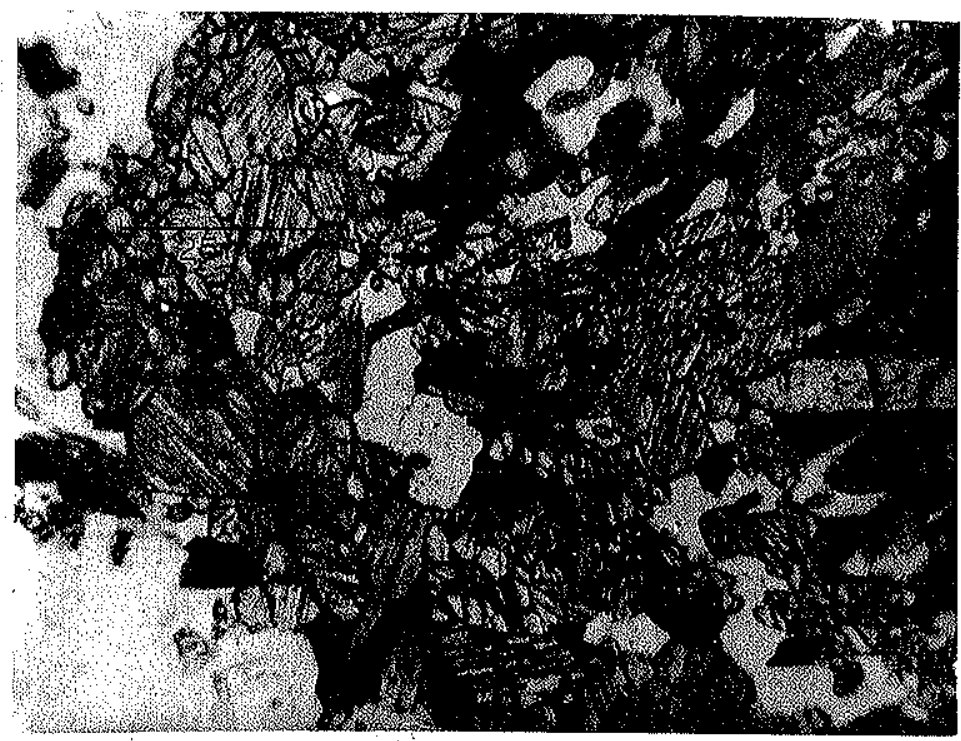

Foto 9

7.67\% 1. 2. 1.

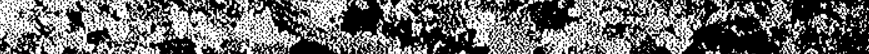
7.7. 1.6, 1. 16, F.

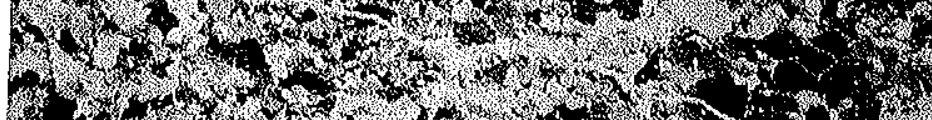

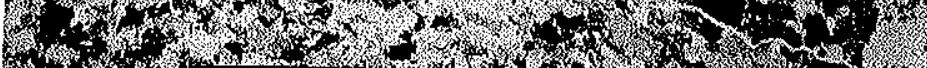

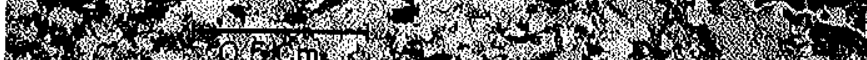

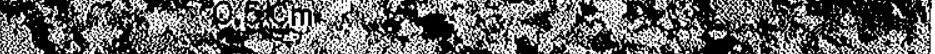
1.9. 7.
Foto 10

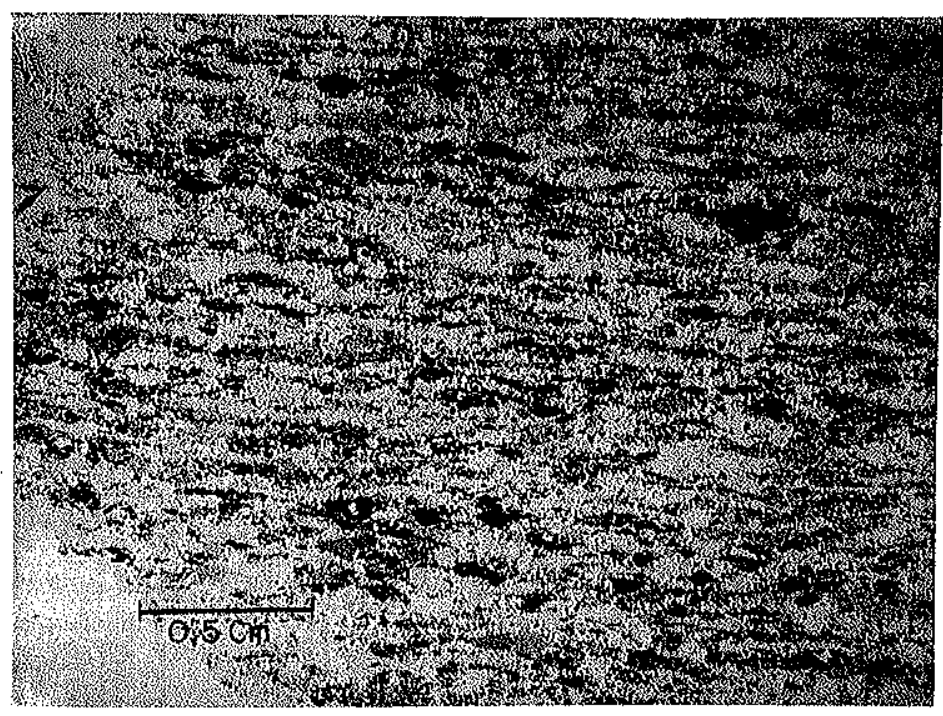

Foto 12 
FOTO 13 - Fotomicrografia. Nicöis cruzados. "Granitóide", Bloco NW. Textura granoblástica, grosseira, não deformada, com quartzo, plagiocläsio, biotita, muscovita (rara), microclíneo, zircão e apatita.

FOTO 14 - Fotomicrografia. Nicóis cruzados. "Granitóide", Zona de Transição SE. Textura granoblāstica,grós seira, com deformação incipiente. Notar texturas em moldura nas bordas dos grãos maiores. Quartzo com forma planar pouco desenvolvida. Matriz in tersticial, às vezes com texturas de equilíbrio, de microclíneo, quartzo, biotita e plagioclāsio.

FОто 15 - Fotomicrografia. Nicöis cruzados. Milonito-gnais se tipo "b", Zona de Transição SE.Porfiroclastos de mesopertita, pertita e plagioclásio. Quartzo com forma planar pouco desenvolvida. Matriz, com texturas de equiliborio, de microclíneo,plagiocla á sio, biotita ocorrendo tambēm granada (xenomorfa).

FOTO 16 - Fotomicrografia. Nicóis cruzados. Milonito-gnais se tipo "a", Zona Principal de Deformação. Por firoclastos de pertita e plagioclásio; quartzo planar; matriz com texturas de equilíbrio de pla gioclāsio, quartzo, biotita, muscovita, apatita.

FOTO 17 - Fotomicrograifa. Nicóis cruzados. Blastomilonito tipo "b", Zona Principal de Deformação. Porfiro clastos de plagioclásio, hiperstênio, opacos; quartzo planar; matriz com texturas de equili brio de plagioclásio, quartzo, biotita e apatitá. Notar os "cordões" de quartzo, formados por agre gados planares de grãos com ângulos de extinção diferentes.

FOTO 18 - Fotomicrografia. Nicóis cruzados. Blastomilonito tipo "a", Zona Principal de Deformação. Porfiro clastos pequenos de plagioclásio e mesopertita; quartzo planar; matriz com texturas de equilí brio de microclīneo, plagioclāsio, biotita, opạ . cos; a biotita encontra-se às vezes deformada. 


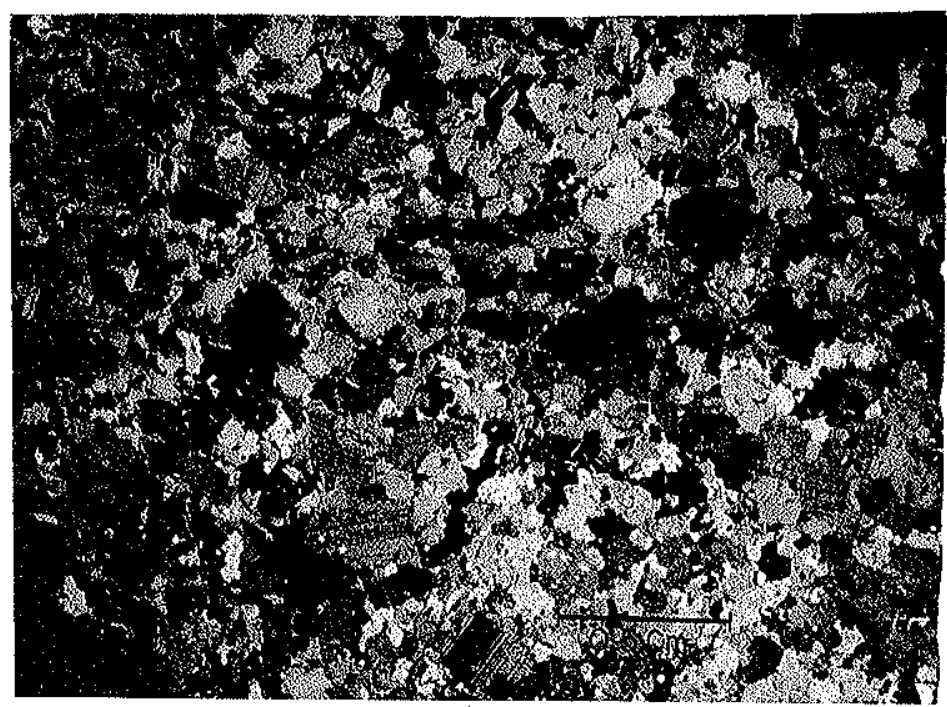

Foto 13

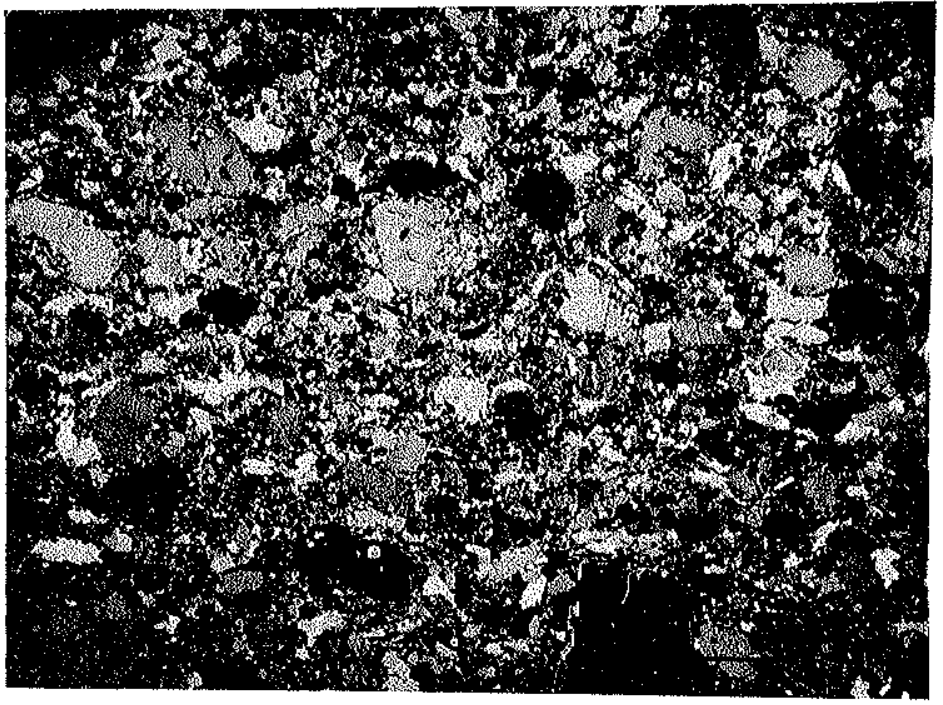

Foto 15

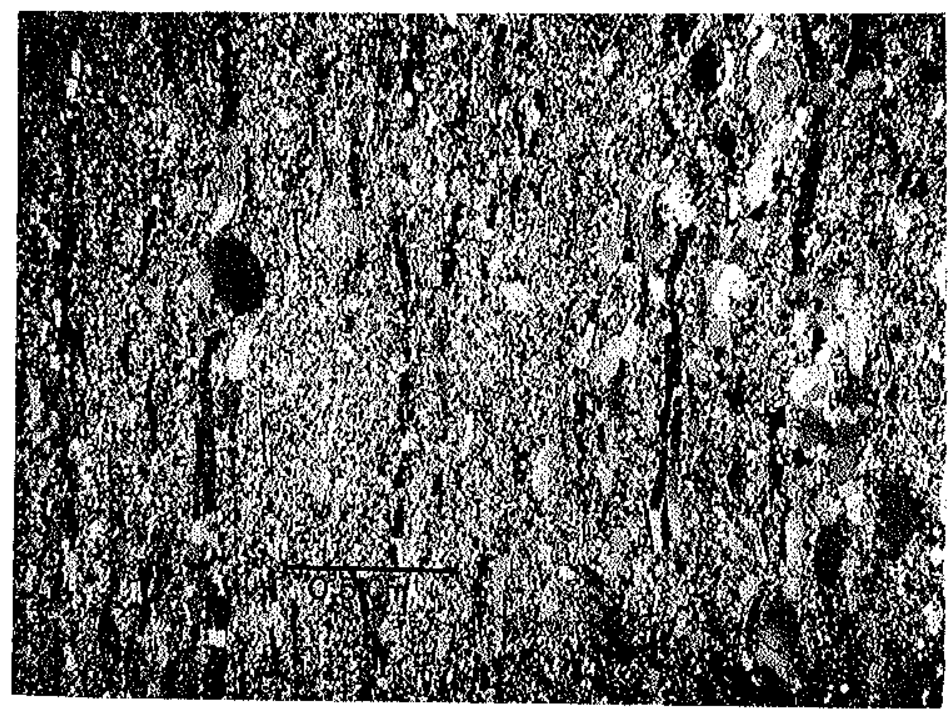

Foto 17

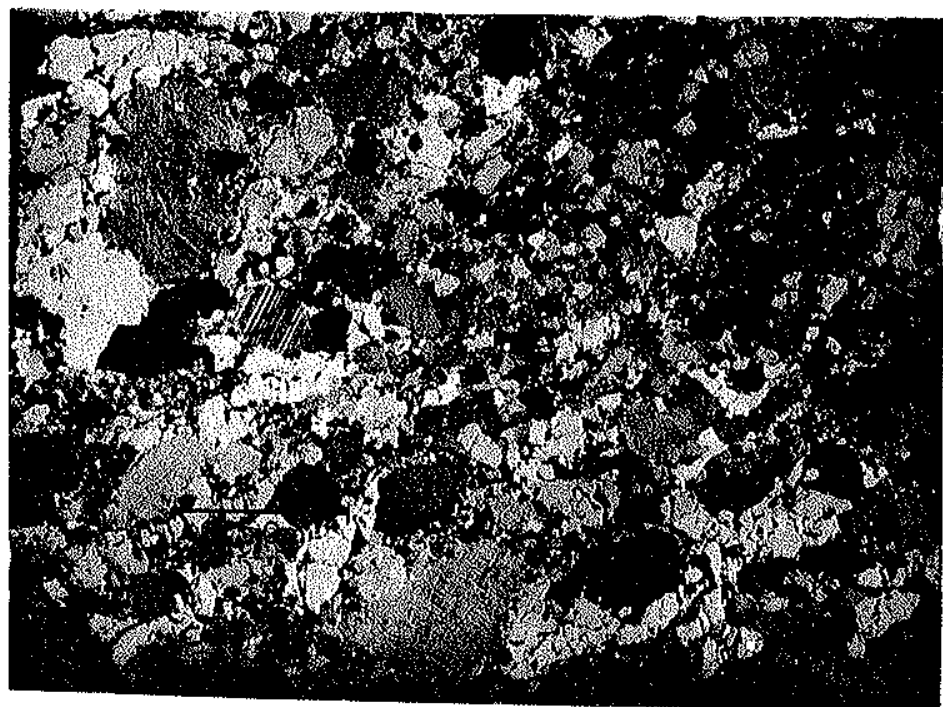

Foto 14

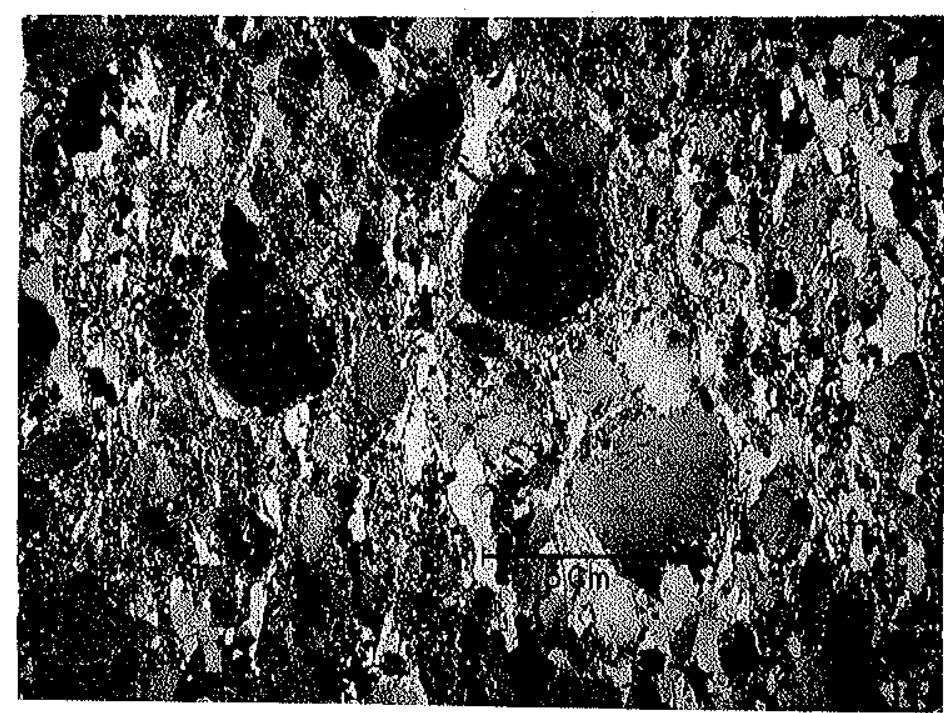

Foto 16

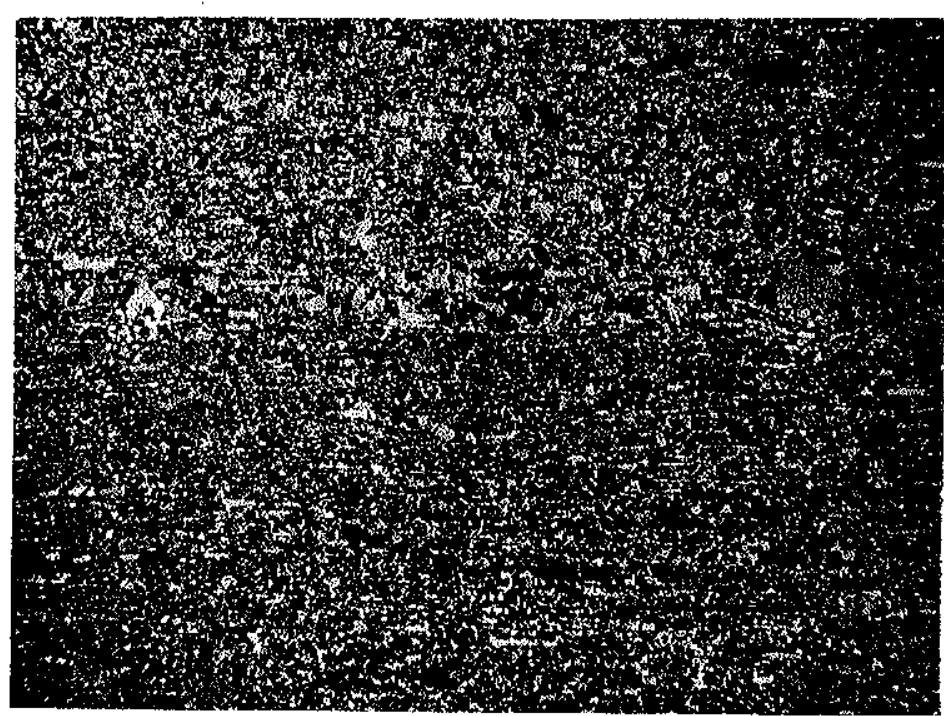

Foto 18 


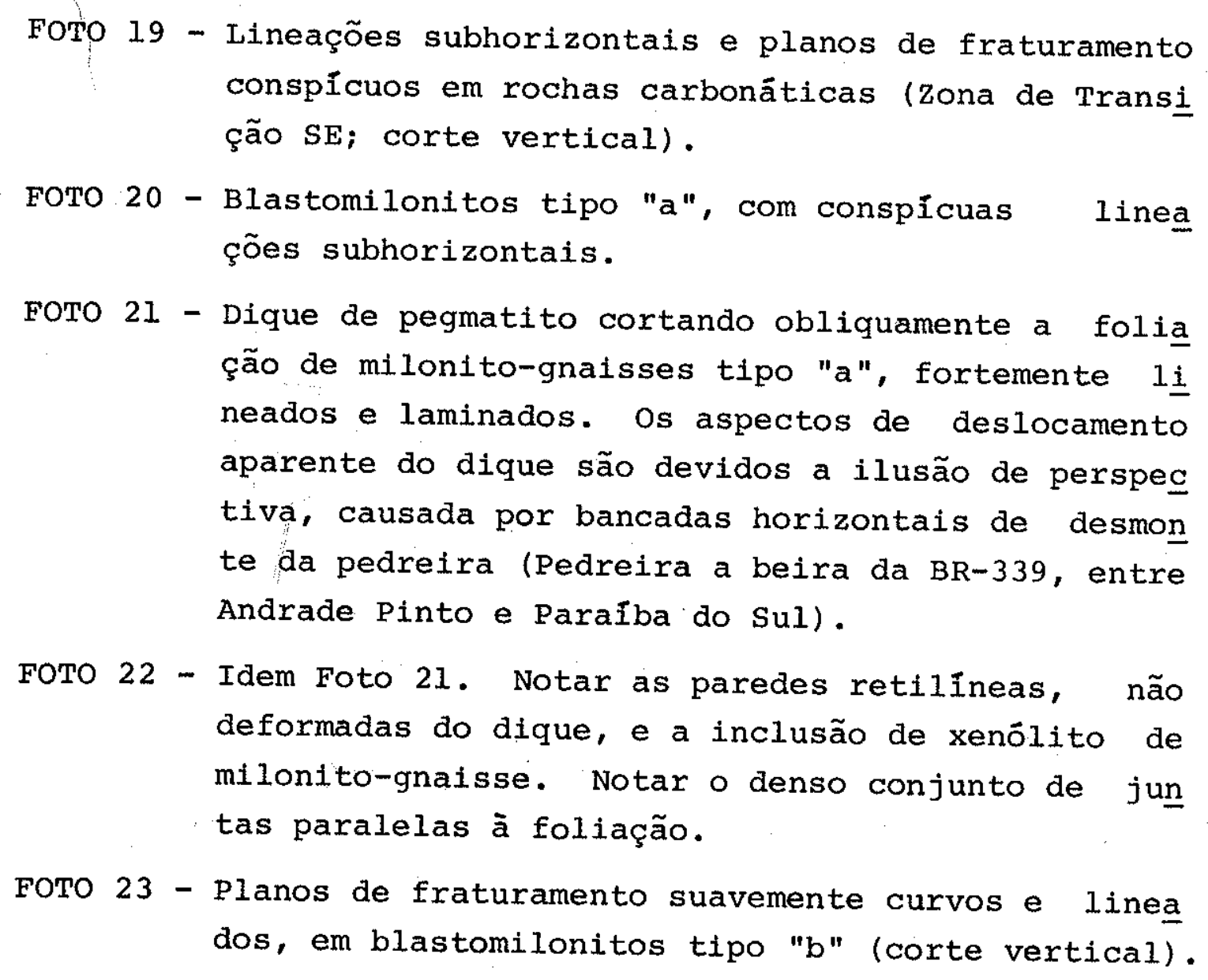




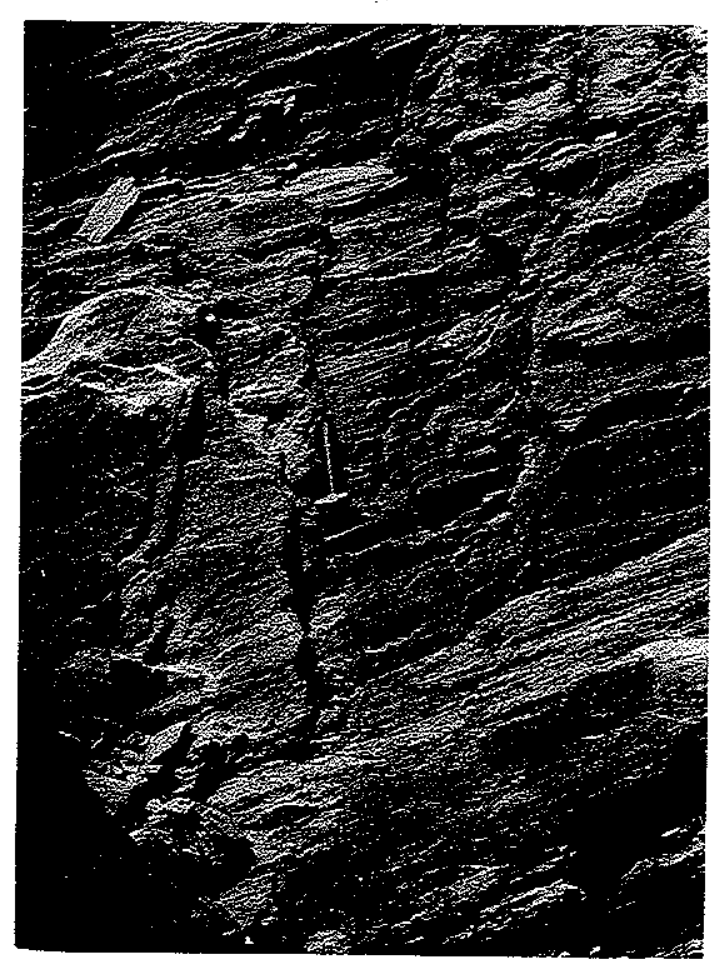

Foto 19

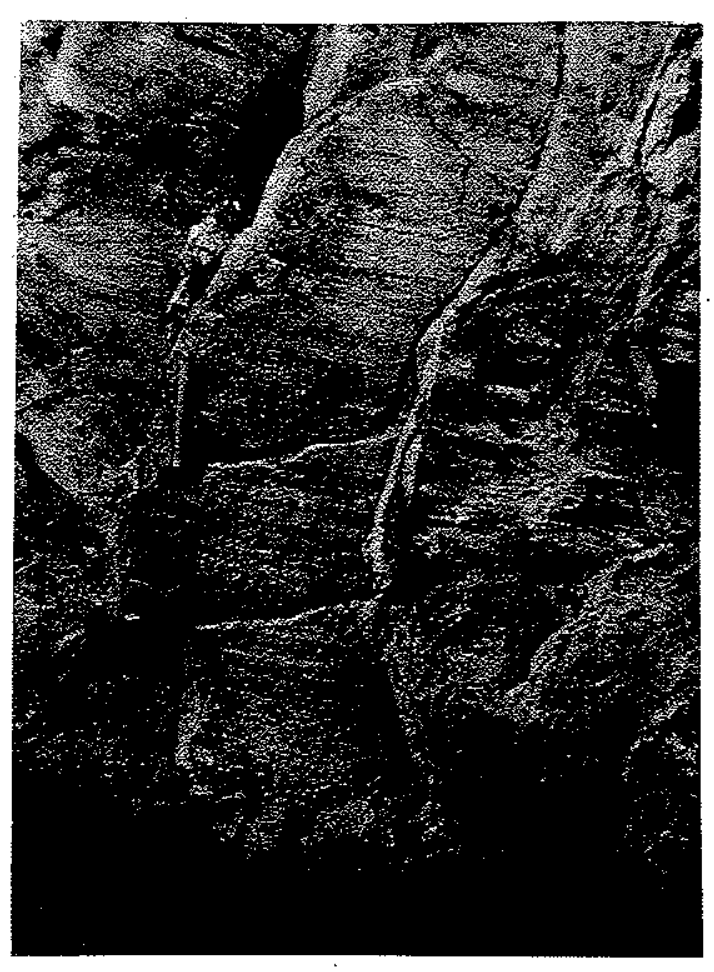

Foto 20

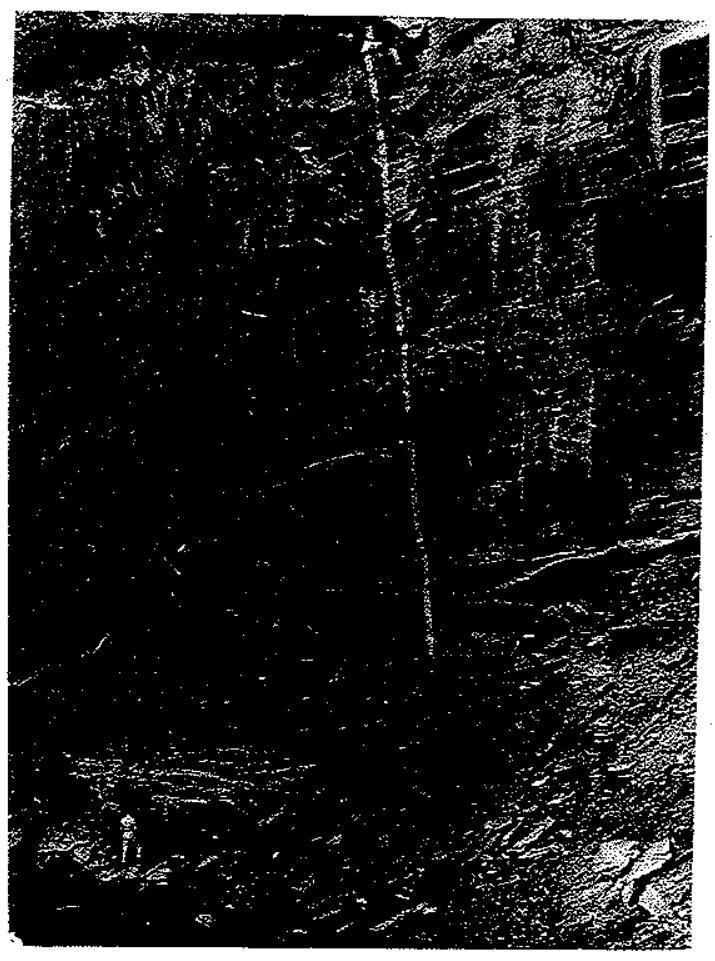

Foto 21

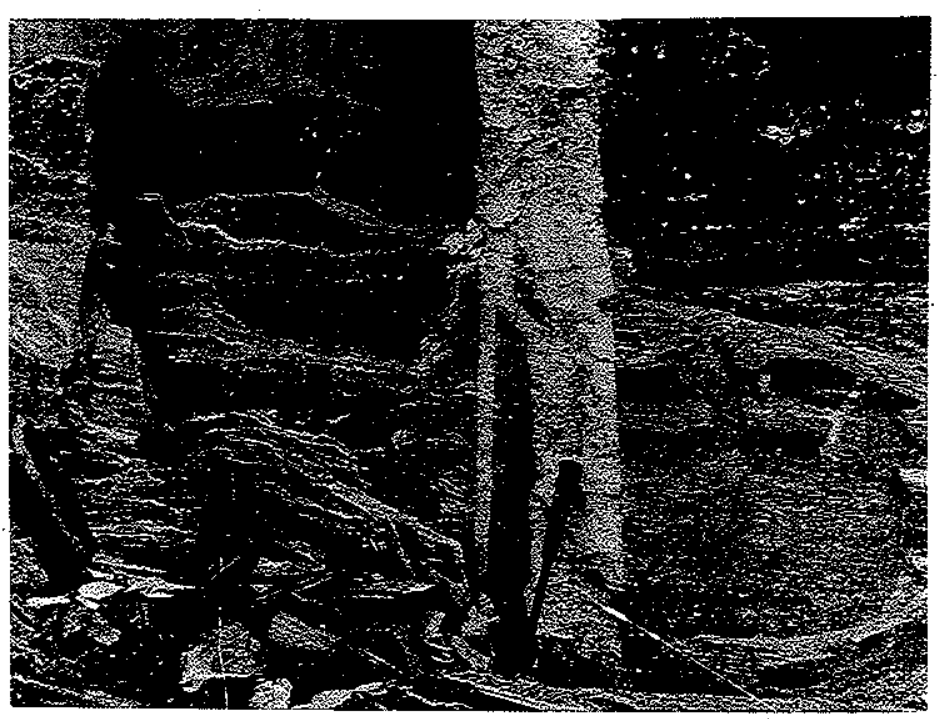

Foto 22

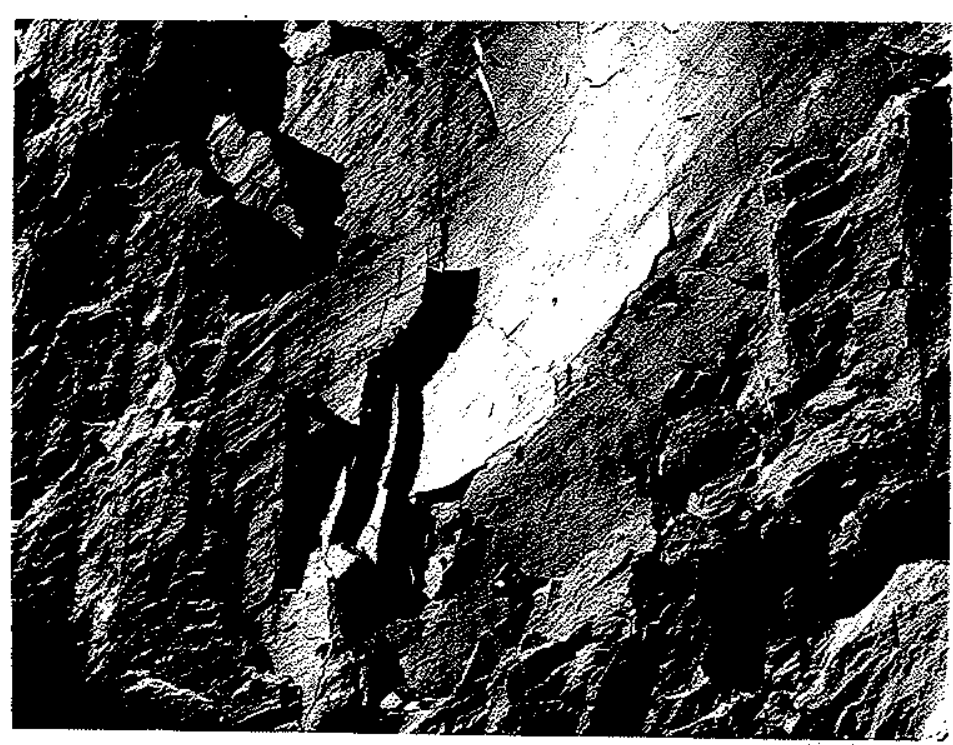




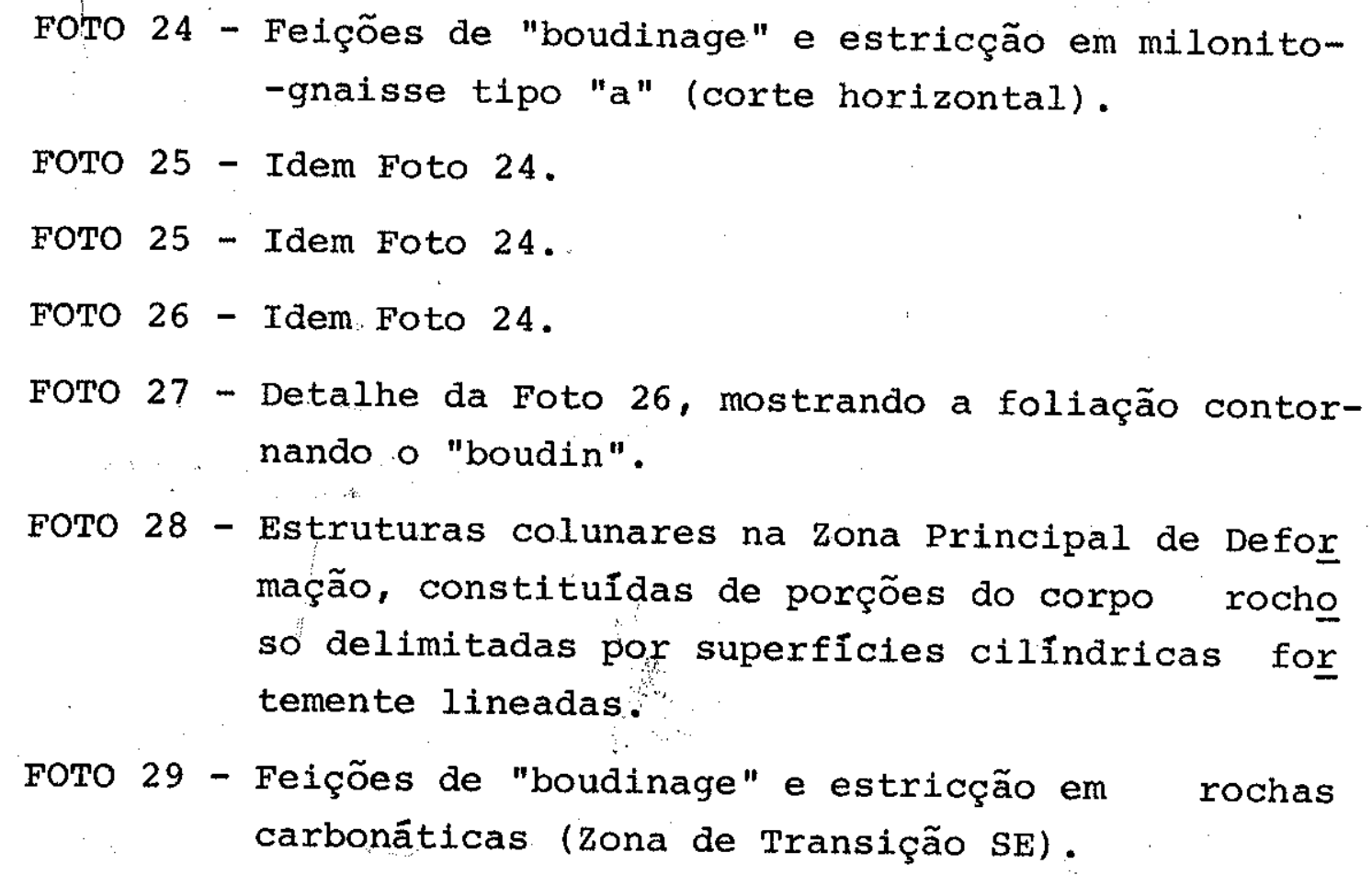
mação, constituídas de porções do corpo rocho so delimitadas por superfícies cilindricas for temente lineadas.

FOTO 29 - Feições de "boudinage" e estricção em rochas carbonāticas (Zona de Transição SE). 


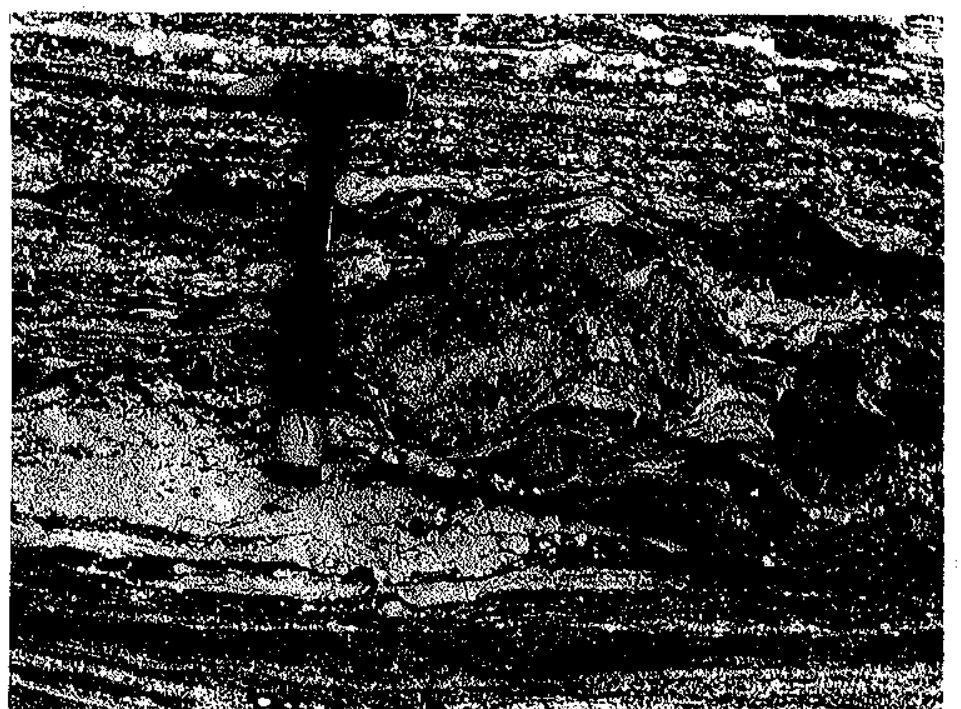

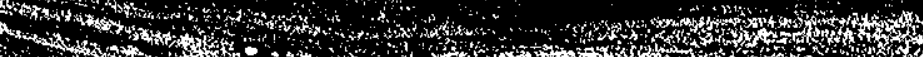

Foto 24

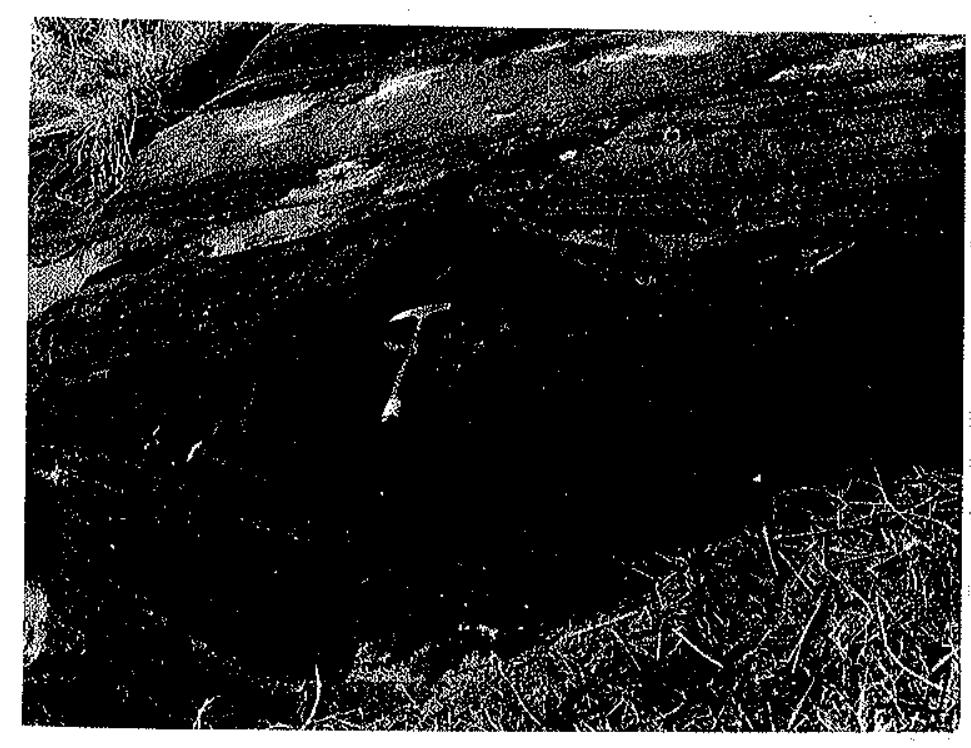

Foto 26

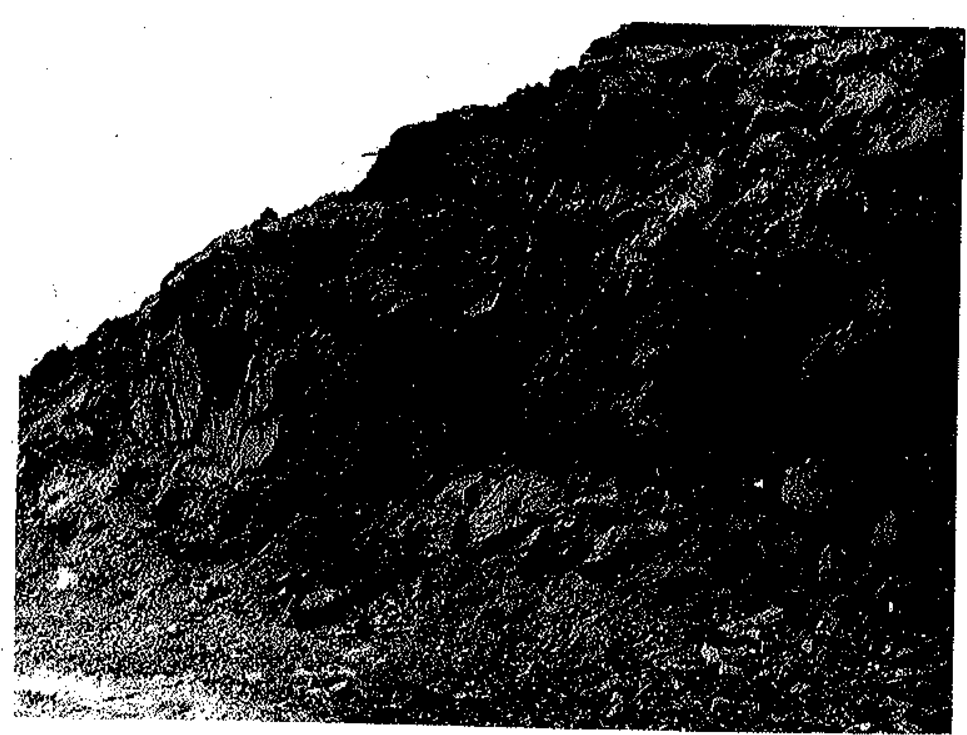

Foto 28

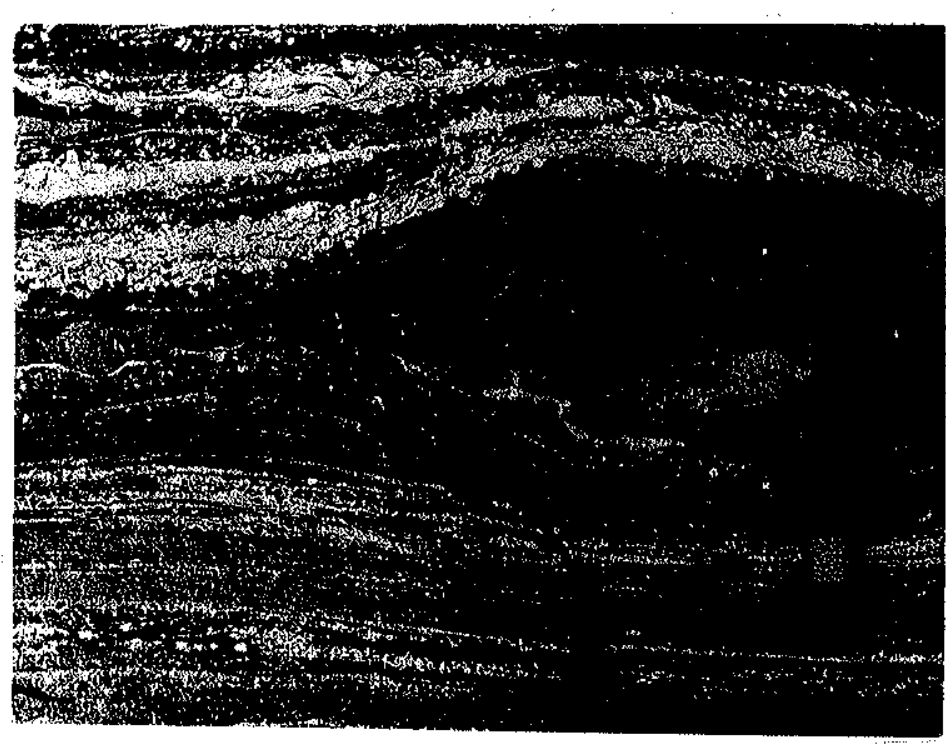

Foto 25

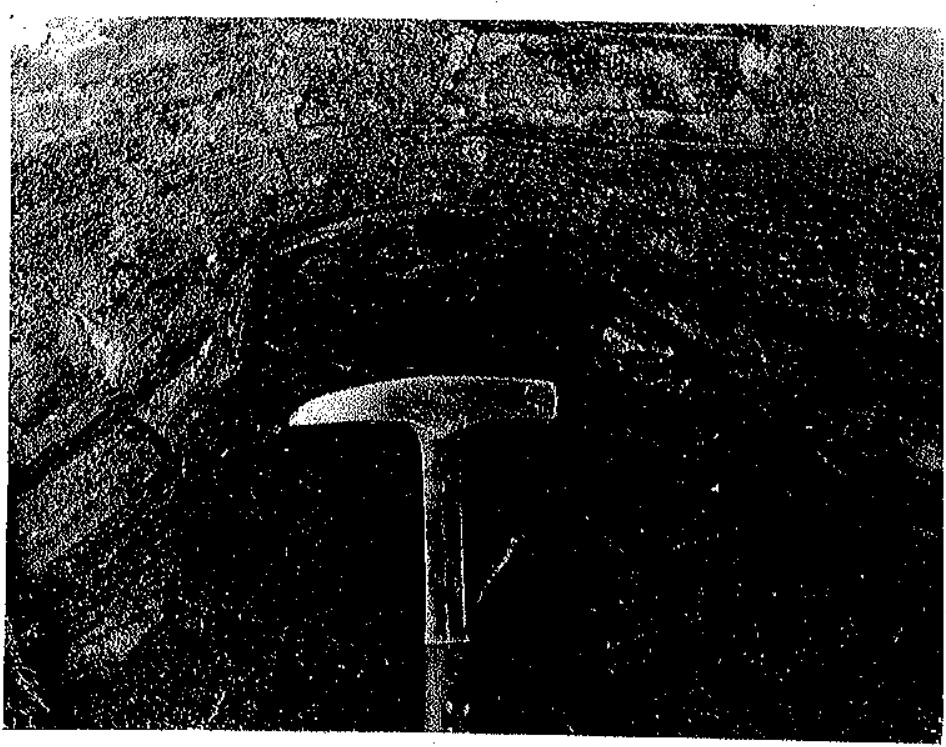

Foto 27

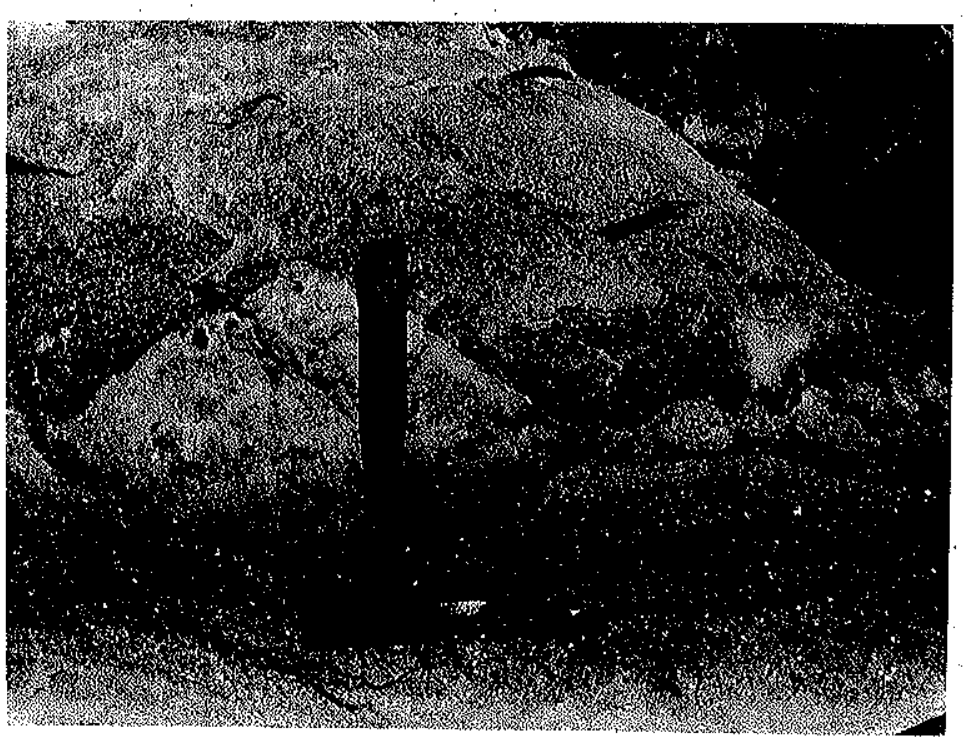

Foto 29 
FOTO 30 - Apice de dobra intrafolial, isolado em meio à in tensa foliação de milonito-gnaisses tipo "a" (cor te vertical, Zona Principal de Deformação).

FOTO 31 - Dobra recumbente em quartzitos do Bloco SE (corte vertical).

FOTO 32 - Detalhe da Foto 31. Foliação subvertical sobre posta ao dobramento recumbente (corte vertical).

Fото 33 - Estilo de dobramento e transposição da zona prin cipal de Deformação, em blastomilonitos tipo "b" (corte vertical).

FOTO 34 - Idem Foto 33. Notar na parte superior da foto, possivel feição de redobramento (corte vertical). 


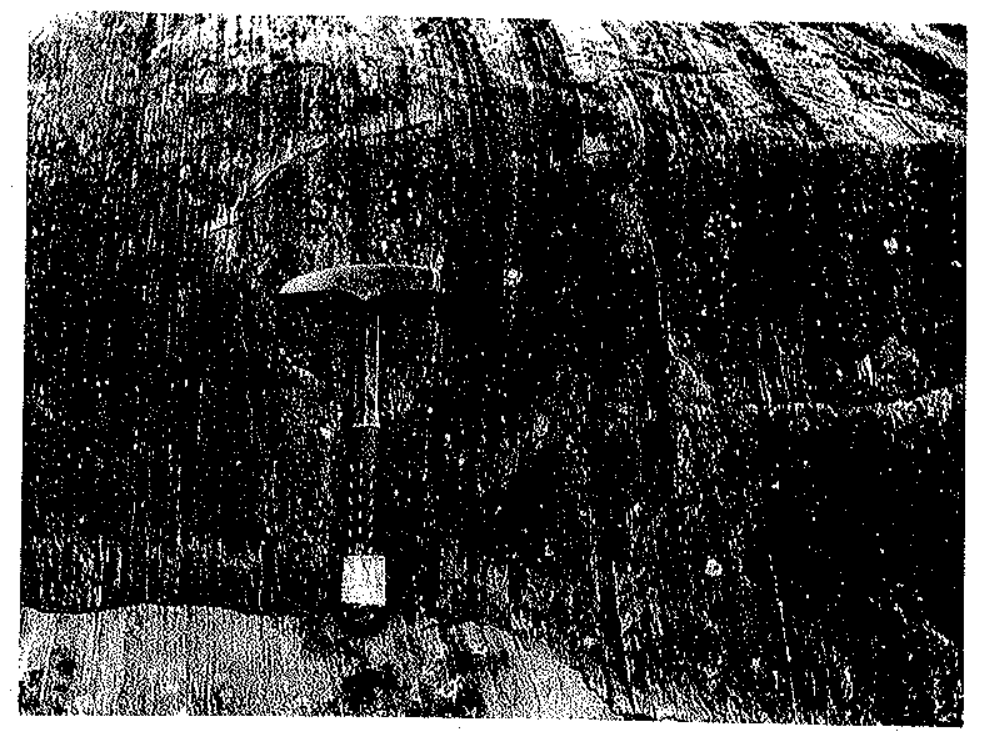

Foto 30

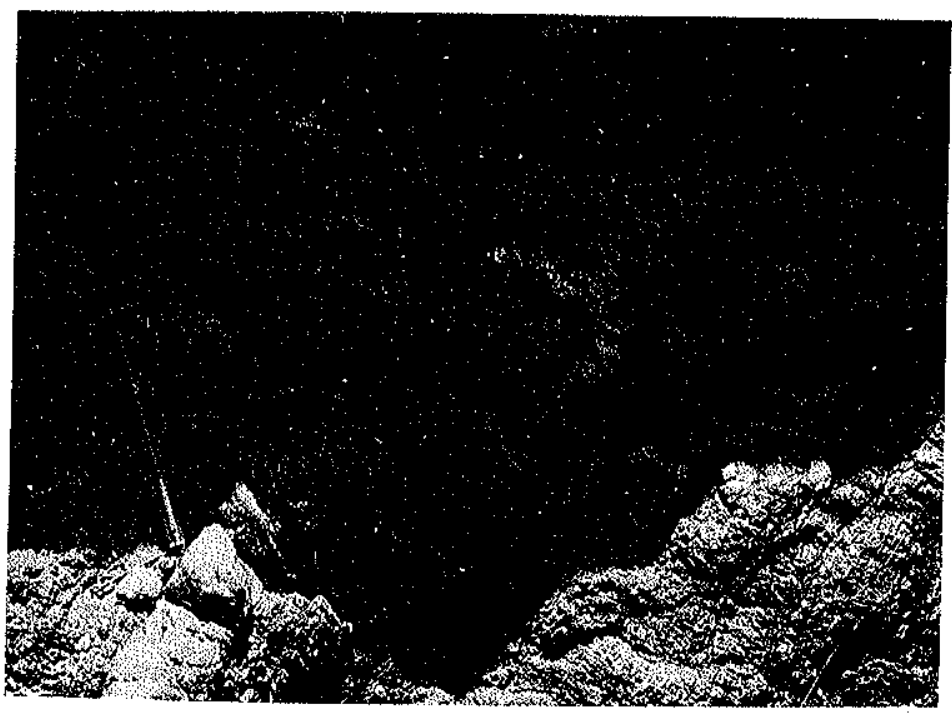

Foto 31

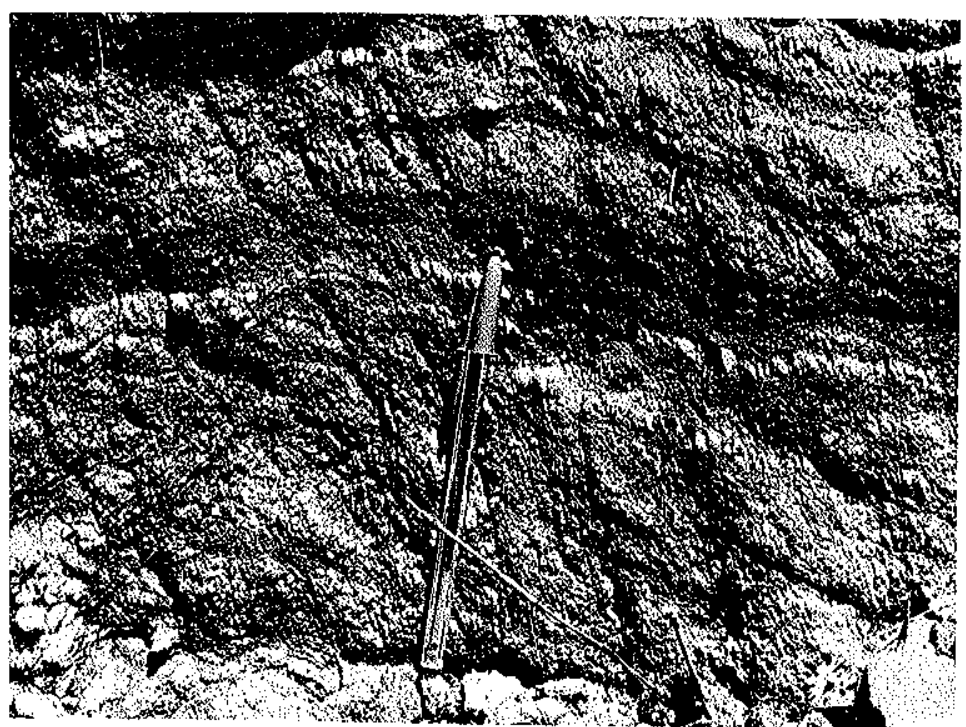

$$
\text { ruto } 32
$$

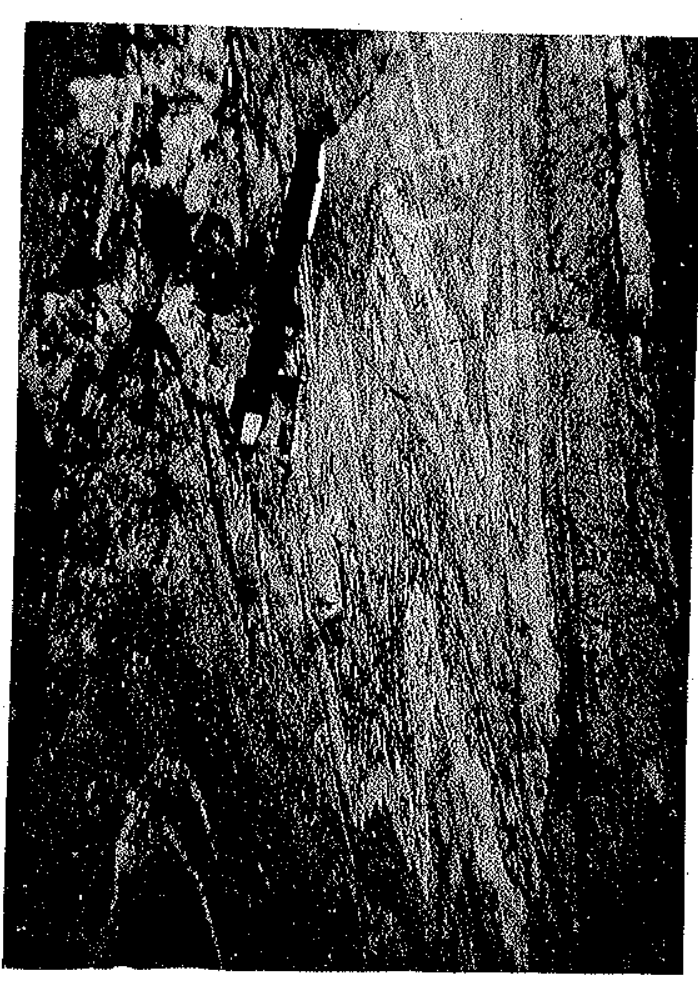

Foto 33

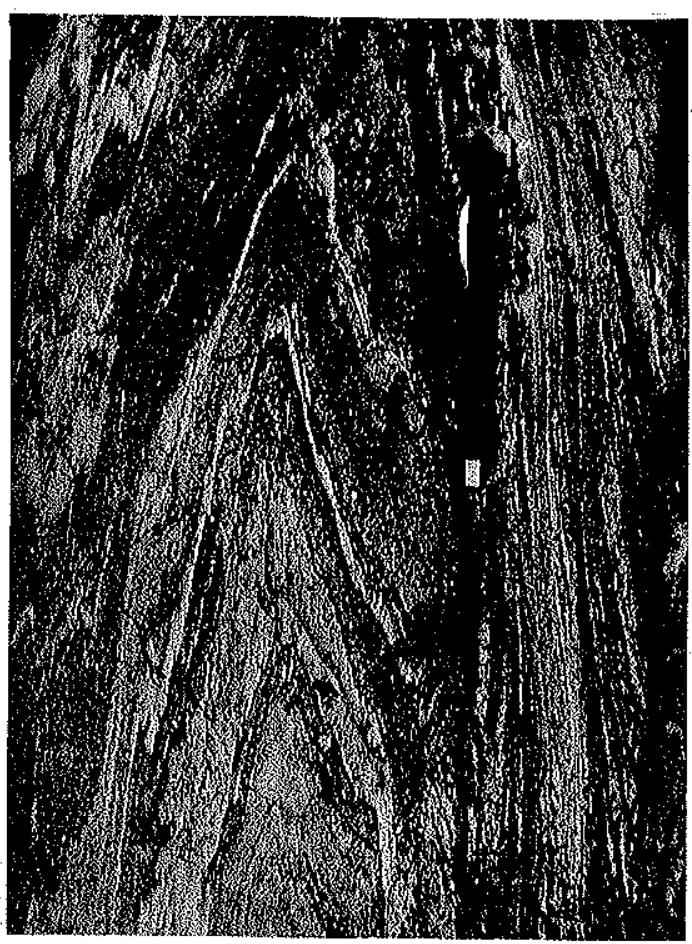

Foto 34 
FOTOS 35 a 40 - Fotomicrografias de seções delgadas de ápice de dobra intrafolial de milonito-gnaisse tipo "a", cujas orientações encontram-se ilustradas na Figura 9. A estrutura que encontra-se dobrada é o bandamento composicional da rocha, constituído por bandas com associações distintas de porfiroclas tos. As seções das Fotos 35, 37 e 39 correspondem a uma bañ da "félsica", e as das Fotos 36, 38 e 40 a uma banda "mäfica".

FOTO 35 - Paralela ao perfil da dobra (perpendicular ao eixo de dobra). Niónis cruzados. Nota-se o ápice espessado e os flancos adelgaçados da banda dobrada, constituída de porfiroclastos de plagioclásio, agregados de quartzo com forma planar e matriz recristalizada de plagioclásio, intercalada entre bandas de granulação mais fina com maior proporção de piroxênios, anfibólios e biotita. Notar que os agregados de quartzo planar contornam os porfiroclastos, possuem uma posição plano-axial, e limitam-se a uma única banda, interrompendo-se nos limites desta. Nesta seção os porfiroclastos possuem formas elipticas ou semi-circulares.

FOTO 36 - Paralela ao perfil da dobra (perpendicular ao eixo). Nicóis paralelos. Bandas alternadas constituídas ou de agregado poligonizado de grãos de plagioclásio recristalizado, ou bandas com porfiroclastos de hornblenda, em matriz de hornblenda,pla giocláasio, quartzo e biotita. Notar a posição plano-axial daś lamelas (muito finas) de biotita e a forma semi-circular dos porfiroclastos.

FOTO 37 - Perpendicular ao plano-axial da dobra e paralela ao eixo (pla no bc). Nicóis cruzados. Notar os agregados de quartizo de for ma planar, constituídos de grãos com diferentes posições de extinção e contatos amebóides entre si; a forma elíptica a semi-circular dos porfiroclastos de plagioclásio e a matriz fina poligonizada.

FOTO 38 - Mesma posição que a seção da Foto 37. Niōiis paralelos. Bandas alternadas com predominância de porfiroclastos de hiperstênio ou de hormblenda, com matriz de plagioclásio, biotita e quart zo, e de bandas constituídas por agregado poligonizado de grãos de quartzo recristalizados. Notar a forma eliptica dos porfiro clastos e a orientação das lamelas (muito finas) de biotita.

FOIO 39 - Paralela ao plano-axial da dobra. Nicóis cruzados. Notar que os agregados de quartzo planar foram cortados paralelamente a sua forma planar. Os porfiroclastos de hornblenda e hiperstênio apresentam uma forma mais tabular, em comparação com os demais cortes, com maior elongação paralela ao eixo de dobra. Os grãos dos agregados poligonizados de plagioclásio e quartzo continuam a ter formas tendendo a hexagonais.

FOTO 40 - Mesma posição que a Foto 39. Nicóis paralelos. Notar a forma tabular dos porfiroclastos de hornblenda, com elongação paralela ao eixo de dobra, e a forma hexagonal dos grãos dos agre gados poligonizados de plagiocläsio. 


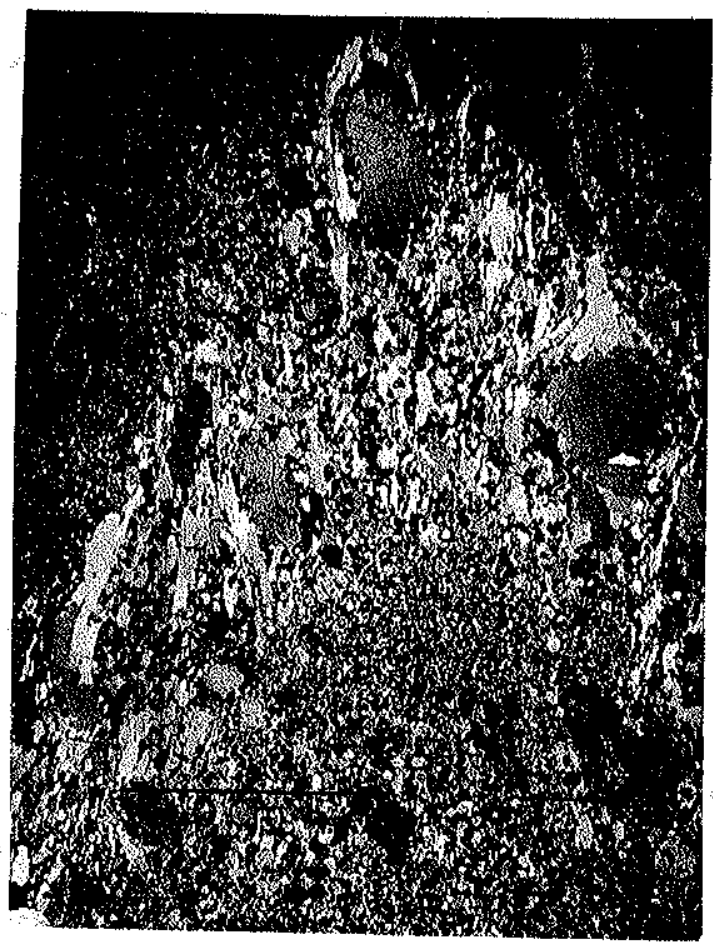

F'oto 35

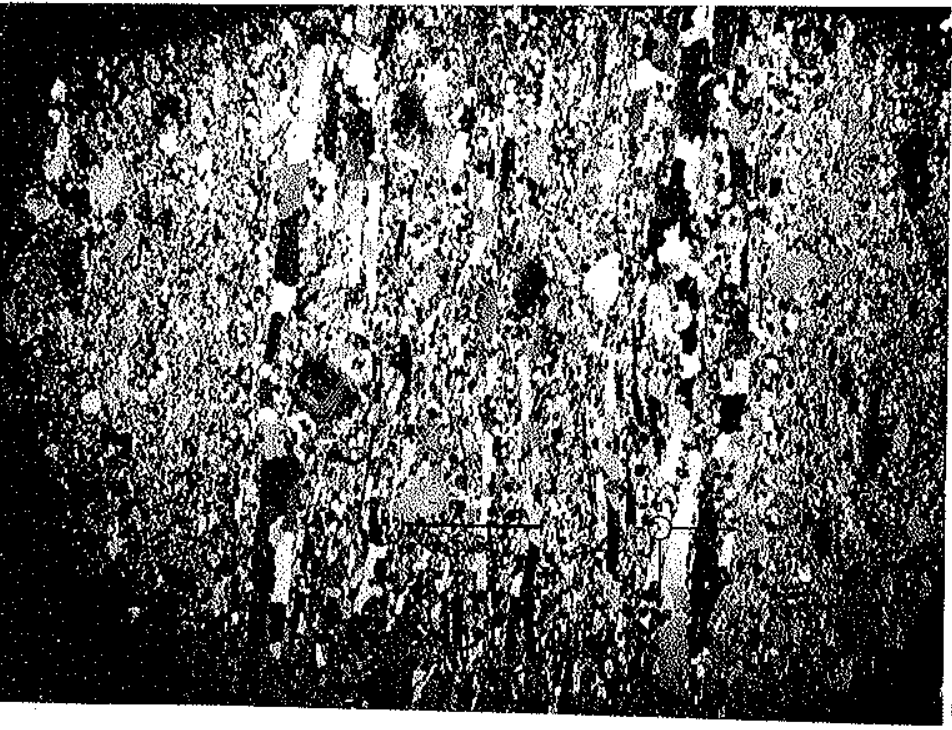

Foto 37

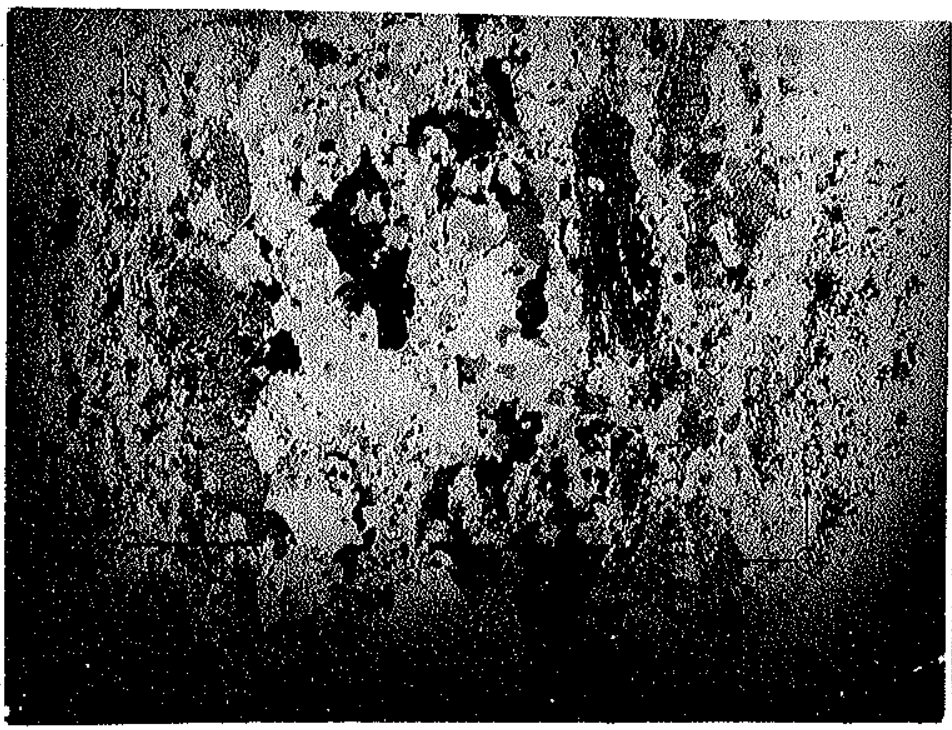

Foto 39

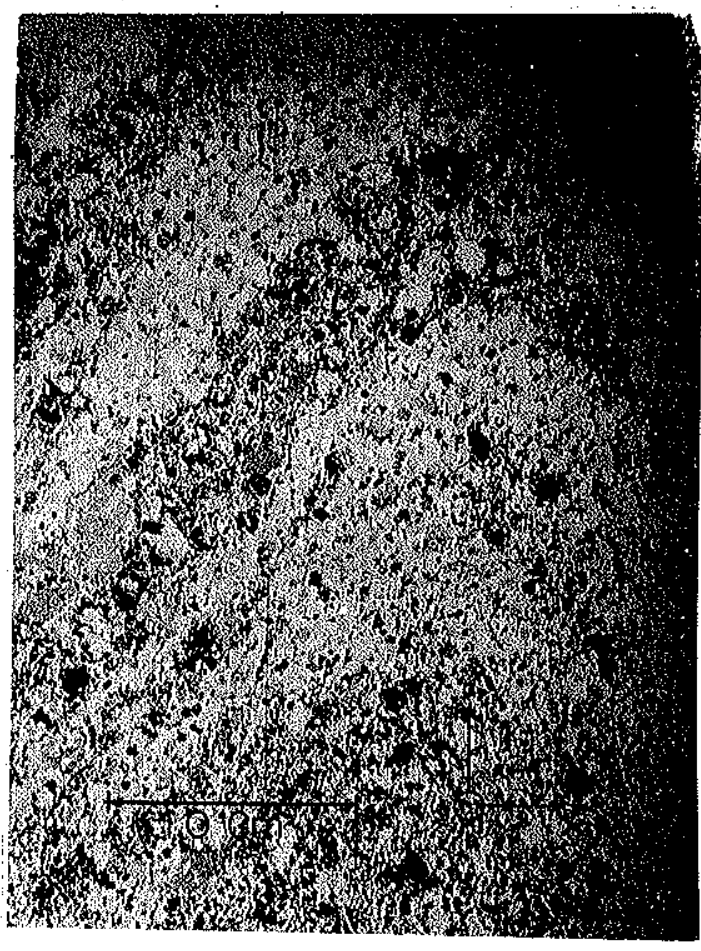

Foto 36

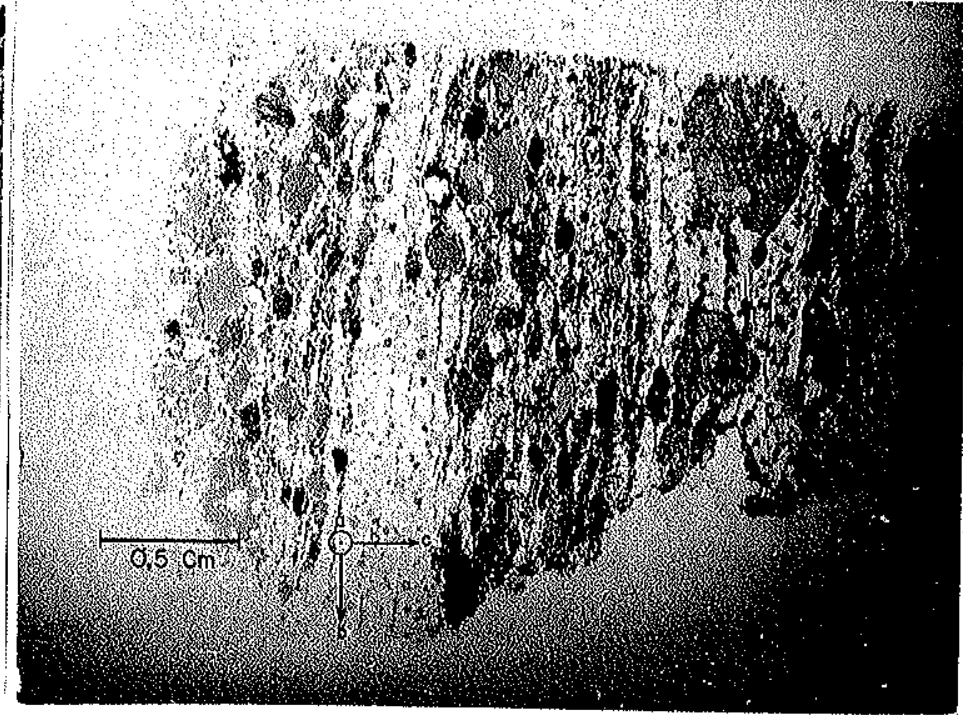

Foto 38

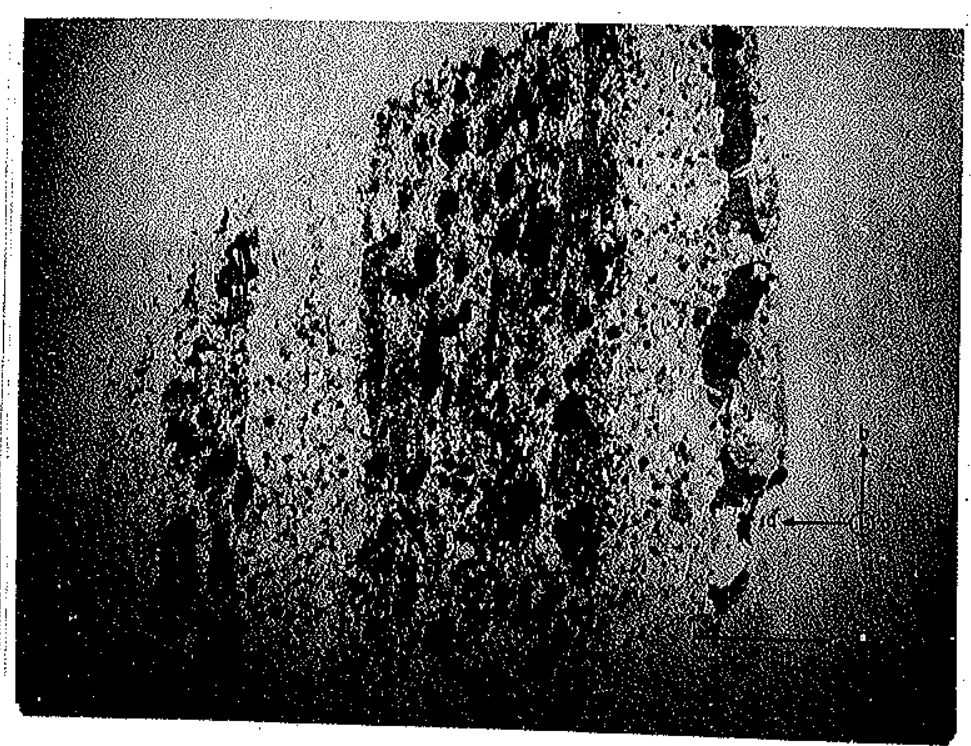

Foto 40 
FOTO 41 - Falha de empurrão em rochas carbonáticas. O bloco cavalgante apresenta-se bastante amarrotado, ten do sofrido deslocamento na base (Zona de Transi ção $\mathrm{SE}$ ) .

FOTO 42 - Fotomicrografia. Nicóis cruzados. Milonito-gnais se com feições de redeformação. Porfiroclastos de antipertita; quartzo planar dobrado e com extin ção ondulante; matriz granoblástica, de plagioclā sio, microclineo, quartzo, biotita, às vezes com texturas de equilíbrio, sem extinção ondulante, ou tras vezes com grãos de quartzo, microclíneo, pla gioclásio e biotita deformados.

FOTO 43 - Fotomicrografia. Nicóis cruzados. Milonito-gnaisse. Notar a existência de duas foliações, sendo a mai's antiga crenulada e rotacionada, dando origem a mais nova. Porfiroclastos de hornblenda, diopsi dio, hiperstênio, plagioclásio; a matriz apresen ta-se com texturas de equilibrio; os planos de cí salhamento são constituídos por agregados de gra nulação mais fina, tambēm com texturas de equili brio bem desenvolvidas.

FOTO 44- Blastomilonitos tipo "a", englobando "boudin" de milonito-gnaisse, com foliação às vezes discordan te. Notar que o milonito-gnaisse do "boudin" apre senta bandamento dobrado e transposto, não sendo essas feições visiveis no blastomilonito mais $f \underline{i}$ no circundante (Zona Principal de Deformação).

FOTO 45 - Blastomilonitos tipo "b", com foliação afetada por planos de crenulação (Pedreira Moura Brasil ou Tabaiara). 


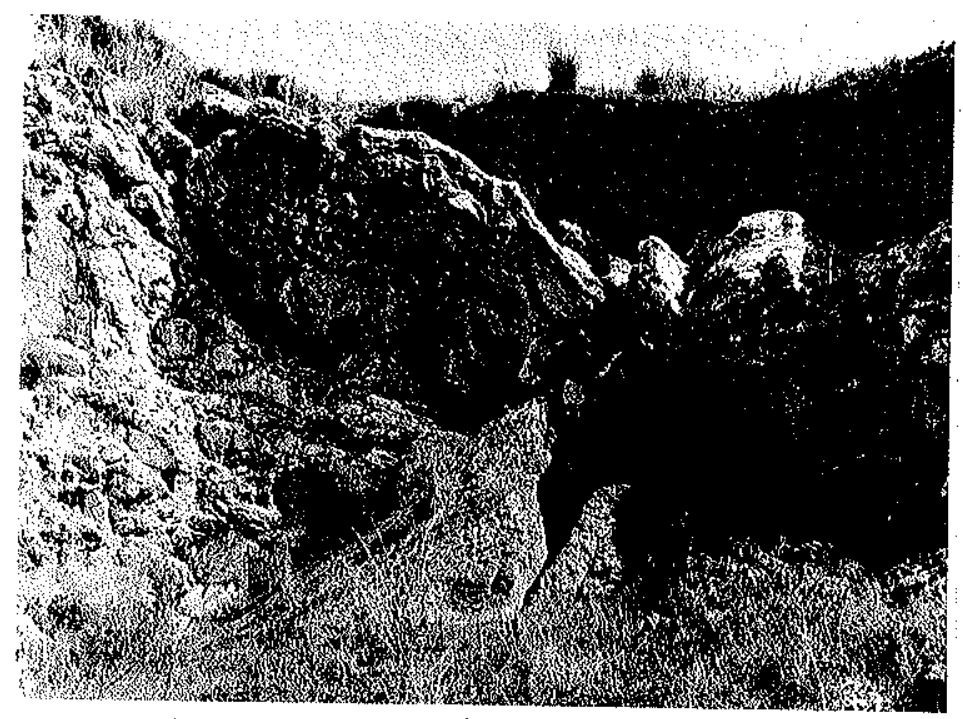

Foto 41
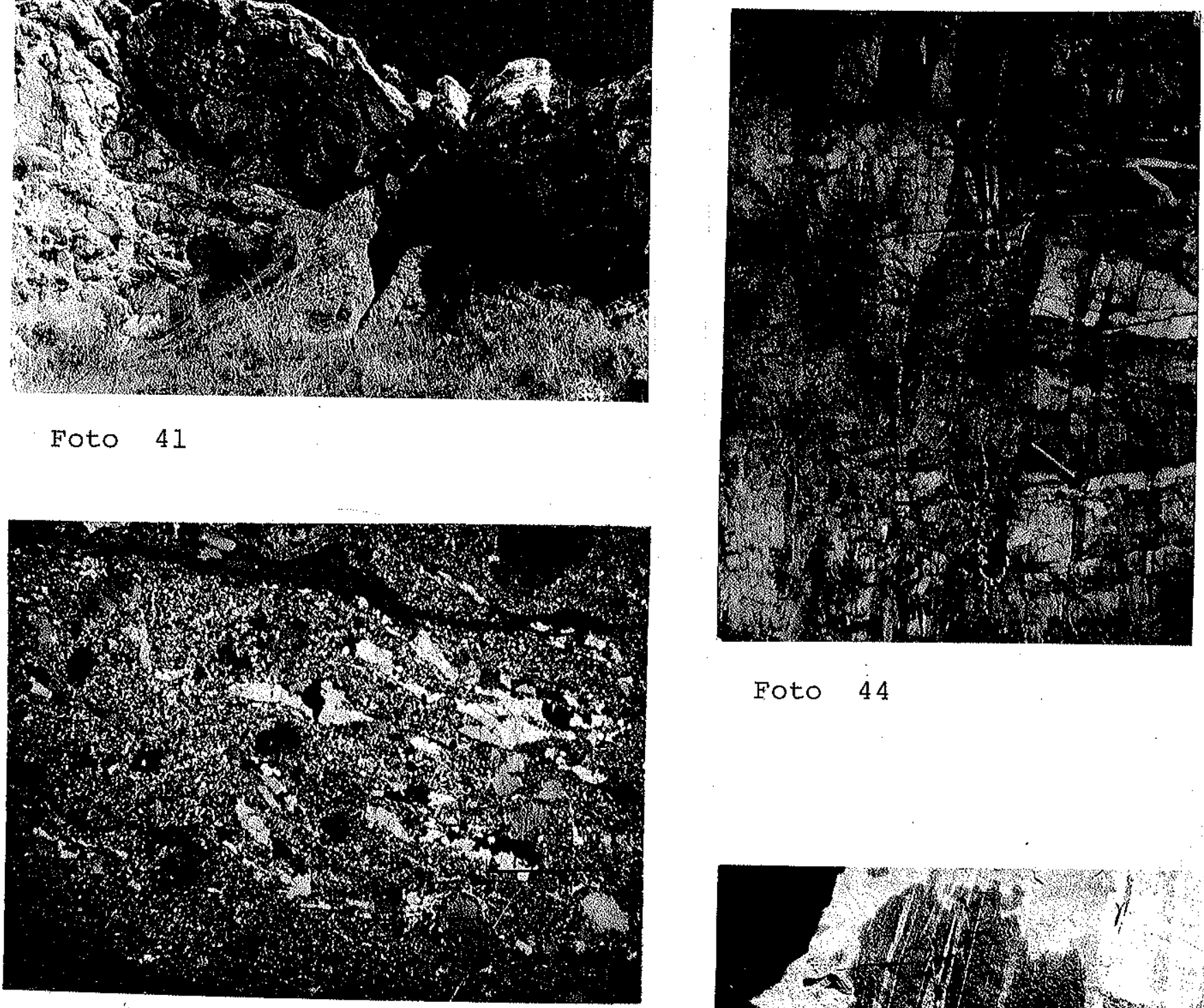

Foto 44

\section{Foto 42}
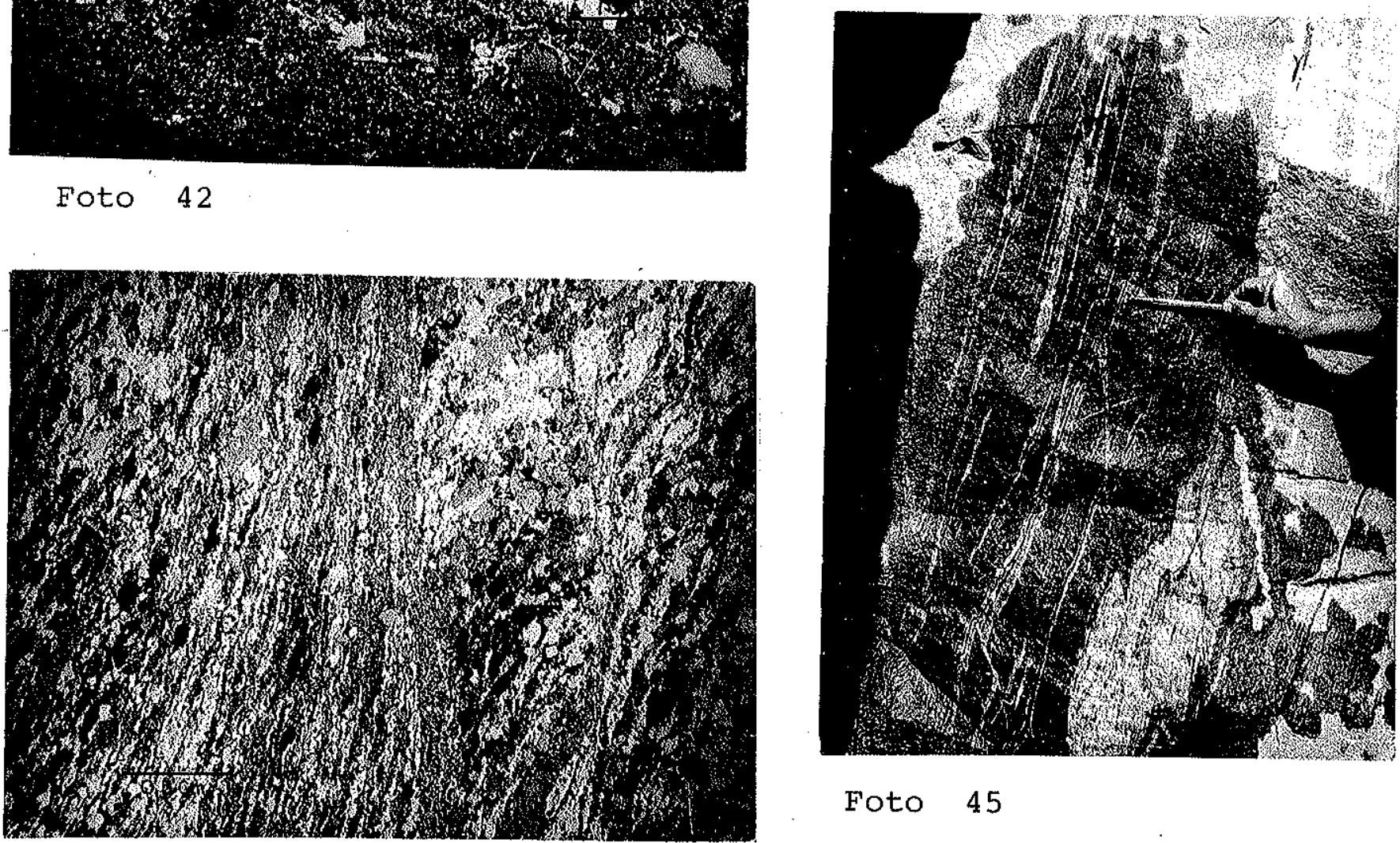

Foto 45

Foto 43 
FOTO 46 - Neossoma pegmatítico penetrando por plano de trans posição de blastomilonitos tipo "b", na zona Prin cipal de Deformação (Pedreira Moura Brasil ou Ta baiara; corte vertical).

FOTO 47 - Neossoma quartzo-feldspático em blastomilonitos tí po "b", apresentando lineações subhorizontais (Pe dreira Moura Brasil ou Tabaiara).

FOTO 48 - Estruturas de intensa ductibilidade na zona Prin cipal de Deformação. As partes escuras (paleossoma) correspondem a blastomilonitos básicos, em meio a porção mais clara, de neossoma quartzo-feldspāticos e blastomilonitos "félsicos" remobilizados (Pedre ra Moura Brasil ou Tabaiara; corte vertical).

Fото 49 - Estrutura agmatítica, com paleossoma granulítico e/ou blastomilonitico. Dique estreito de lamprófi ro corta o conjunto (Pedreira Moura Brasil ou Ta baiara; corte vertical).

Fото 50 - Fotomicrografia. Nícóis paralelos. Milonito-gnais se migmatizado. O paleossoma constituí-se de milo nito-gnaisse com porfiroclastos de hiperstênio,pla gioclásio, diopsỉdio, apatita, opacos, hornblenda (resultante da alteração de piroxênios), e matriz fina granoblástica, com texturas de equilibrio,com plagioclásio e biotita. O neossoma (leucossoma) apresenta textura equigranular, grosseira, porém com feições de deformação (extinção ondulante, ge minações e clivagens encurvadas, interstícios en tre os grãos maiores preenchidos por matriz fina, com texturas de equilíbrio); tanto os grãos maio res como a matriz são constituídos basicamente de plagioclásio e quartzo; observa-se ainda melanosso ma biotitico orlando o paleossoma, e raros porfiro clastos de hiperstênio em meio ao leucossoma. As feições de deformação no paleossoma são conspícuas, e no leúcossoma incipientes. 


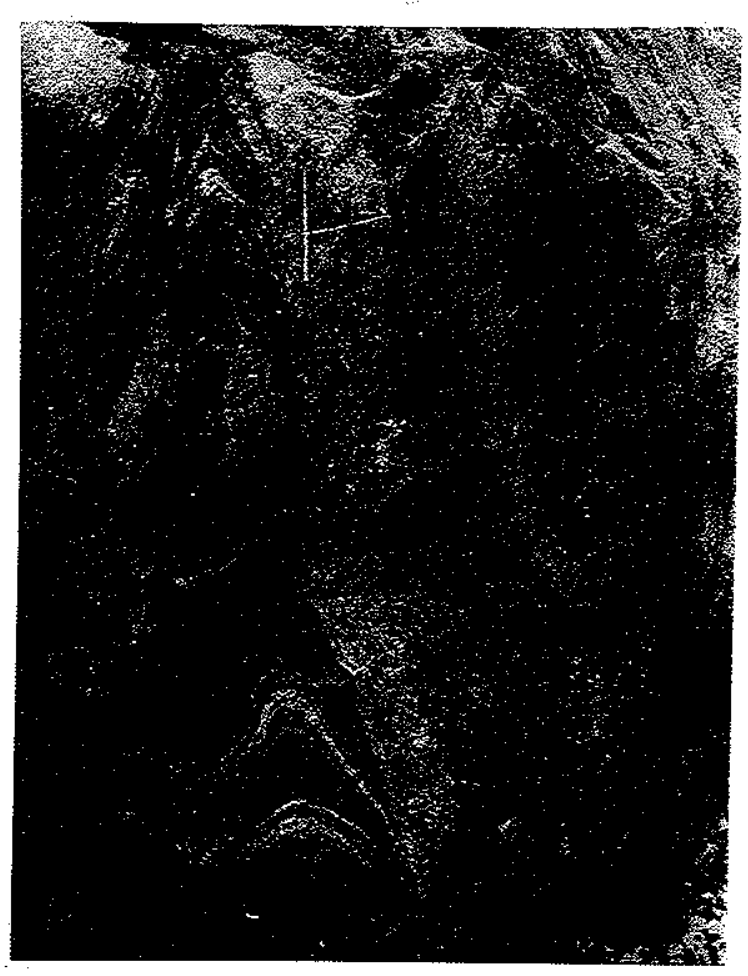

Foto 46

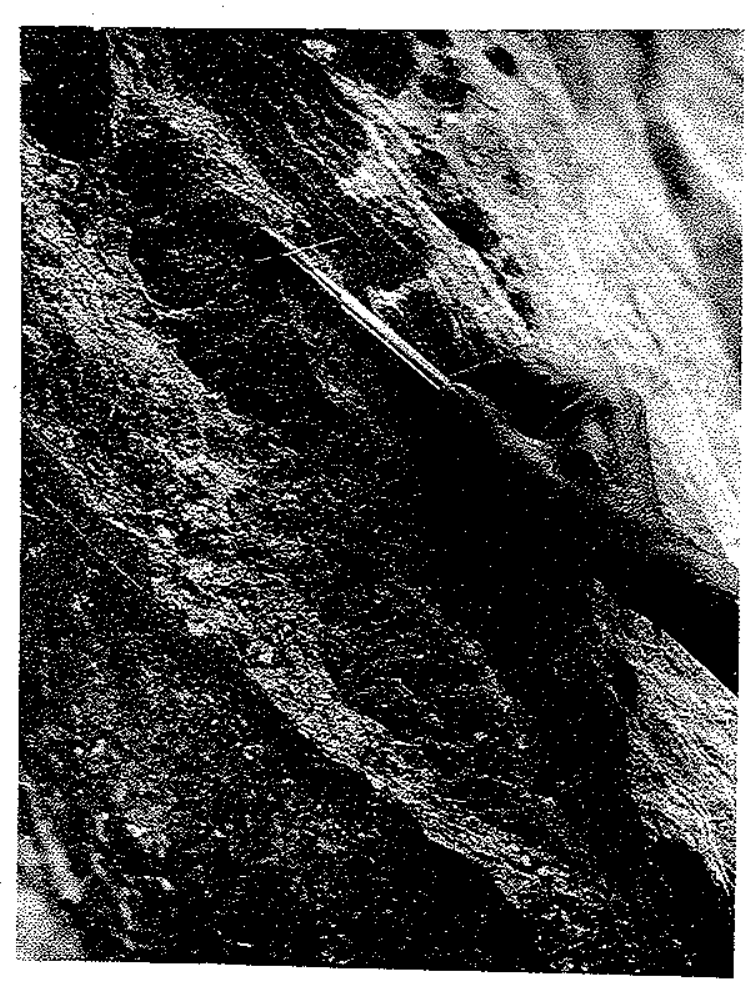

Foto 47

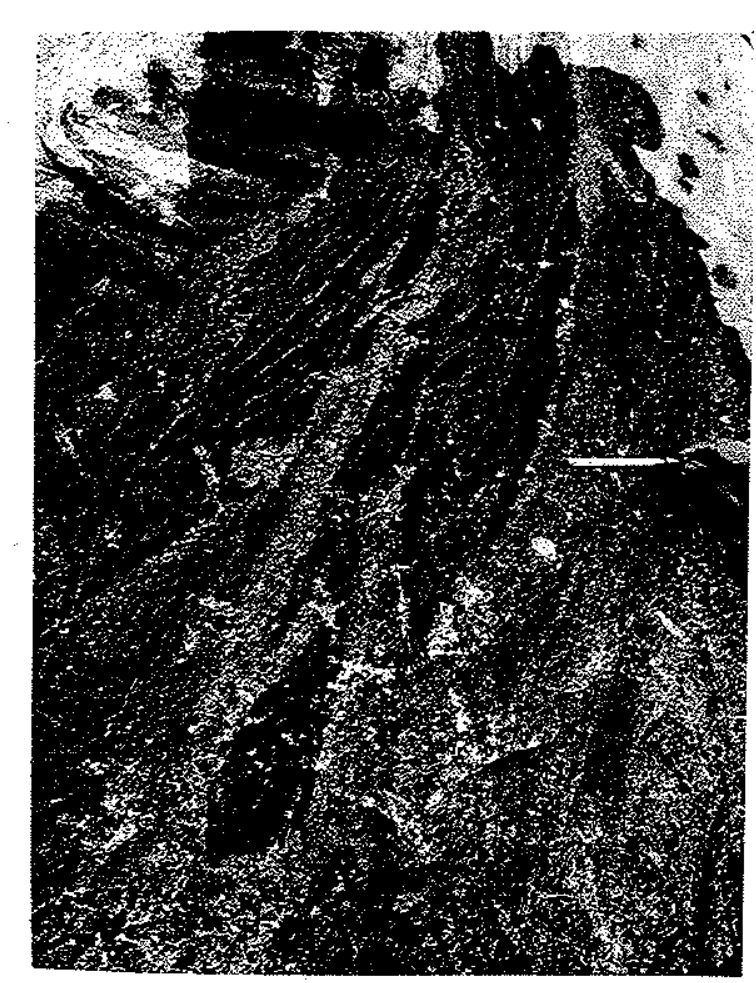

Foto 48

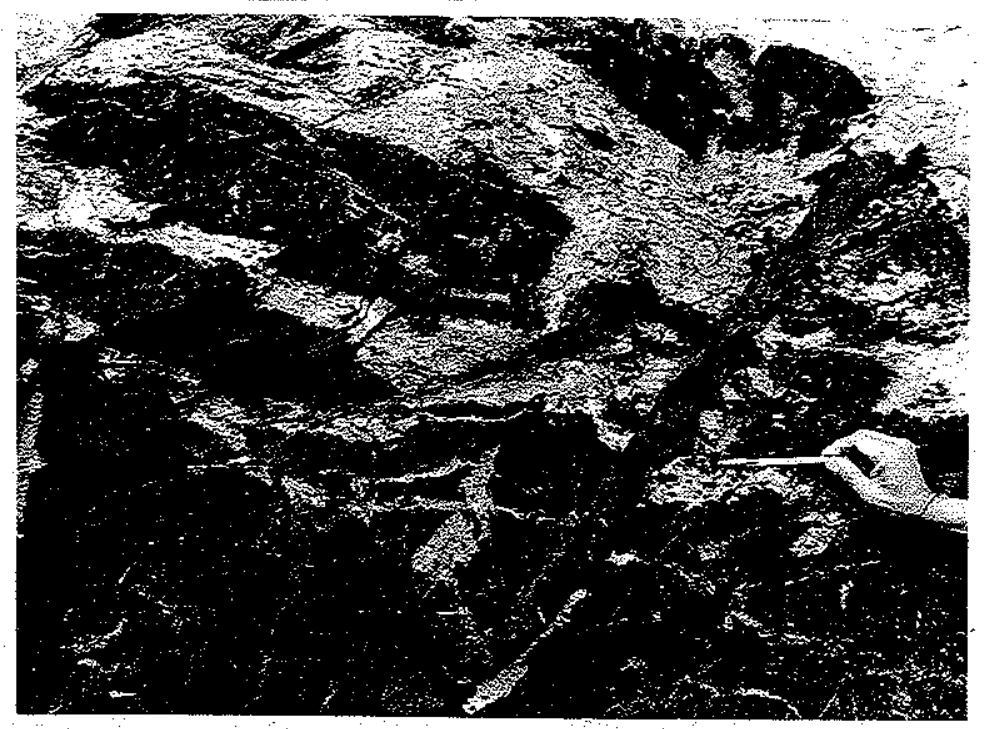

Foto 49

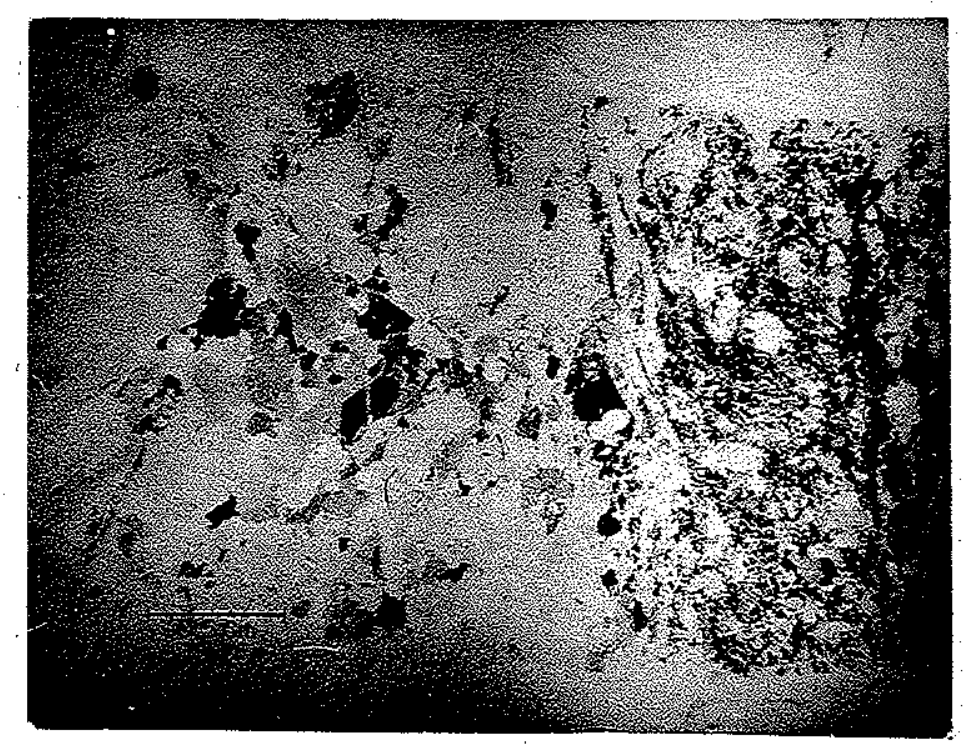




\section{MAPEAMENTOS SISTEMÁTICOS NA REGIĀO DO}

\section{LINEAMENTO DE ALÉM PARAÍBA}

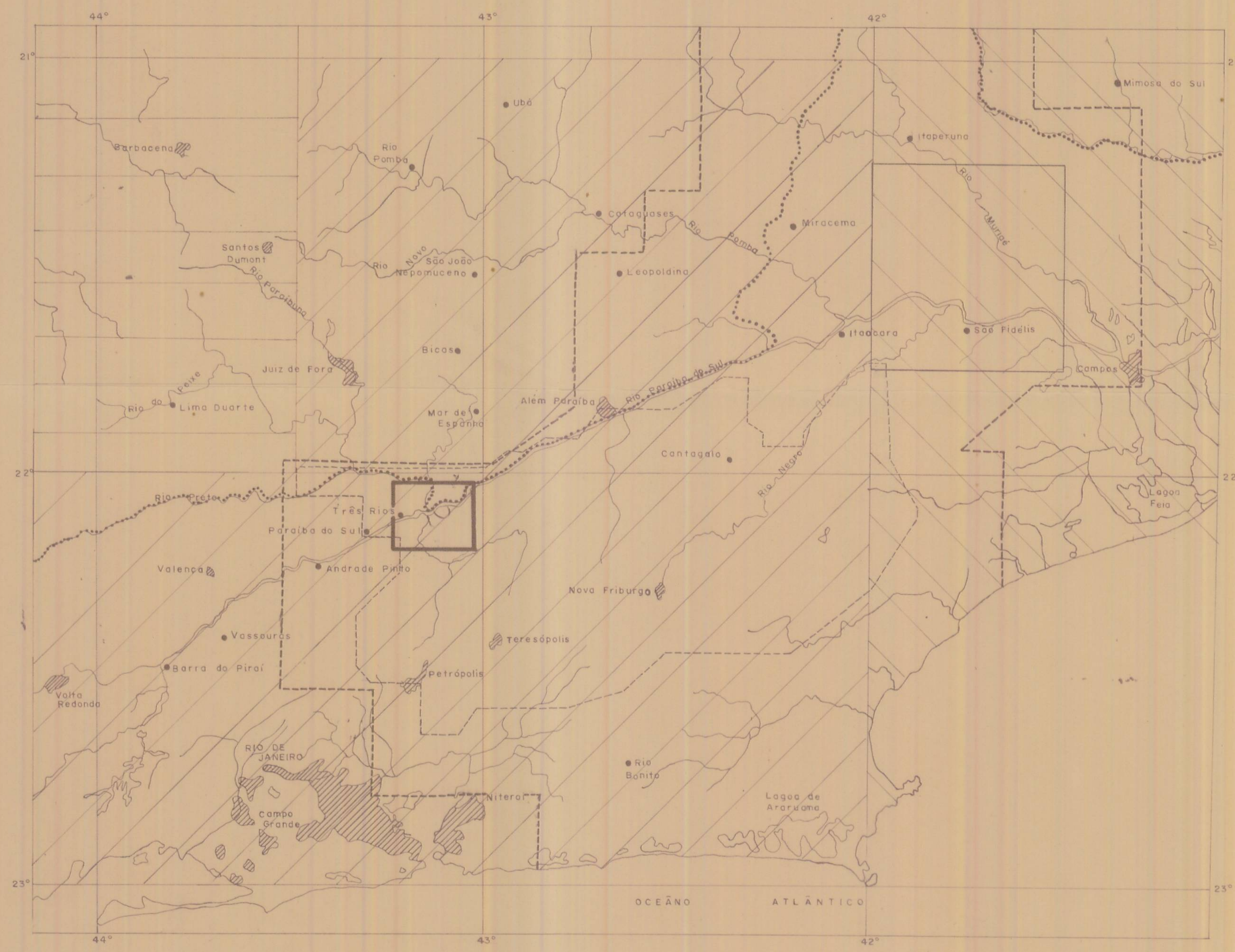

LEGENDA

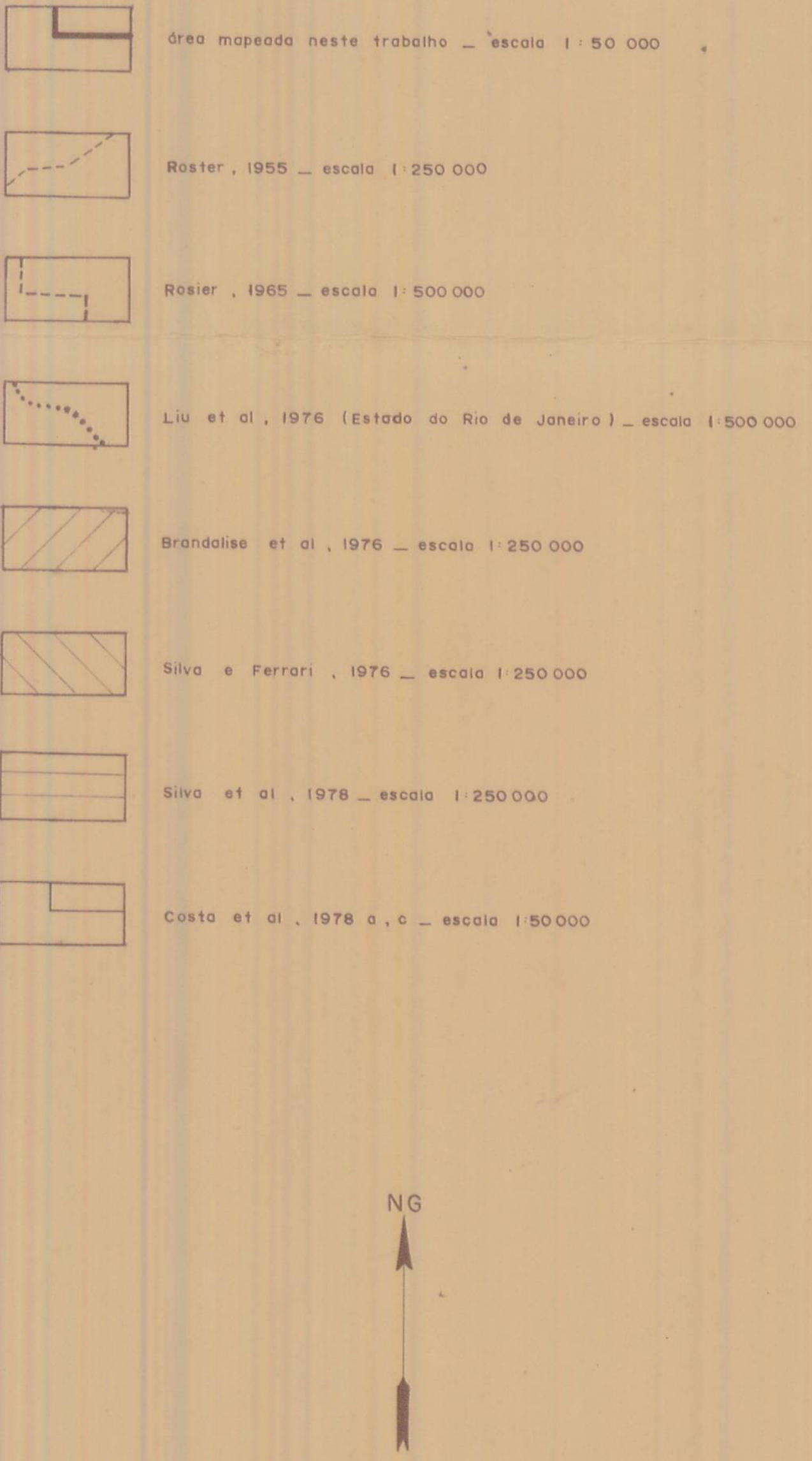

ESCALA - 1:1000000

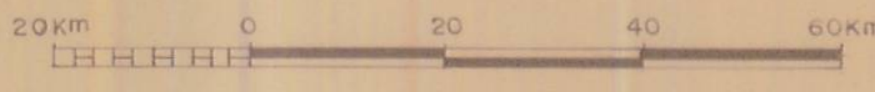




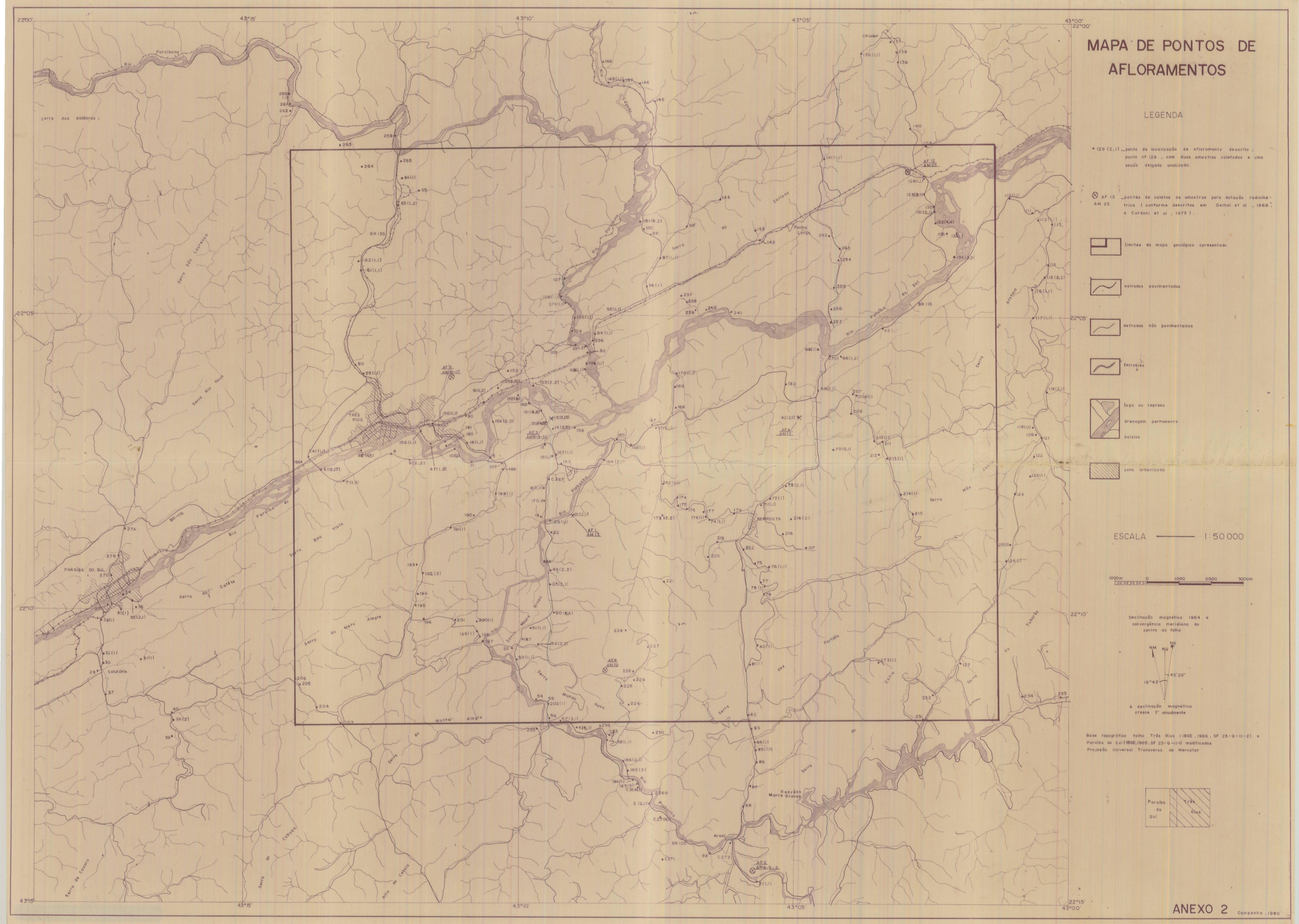




\section{ESBOÇO GEOLÓGICO ÁREA DE TRÊS RIOS}

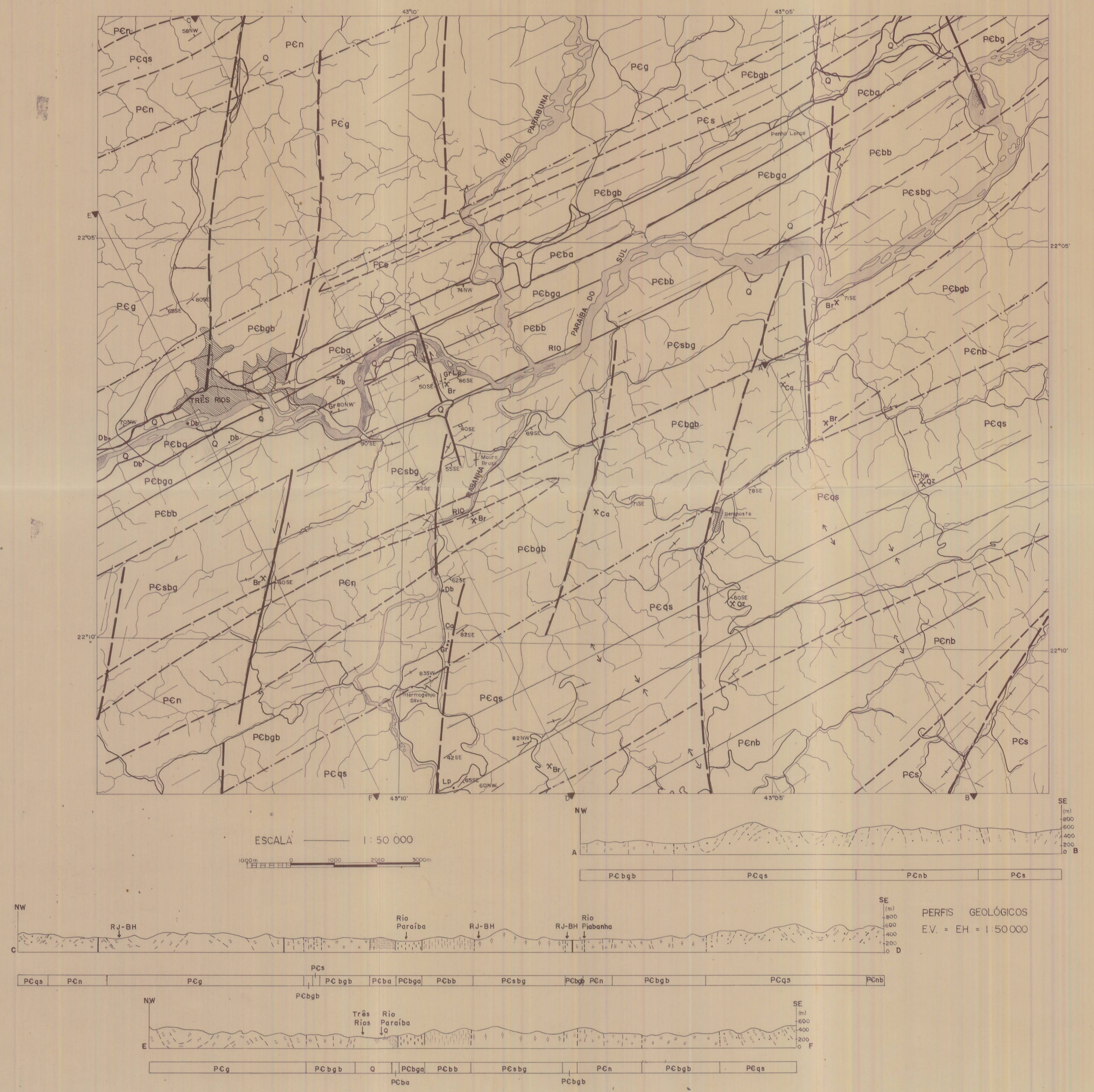

LEGENDA

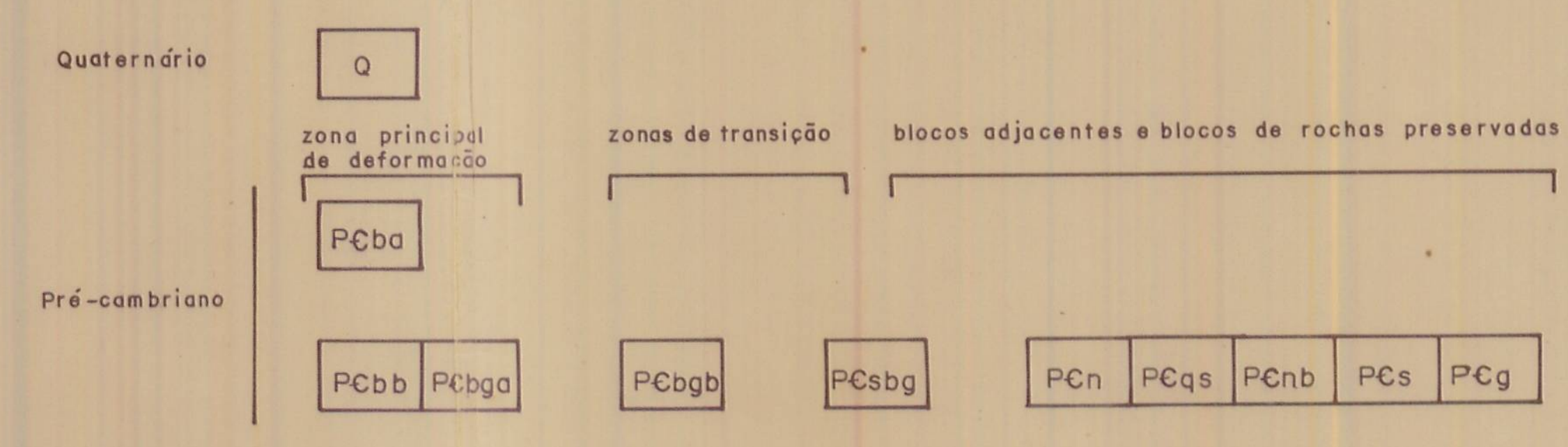

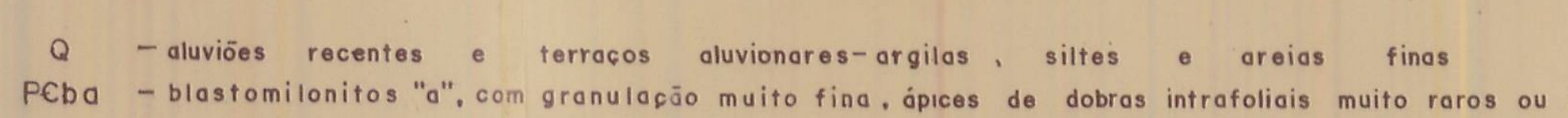

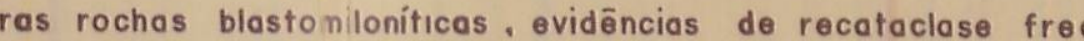

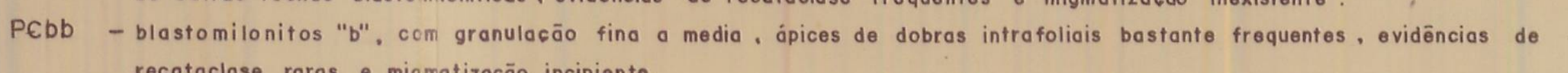

Pégga - milonito- gnisses " a",

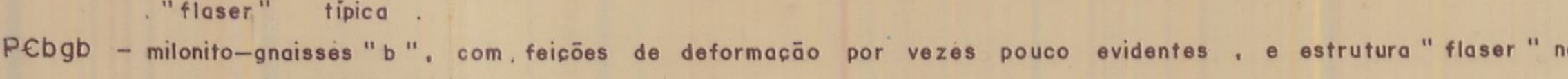

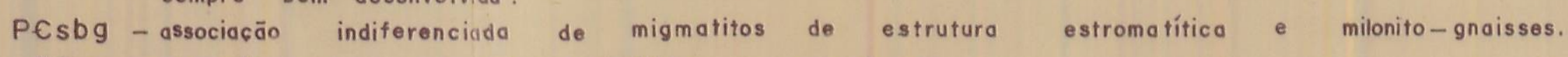

PEqS - migmotitios com estrutura estrometitica

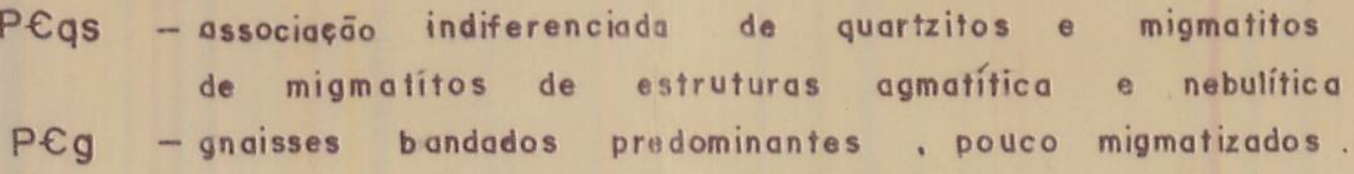

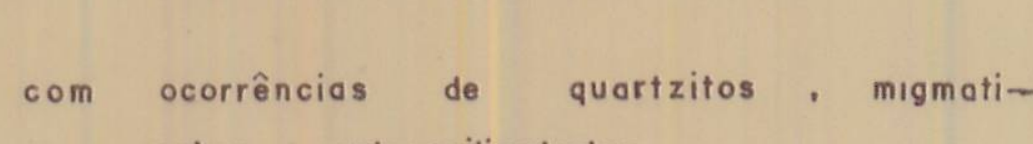

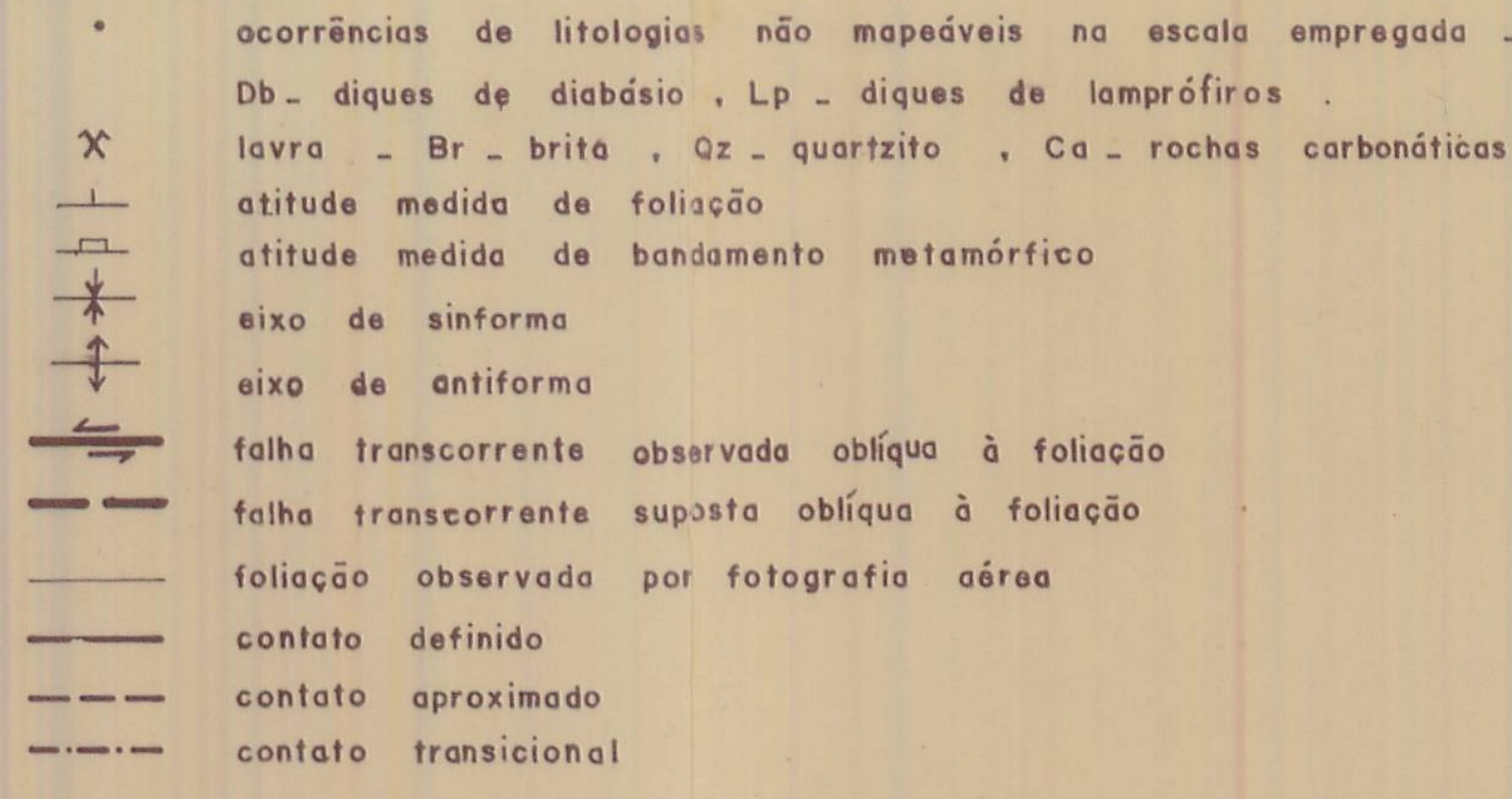
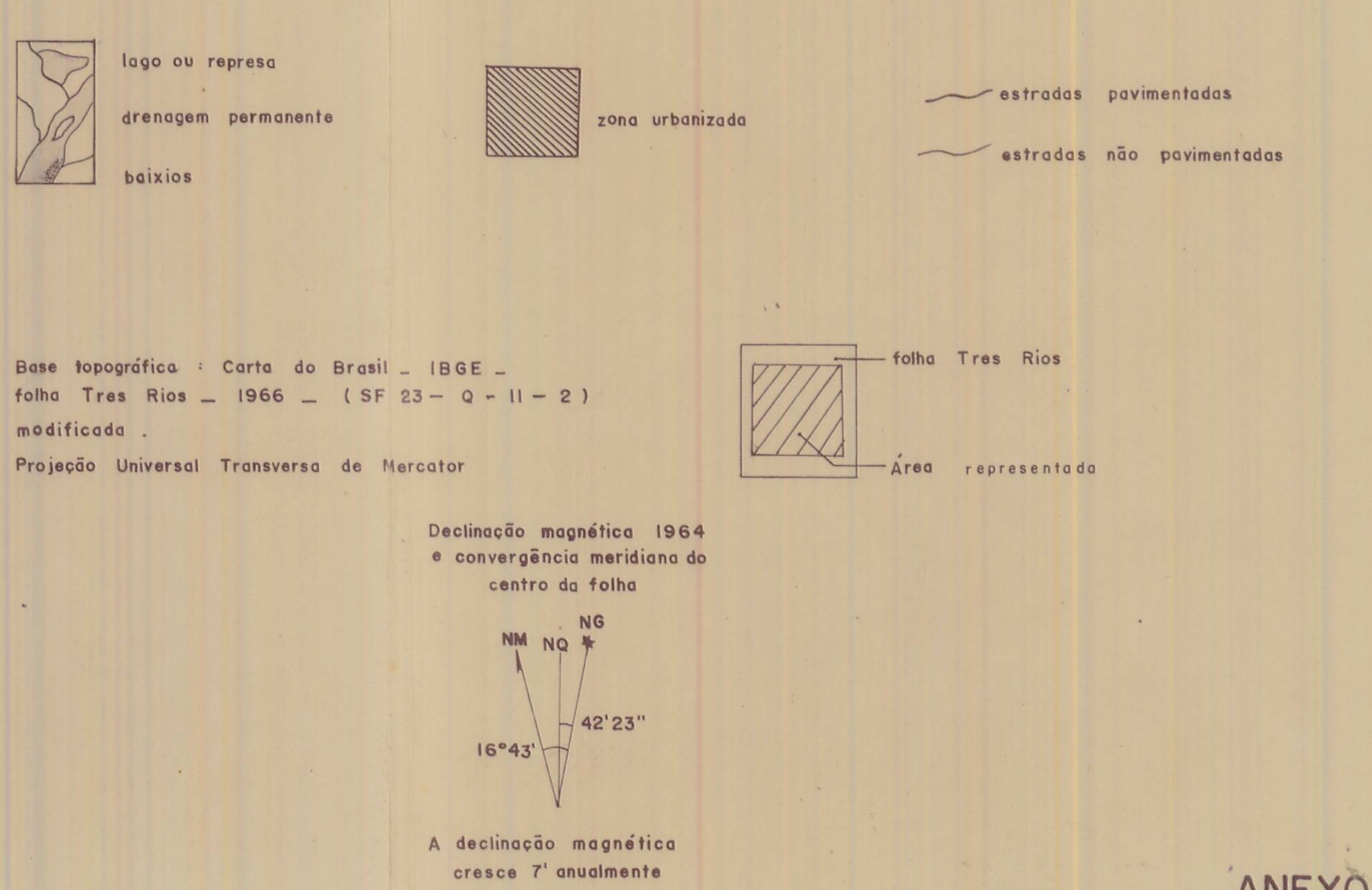
MAPA DE LINEAMENTOS DE IMAGENS LANDSAT - I

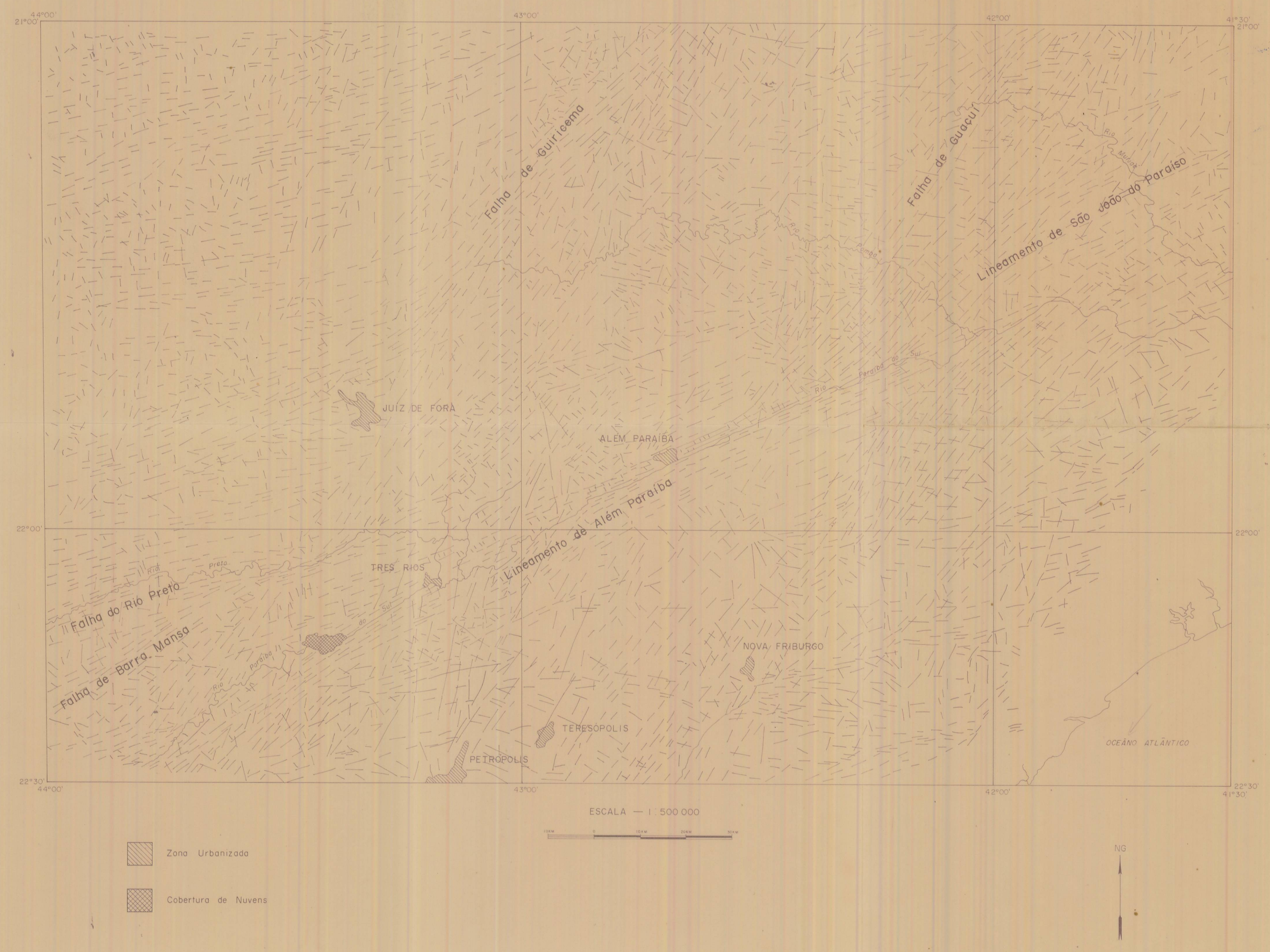

